\title{
UNA COEXISTENCIA CONFLICTIVA: MUNICIPIOS REALENGOS Y SEÑORÍOS DE SU CONTRIBUCIÓN GENERAL EN LA VALENCIA FORAL
}

\author{
David BERNABÉ GIL
}

Universidad de Alicante

\section{PARTE PRIMERA: EL REINO DE VALENCIA}

De entre las múltiples vertientes que presenta el régimen señorial valenciano, una de las menos conocidas es, sin duda, la que hace referencia al alcance real de las jurisdicciones señoriales, tanto en sus relaciones con las propias comunidades de vasallos como, de forma muy especial, en las mantenidas con otras instancias externas. Habiéndose centrado el interés historiográfico, además, en los elementos que conforman las relaciones entre señores y vasallos, con evidente predominio de los de carácter socioeconómico -como las formas de extracción del excedente, la composición de la renta, la distribución de la propiedad o, en un marco conceptual más amplio, los condicionantes del crecimiento en el seno de una economía señorial-, apenas se ha profundizado en las variadas implicaciones derivadas de la inevitable inserción del núcleo señorial en el complejo entramado jurídico-institucional, más amplio, propio del Antiguo Régimen. (1)

Como es sabido, en ese entramado de instancias de poder externas al señorío ocupa un lugar sobresaliente, por su alcance general y por su creciente consolidación, la administración real, en sus distintos niveles. Pero no siempre se tiene suficientemente en cuenta que un buen número de señoríos valencianos -aunque no los más extensos y populosos- estaban adscritos, además, a un marco urbano de realengo o quedaban supeditados a otras jurisdicciones señoriales de rango superior. Probablemente el caso más paradigmático a este respecto sea el de los señoríos alfonsinos, pues, al no gozar sus titulares de la alta jurisdicción criminal, las atribuciones correspondientes a esta última eran ejercidas por los titulares de la demarcación en la que se inscribían, fueran villas o ciudades de realengo, fueran señores 
baronales. (2) Caso no exactamente coincidente con el anterior, aunque ambos se entrecruzan en muchas de sus manifestaciones, es el de los señoríos -baronales, alfonsinos y de jurisdicción civil- enclavados en los términos generales o general contribución de los principales municipios de realengo, cuya importancia tampoco cabe desdeñar toda vez que su número bien pudo sobrepasar el centenar.

El abigarrado proceso de configuración de las estructuras territoriales y jurisdiccionales en el Reino de Valencia, consecuencia de la difícil armonización de los intereses representados por la Corona, el mundo urbano y los señores, habría propiciado, en efecto, una compleja yuxtaposición de derechos que, en determinadas ocasiones, parece enturbiar la tradicional dicotomía entre realengo y señorío. Es lo que ocurre, como se verá a continuación, con ciertas situaciones planteadas en los términos municipales de las ciudades de Játiva, Orihuela, Alicante, la propia Valencia, y de algunas villas, también realengas, como Alcira, Morella, Penáguila, Murviedro. Ya en época medieval, ante la doble necesidad de afianzar la jurisdiccción y el patrimonio real, como necesario contrapeso frente a las exigencias nobiliarias, y de vertebrar el territorio en torno a unos núcleos capaces de asumir determinadas funciones rectoras, las principales entidades de poblamiento fueron erigidas en cabezas de demarcación, mediante la asignación de un amplio término municipal y la concesión de amplias atribuciones jurisdiccionales. Los términos así constituídos eran conocidos como general contribución y solían abarcar diversos núcleos de poblamiento menores, algunos de los cuales permanecieron bajo jurisdicción real, mientras que otros quedaban sometidos a jurisdicción señorial.(3) También los hubo -de uno y otro signo- que desaparecieron con el tiempo; y no faltaron los que surgieron en fechas tardías, fundamentalmente en virtud de colonizaciones alfonsinas. (4) De un modo u otro, sin embargo, todos ellos mantenían vínculos de dependencia con respecto a la cabecera municipal, lo cual originaba situaciones potencialmente conflictivas.

En el caso de las aldeas realengas, aquéllas que destacaron por su desarrollo demográfico y económico consiguieron alcanzar, a partir del reinado de Felipe II, importantes cotas de autonomía mediante la adquisición a la Corona del privilegio de universidad; e incluso la plena emancipación, si conseguían acceder a la condición de villazgo. (5) Los núcleos señoriales, sin embargo, aunque partían de una situación jurisdiccional comparativamente más favorable que los anteriores -incluso cuando no ostentaban la baronal-, vieron algo más limitadas, por lo general, sus perspectivas de segregación legal. Las limitaciones que atenazaban el desarrollo del poder señorial en el marco urbano derivaban, no tanto de supuestos obtáculos para obtener o -en caso de que ya lo poseyeran- hacer valer la alta jurisdicción, cuanto de la discutida insuficiencia del título jurisdiccional, cualquiera que fuese su rango, para extraer de él consecuencias emancipadoras de otro orden, especialmente en el plano fiscal y en el de ciertos derechos territoriales. Como, por añadidura, los títulos de universidad y villazgo otorgados a las aldeas realengas sí contemplaban la ruptura de tales vínculos de dependencia, es posible que la antigua pugna que venían manteniendo señores y municipios matrices en tomo a determinados derechos cobrase renovado ímpetu a medida que se desarrollaba el proceso disgregador protagonizado por aquéllas. (6) 
De entre los diversos derechos que fueron objeto de litigio entre las cabeceras municipales y los señoríos de su general contribución, parecen ocupar un lugar destacado, a juzgar por la reiteración con que se plantean ante los tribunales, los relacionados con la obligación de estos últimos en el pago de los impuestos municipales establecidos por las primeras, así como los relativos al libre uso y aprovechamiento de pastos y amprius en territorio señorial; además, lógicamente, de los que tuvieron como epicentro el ejercicio de la jurisdicción criminal. Y, por supuesto, tampoco faltaron disputas en torno a otras cuestiones, como la jurisdicción sobre las aguas de riego, el alcance de las disposiciones urbanas sobre abastecimientos, o la propia delimitación territorial de los domininios señoriales.

A diferencia de lo ocurrido en el caso de las universidades y villas realengas, la conflictividad generada por los señores en torno a aquellas cuestiones -y otras afines- solía resolverse, al parecer, de forma algo precaria y, en muchas ocasiones, contradictoria; debido, entre otras razones, a la variedad de circunstancias que podían concurrir en cada caso concreto y a la ausencia de una normativa al respecto suficientemente clara y de aplicación general. De ahí que, para valorar convenientemente el desarrollo y los resultados de esa pugna resulte imprescindible acudir a la jurisprudencia, más que a los principios generales del derecho foral -o incluso a los tratadistas de la época-, y tratar de averiguar las situaciones de hecho, sancionadas a veces por la costumbre $y$, en definitiva, por la correlación de fuerzas existente en cada momento entre las partes en litigio.

Al margen de las peculiaridades locales y a pesar de que las investigaciones en este sentido no se han prodigado lo suficiente, las modalidades que presenta esa conflictiva coexistencia entre cabeceras municipales y señoríos de su general contribución derivan, en última instancia, de la consideración de éstos últimos como aldeas y "carrers" de las primeras. De esta consideración, que los municipios fundamentaban en antiguos privilegios de concesión territorial y jurisdiccional, generalmente anteriores a las configuraciones señoriales, pretendían deducir una serie de consecuencias, de entre las que sobresalen las siguientes:

a) La consideración de vecinos del municipio matriz para los vasallos de señorío.- Mientras ello se tradujera en el consiguiente derecho a gozar de los privilegios y franquicias fiscales obtenidos de la Corona por la cabecera municipal, llevase incorporado la capacidad de acogerse a cualquier tipo de proteccionismo económico desplegado por ésta, o conllevara la posibilidad de tener representación en determinados órganos del gobierno urbano; la mayor parte de los señoríos quizá no tuviera inconveniente en suscribir tal interpretación. Actitudes algo distintas debieron mostrar, sin embargo, cuando, en contrapartida a esos beneficios, se les instaba a cumplir con las obligaciones -fiscales, militares, etc- inherentes a la condición de vecinos.

b) El ejercicio de atribuciones jurisdiccionales sobre los señoríos de su general contribución.- En el caso de los señoríos alfonsinos, por ejemplo, no siempre se respetaron las competencias reservadas por el fuero de 1329 en materia de justicia, destacando especialmente los conflictos planteados en Morella. En Cortes de 1626 
el tema, que venía coleando desde época medieval, aun estaba pendiente de resolución, pues -según expresaba el brazo militar-

"en los llochs que estan dins los termens generals de la vila de Morella, com son Boxar, La Pobla, Castell de Cabres, Ballestar, y los demés que son propis del Abat y Convent de Benifaça, lo lloch de Herbes Iussans, y los llochs de Ortells, y la Tolodella, Villores, y Caranyera (...) pretenguen los de Morella impedir als senyors de dits llochs lo exercici llibero de la dita jurisdictio Alfonsina, y retenintse la mitat de les dites penes pecuniaries e impedintlos encara tenir costells eregits (...) y en raho de aço los moguen diversos plets, fundantlos en pretesos privilegis que dihuen tenir".(7)

La usurpación del derecho a la mitad de las penas pecuniarias que los fueros otorgaban a los señores alfonsinos ya había sido denunciada, en el caso de Morella, en las Cortes de $1547 ;(8)$ y no parece que fuera una práctica exclusiva de este ámbito territorial. También en la Encomienda de Orcheta, de la Orden de Santiago, cuya jurisdicción suprema recaía sobre el Justicia de Villajoyosa, éste oficial solía apropiarse "les composicions que conforme fur deu partir, y de altres penes, ab lo Justicia de Orcheta que tene la Jurisdicció Alfonsina”.(9)

Tampoco en términos de Játiva los señores alfonsinos -que superaban la treintena- consiguieron ver reconocidas todas sus atribuciones jurisdiccionales. En 1618 una sentencia de la Real Audiencia de Valencia, con votos del Consejo de Aragón, pronunciada en contra de los titulares de Bellús, Corberá, Rotglá, Ayacor, Benisuera y Sempere, reconocía -entre otras importantes facultades urbanas- el derecho que asistía a los oficiales de la ciudad -incluído el justicia de trescientos sueldos- de poder entrar en dichos señoríos con sus respectivas insignias de mando para realizar ejecuciones, y utilizar "verbis imperativis \& non deprecativis nec subsidiariis" al dirigirse a los oficiales de los mencionados señorios.(10) Que no se trataba de una situación aislada -ni, menos aun, irrelevante- lo prueba las quejas expresadas en las Cortes de 1626 por los titulares de La Granja, LLansol, Novelé, LLanera, Carbonell, Cayrent, Genovés, LLoc Nou d'En Fenollet, Vallés, Sorió,

\footnotetext{
"y altres...perque lo Iusticia civil de dita ciutat de Xativa se vol entremetre en les causes civils dels dits llochs, y lo Iusticia criminal en los casos criminals, que no enclohuen pena de mort natural, o civil, ni mutilacio de membres; y encara atenten escriure preceptivament, y no requerint, com se ha, y deu fer; y tambe lo Mustaçaf de dita Ciutat vol donar pes, y mesura en dits llochs, y sos territoris, y executar penes al modo dels establiments de dita Ciutat. Tot lo qual es directament contra lo dit fur de la jurisdictio alfonsina".(11)
}

Pero las divergencias sobre los límites precisos que este nivel jurisdiccional imponía a los oficiales setabenses dificilmente podían quedar resueltas mediante fuero, de modo que los problemas -seguramente heredados de época medieval- continuaron a lo largo del XVII, involucrando también a otros señoríos: Torrent, Anahuir, Miralbó, LLorís, Cerdá, Torre dels Frares, Torrella y LLanera, entre ellos.(12)

La forma de realizar las ejecuciones y de dirigirse a los justicias ordinarios de los señoríos alfonsinos también fue objeto de litigio en el caso de la ciudad de 
Valencia. Así quedó de manifiesto en las protestas presentadas por el Cabido de la Catedral de dicha ciudad, como señor alfonsino de Burjasot y Benimaclet, en Cortes de 1542, pues las ejecuciones por deudas de sus vasallos

"no la fan, ni la volen fer ab letra subsidiaria tramesa al jutge ordinari dels dits lochs,
sino que trameten un porter, o missatge dels dits tribunals (de la ciutat), e aquell dit
porter, missatge o verguer de dret en dret sen va a la casa e habitacio del vasall dels
dits lochs, o del altre de aquells y executa, e o trau penyores de la casa de aquell, lo
que es contra fur del dit regne, per ço com per furs del dit regne es dispost que los
lochs que son poblats de quinze cases en amunt tots tenen jurisdictio civil ordinaria \&
etiam tenen lencohercio (sic)".(13)

Y no muy distintas fueron las peticiones expresadas décadas más tarde por el estamento eclesiástico, pues, teniendo la Orden de Montesa

"la jurisdiccio civil, y criminal vulgarment dita Alfonsina, en los llochs del Batliu de Moncada, situats dins los termens generals de la ciutat de Valencia, y dins los llimits de la dita jurisdiccio, no puixa lo justicia de la dita Ciutat fer citacions, trametre Corts, ni enviar ministres, sino en cas de renunciació de propri for; y encara en estos casos deu ferho mijançant lletres in iuris, \& justitiae subsidium, y no ab lletres imperatives, ni preceptives. Y lo mateix succeheix en altres llochs que son de persones, $O$ comunitats del Estament Eclesiastich".(14)

Por lo general, la respuesta real a este tipo de quejas expresadas en Cortes no podía resolver el contencioso planteado, pues solía reducirse a ordenar que se observaran los fueros al respecto o la costumbre, cuando no se remitía a lo que declarasen los tribunales, instado el proceso.

Ante el carácter frecuentemente litigoso de algunas de sus atribuciones en materia de justicia, no fueron pocos los señores alfonsinos que trataron de obtener de la Corona la alta jurisdicción criminal, al objeto de incrementar y consolidar el control sobre sus dominios y, en la medida de lo posible, evitar los continuos pleitos con las cabeceras municipales. Tales eran, precisamente, las razones aducidas en las Cortes de 1604 por los señores alfonsinos de Canet -en término de Morvedre-, Benizano en término de LLiria-, Alginet, Rafelbunyol y Maçalfaçar -en término de Valencia-, al solicitar de la Corona "lo exercici de la suprema jurisdictio titulo gubernatorio".(15) Y una petición similar presentó en las Cortes siguientes el señor de la Encomienda de Orcheta -en término de Villajoyosa.(16) Este tipo de asambleas no era, sin embargo, el marco apropiado para atender tales pretensiones, sólo al alcance, además, de quienes pudieran presentar una buena relación de méritos y un cuantioso servicio en dinero; pues podía propiciar también -como así sucedió- peticiones en sentido contrario por parte del estamento de las ciudades.

En las Cortes de 1626, en efecto, el brazo real solicitó del Monarca "sia servit de no concedir semblants concessions de jurisdiccio, que en efecte, y en veritat encara que vulla colorarles ab lo dit titol de gubernatorio nomine, son aliennacions y separacions verdaderes del dit Real Patrimoni".(17) Naturalmente, un Monarca siempre falto de recursos y sensible a los servicios prestados no podía comprome- 
terse a tanto, de modo que continuó favoreciendo a algunos señores alfonsinos con este tipo de prerrogativas, tal como había hecho su antecesor, en 1604, en beneficio de D. Pedro Franqueza, al otorgarle la alta jurisdicción criminal sobre Villafranqueza, en término de Alicante.(18) Así, con posterioridad a 1626, Felipe IV otorgó jurisdicciones gubernatorio nomine, entre otros, al señor de Erbés, en término de Morella,(19) a los de Benasau, Alcoleja, Beniafé y Benifallim, en término de Penáguila,(20) amén de los que se mencionarán más adelante, en término de Orihuela. Es por ello que en 1645 el brazo real volviera a reiterar su petición de años atrás, alegando ahora -significativamente- la necesidad de evitar los costosos pleitos y litigios que solían suscitarse entre los beneficiarios de aquéllas y las cabeceras municipales.(21)

Lejos de propiciar situaciones menos conflictivas, el ejercicio de la jurisdicción baronal por parte de los señores también debió suscitar enconados litigios en materia de justicia, especialmente si los títulos acreditativos no eran suficientemente explícitos o tenían un origen tardío y, en consecuencia, vulneraban derechos adquiridos. Así ocurrió, por ejemplo, con los prodigados entre la ciudad de Játiva y algunas baronías -Antella, Barcheta, Cotes, Sumacárcer-;(22) o los habidos entre la villa de Alcira y la baronías de Montortal, Benimuslem, Alberique, Carlet, entre otras.(23) Y tampoco faltaron en término de Morvedre, con más de una veintena de baronías.(24) Junto a la exhibición de todos aquellos instrumentos probatorios que pudieran apoyar sus pretensiones, las cabeceras municipales solían invocar como argumento principal el menoscabo de la jurisdicción real que se seguiría de no atenderse sus demandas. De ahí que consiguieran atraer, con cierta frecuencia, a los procuradores patrimoniales de la Corona como parte interesada en las instancias judiciales. Cosa bien distinta era, no obstante, que consiguieran embarcar a la Monarquía en una política de reincorporación jurisdiccional de gran alcance. Algunos conatos en esta dirección, como los ensayados por Fernando el Católico, no pasaron de simple amenaza. Y muy particularmente la orden cursada al estamento militar valenciano en 1483 para que se mostrasen

"tots los titols ab que posseixen e usen de les jurisdiccions de mer imperi en los lochs, viles e castells que tenen e són situats dins los termens de les ciutats e viles nostres reals".(25)

Por su parte, los barones tampoco andaban faltos de apoyo en los órganos de la administración real, de los cuales, a veces, incluso llegaban a formar parte. Una solicitud de incompatibilidad a este respecto, presentada por el estamento real en Cortes de 1547 -"que ningun baró o señor de lloch, tenint terme dins terme de universitat e vila Real, y fills de aquells, no puixen tenir o exercir offici Real de qualsevol qualitat e condició sien en aquella o en aquelles universitats, com axi convingue al benefici del patrimoni Real de Sa Magestat e de les dites universitats(26)-, no evitó que tales situaciones continuaran prodigándose.(27) Y, de hecho, las concesiones de mero imperio gubernatorio nomine llegaron a ser equiparadas por la doctrina con la creación de un oficial real.(28) 
Por otro lado, el resultado de esta conflictividad, aun mal conocida, aunque salvaguardara la titulación nominal del rango jurisdiccional reclamado por los señores, parece que no siempre clarificó lo suficiente algunas de las competencias concretas que la dotaban de contenido efectivo y determinaban su alcance real. Así, no es raro encontrar concesiones señoriales de la alta jurisdicción criminal en términos de ciudades y villas reales -Valencia y Murviedro, por ejemplo- en las que se hace reserva expresa de la potestad de ejecutar la pena de muerte o se prohibe eregir horca,(29) atribuciones que comúnmente eran consustanciales a dicho rango.

c) La facultad de obligar a los vasallos de señorío a contribuir en los impuestos municipales establecidos por la cabecera.- En los conflictos por este motivo, el nivel jurisdiccional alcanzado o pretendido por los señores parece ocupar una posición secundaria frente a otras cuestiones, más polémicas, como el tipo de contribuciones y las modalidades de recaudación. Aunque es arriesgado establecer principios de aplicación general sobre el tema, debió gozar de amplia aceptación el criterio de obligatoriedad contributiva en los antiguos impuestos destinados a la conservación y reparación de las murallas urbanas -conocidos como murs y valls-; tal como parece deducirse de ciertas noticias referentes a Játiva, Alcira, Morella y Valencia.(30) En el término de Játiva no faltaron, sin embargo, pleitos al respecto, en 1620 y 1624 , contra algunos señores que oponían resistencia a su cobranza.(31) Y en el caso de Alcira, donde ya en el siglo XIV los señores consiguieron -tras varios conflictos- que se fijara a sus dominios un cánon perpétuo e invariable,(32) tampoco fueron desconocidos los intentos de evasión, tal como quedó reflejado en las Cortes de 1626.(33) Años más tarde eran los señoríos de Morella los que se negaban a aceptar un incremento de las contribuciones ordinarias que se venían recaudando para reparación de murallas.(34)

De modo no muy distinto, en aquellas cabeceras municipales que, sin gozar de exención, habían transformado la peyta real en un tributo municipal mediante su encabezamiento a perpetuidad en una cuantía fija,(35) los repartimientos para su cobro también parecen extenderse al dominio señorial -casos de Játiva,(36) Alcira,(37) Penáguila,(38) Morella;(39) pero no así Valencia, Alicante y Orihuela, por estar exentas. En el caso de las baronías más antiguas -las del término de Morvedre, por ejemplo-(40) es posible que las peytas reales hubieran sido transferidas a los señores, escapando así su recaudación a las cabeceras municipales. Pero es improbable que ocurriera lo mismo con las concesiones tardías de la jurisdicción suprema -no precisamente las menos conflictivas-, debiéndose entender que, a estos efectos, dichos dominios permanecían en la situación anterior, equiparable a la vigente en los señoríos alfonsinos y, en consecuencia, sujetos a peytas en la medida en que también lo estuviera la propiedad realenga del municipio matriz.

Otro tipo de contribuciones municipales, como las sisas vecinales sobre el consumo y los intercambios, también trataron de recaudarse en los núcleos señoriales, a veces quizá de forma sistemática. En la mayoría de los casos, sin embargo, debió depender del destino concreto que hubiera determinado su aplicación -tal como parece sentar la jurisprudencia-,(41) provocándose el conflicto cuando los señores 
se consideraban ajenos al motivo aducido. Condición acostumbrada en Játiva y, probablemente, en Morella para poder obligar a los señoríos en el pago de determinada sisa era, asímismo, la de haberse establecido por el órgano correspondiente -el consell urbano-, previa convocatoria a los señores.(42) La conflictividad generada en torno a todas estas contribuciones también se debió, a veces, a las tentativas de la cabecera municipal para incrementar las recaudaciones obtenidas de los señoríos, en el caso de que éstos hubieran concertado sus obligaciones fiscales en una cuantía fija que, con el tiempo, pudo devenir en simbólica.(43)

Por todos los motivos mencionados, la resistencia a contribuir y las pretensiones en sentido contrario originaron litigios de diversa índole, cuya resolución no siempre dependía del nivel jurisdiccional alcanzado por los señores. Consciente de ello, en las Cortes de 1604 el brazo militar trató de arrancar a la Corona una declaración que garantizara una congelación de los impuestos urbanos para, al menos, los señoríos de jurisdicción suprema, sin plantear siquiera una exención con carácter retroactivo. Lo que se pedía, concretamente, era que "los vasalls dels tals Barons no tinguen obligacio alguna de contribuhir en les taches, imposicions, ni altres carrechs que de aci avant se imposaran en les dites ciutats y viles Reals". Pero ni siquiera ésto le fue concedido, pues -como era habitual en este tipo de peticiones- el Monarca se limitó a responder que "se guarden en aço los furs y privilegis del Regne, y lo que esta dispost de justicia".(44) Dada la escalada de la fiscalidad municipal que estaba comenzando a generarse en todo el Reino, los conflictos entre señores y cabeceras municipales sobre las obligaciones al respecto habrían de resultar, pues, inevitables.

d) la comunidad de pastos y derechos de amprius -cazar, coger frutos silvestres, hacer leña, cal etc.- En general, los litigios suscitados en torno a los derechos de uso y aprovechamiento de las hierbas y montes señoriales enclavados en los términos de villas y ciudades reales parecen responder a una doble tipología, aunque ambas modalidades no siempre aparezcan separadas con suficiente nitidez en los procesos judiciales. Por un lado, nos encontramos con ciertas pretensiones de las cabeceras municipales contrarias a la facultad señorial de arrendar las hierbas de sus dominios. Esta reivindicación urbana, quizá más difícil de hacer prevalecer en las baronías, podría resultar un tanto sorprendente si se atiende a la letra de lo dispuesto en un fuero de 1403 -nunca derogado antes de 1707-, en que el Rey Martin dispuso

"que alguns havents lochs en lo dit regne, en térmens de ciutats e viles reyals, no sien empatxats vendre llurs erbatges; e mana a les dites ciutats e viles que no prohibesquen o penyoren los compradors de tals erbatges, romanint, emperò, a les dites ciutats e viles ses pastures o amprius acostumats e pertanyents, en los quals no puxen ésser empatxats per los dessús dits".(45)

Pero, no obstante la aparente claridad de la disposición foral, en 1621 aun podemos encontrar a la ciudad de Játiva pleiteando con 17 señoríos

"sobre la provisió en que está la Ciutat de vendre y arrendar les herbes y pastures dels termens y realengos de Xativa y territori dels llochs de son terme general sens permetre que los seus senyors puixen arrendarlos"..(46) 
Ciertamente, no debió ser muy frecuente en el contexto regnícola la proliferación de litigios de esta naturaleza, aunque podrían mencionarse casos similares que permiten cuestionar su carácter supuestamente excepcional: en Cortes de 1626, por ejemplo, era la villa de Alcira la que trataba de impedir el arrendamiento de las hierbas señoriales al titular de Masalavés.(47)

Pero, dada la difícil cobertura jurídica a las pretensiones urbanas en el sentido indicado, no debió ser éste el derecho más controvertido. La mayor parte de los litigios sobre el uso y aprovechamiento de pastos y amprius parecen plantearse en torno a la supuesta facultad de los señores para prohibir la entrada en sus dominios a cualquier vecino del término general y, muy en particular, al abastecedor de las carnicerías urbanas.(48) Tal parece ser el motivo de los innumerables pleitos sobre hierbas señoriales habidos en Játiva;(49) y tampoco en término de Alicante faltaron litigios de esta naturaleza, especialmente con el señor de Agost.(50) Estas prohibiciones de uso y la consiguiente potestad señorial de penalizar a los infractores no estaban respaldadas precisamente por el mencionado fuero de 1403. Y tampoco por el cúmulo de disposiciones contenidas en la Sententia executoria dels Emprius de la Ciutat de València de las mismas cortes, que, con las confirmaciones y adiciones subsiguientes, constituyó pieza clave en el ordenamiento foral sobre el tema.(51) Dicha sentencia excluía unicamente del libre uso vecinal el denominado boalar señorial, pero con la condición de que su titular lo reservara de forma gratuita para el ganado de labor y del abastecimiento de la carnicería señorial, sin posibilidad de arrendarlo.(52)

En realidad, la única disposición foral que respaldaba claramente la plena privatización, con carácter excluyente -esto es, el derecho privativo y prohibitivo-, de las hierbas señoriales se remontaba a 1238 y establecía como condición la posesión de privilegio expreso de dehesa y vedado.(53) En ausencia de este instrumento legal, sin embargo, tampoco resultaba imposible imponer de facto tales prohibiciones mediante actos positivos, siempre que no hubiera contradicción de parte y quedaran sancionados por la costumbre, hasta constituir posesión inmemorial. Y este debió ser, al parecer, el verdadero caballo de batalla en la mayor parte de los litigios suscitados.

Ciertamente, los ejemplos mencionados hasta el momento dejan traslucir la existencia de una pugna, cuando menos latente, entre los núcleos urbanos de jurisdicción real y las entidades señoriales enclavadas en sus respectivas demarcaciones territoriales. Buena parte de las manifestaciones concretas de esas tensiones parecen presentar, además, similitudes de interés en ámbitos y momentos diversos. Pero las referencias manejadas hasta el momento no aclaran gran cosa acerca de las vicisitudes que acompañaron el surgimiento de los diversos conflictos y apenas permiten entrever sus resultados. Se hace necesario, por tanto, un análisis algo más detenido, a partir del estudio concreto de los diversos ámbitos territoriales -términos generales- donde se detectan los problemas mencionados. La casuística que se presenta a continuación, referente a la ciudad de Orihuela, quizá contribuya a clarificar determinados aspectos de esa conflictiva coexistencia. 


\section{PARTE SEGUNDA:}

\section{LA GENERAL CONTRIBUCION DE ORIHUELA}

\section{La génesis de las jurisdicciones señoriales}

Aunque la contribución general de Orihuela tiene su origen en un privilegio de concesión de términos inmediato a la conquista, su delimitación territorial definitiva no se alcanzó hasta varias décadas más tarde, tras las segregaciones de Crevillente y Abanilla.(54) Desde entonces, y a lo largo de la edad moderna, los límites apenas variaron, veniendo a coincidir aproximadamente con los de la actual comarca del Bajo Segura; pero sí lo hicieron los núcleos de poblamiento y sus relaciones de dependencia con respecto al centro urbano que se erigía en cabeza de demarcación.

Tras una primera remodelación -provocada por la conquista y la subsiguiente ocupación cristiana- de las formas de habitat heredadas de la época musulmana, diversas vicisitudes posteriores debieron imprimir a determinados núcleos de poblamiento una especial inestabilidad, de hondas consecuencias sobre la configuración de la propiedad y del elemento jurisdiccional. Si, por un lado, la situación fronteriza y las operaciones bélicas desarrolladas en territorio oriolano durante los siglos XIV y XV se combinaron con las catástrofes naturales -epidemias, inundaciones- para agudizar los efectos demográficos; por otro, los cambios de soberanía sobre un territorio disputado por castellanos y aragoneses se tradujeron a veces en confiscaciones y nuevas donaciones que contribuyeron a remodelar el mapa jurisdiccional.(55) Las transformaciones concretas operadas durante ese periodo aun no son bien conocidas, pero existen indicios suficientes para tratar de dibujar la situación jurisdiccional existente, aproximadamente, a comienzos del reinado de Fernando el Católico. En esos momentos el término de Orihuela incluía cuatro aldeas de realengo -Catral, Almoradí, Callosa y Guardamar-, dos señoríos baronales -La Daya y Albatera- y un número indeterminado de señoríos y alquerías, en algunos de los cuales sus respectivos titulares quizá estuvieran en condiciones de ejercer la jurisdicción civil, pero difícilmente la alfonsina.

En las aldeas realengas -que no serán aquí objeto de mayor atención- su dependencia con respecto al núcleo urbano se expresaba fundamentalmente en la inexistencia de oficiales con jurisdicción propia pues, aunque no carecían de ellos, actuaban como lugartenientes de los de Orihuela, a cuyos titulares correspondía su nombramiento. Al no disponer de estatuto municipal independiente -con la excepción de Guardamar, que se hallaba en una situación especial-, los habitantes de estas comunidades estaban obligados a las cargas vecinales -fiscales, militares. etc.- vigentes en la ciudad, compartían el uso de amprius y aprovechamientos comunales y se beneficiaban de sus privilegios y franquicias. A finales del XVI Callosa y Almoradí conseguirán importantes cuotas de autonomía al adquirir el título de universidad, mientras que Catral, que también lo procuró, fracasó en su tentativa. Ya en 1632 Callosa obtiene la segregación plena al obtener el título de villazgo; y en 1692 hace lo propio Guardamar.(56)

De las dos baronías existentes, La Daya era un antiguo señorío cuyo titular - 
Gonçalvo Garcia- había obtenido en 1334 la jurisdicción suprema, tras haber conseguido diversas franquicias fiscales de la Corona y previa renuncia al fuero de Aragón, para acogerse al de Valencia.(57) Posteriormente, el dominio pasaría a los Masquefa, que lo poseyeron hasta bien entrado el siglo XVII.(58) También Albatera fue lugar de señorío tras la conquista,(59) pero en este caso la adquisición del mero imperio no parece que fuera alcanzada antes de 1463, en que se concedió a D. Ramón Rocafull por los servicios prestados en la contienda catalana.(60)

Otras donaciones señoriales documentadas a finales del siglo XIII y principios del XIV, como las de Cox, Redován, Algorfa y Jacarilla, corrieron distinta suerte que las anteriores, pues además de no conseguir la jurisdicción baronal, sus titulares posiblemente tampoco lograron mantener la alfonsina, en el supuesto de que hubieran llegado a ejercerla en virtud del fuero de 1329.(61) De haber estado en condiciones de acogerse en algún momento a esta disposición, sólo la despoblación posterior de estos lugares pudo privar a sus respectivos señores de dicho rango jurisdiccional. Pero no así, necesariamente, de la jurisdicción civil, pues, por fuero antiguo, ésta era consustancial a la concesión del feudo.(62) Y probablemente en situación no muy distinta, en lo que se refiere al derecho a ostentar la jurisdicción civil sobre dominios sin población estable, se hallaría a finales del XV el titular de Benferri; e incluso los de Benejúzar y Rafal, cuyos topónimos revelan, por otra parte, su antigua condición de alquerías musulmanas. En estos dos últimos casos, sin embargo, su origen señorial parece ser posterior a la primera oleada de infeudaciones, toda vez que en los primeros repartimientos que siguieron a la conquista no figuran como tales, sino que lo hacen como partidas rurales cuyas tierras fueron distribuidas en pequeños y medianos lotes. Posteriormente, quizá durante la Guerra de los Dos Pedros, debieron recomponerse los derechos de propiedad, sin que quepa descartar tampoco nuevas donaciones feudales sobre las mismas bases territoriales.(63)

Tras estas primeras etapas en la configuración del régimen señorial, caracterizadas por la concesión de infeudaciones y por la inestabilidad de los asentamientos humanos -lo que habría propiciado un proceso de concentración de la tierra o de consolidación de dominios-, a finales del siglo XV comienza a insinuarse otra fase distinta que solo cobrará impulso definitivo a lo largo del XVII. A diferencia de las anteriores, la nueva modalidad se basará en las iniciativas colonizadoras emprendidas por señores de jurisdicción civil y por grandes propietarios en el realengo que, acogiéndose al fuero de 1329 , establecerán en sus dominios un número de pobladores suficiente para alzarse con la jurisdicción alfonsina. Elemento esencial para garantizar el éxito de esta estrategia señorial será la cesión en enfiteusis de tierras y casas levantadas al efecto, con claúsulas de obligación de residencia, limitaciones a la venta del dominio útil, etc. Pero también, con tal que la situación previa no conllevara el ejercicio efectivo de algún tipo de jurisdicción inferior, el desarrollo de otras atribuciones señoriales, como la constitución de municipio orgánico mediante la creación de oficiales -justicia, jurados, etc.- y la dotación de servicios -carnicería, tienda, panadería, taberna, etc- cuya explotación se reserva el señor en régimen de monopolio. Las colonizaciones alfonsinas actúan, por tanto, como instrumento 
generador de nuevas entidades jurisdiccionales allí donde no se conocían previamente -o incrementan su rango, añadiendo la jurisdicción criminal baja, si ya se poseía la civil- y, en virtud de ello, generan nuevos municipios de derecho.

Del modo indicado se producirán, en el término de Orihuela, las colonizaciones alfonsinas de Cox (1483),(64) Redován (1491),(65) La Granja (antes de 1491),(66) Benejúzar (1607-11),(67) Benferri (1619),(68) Rafal (1636-39),(69) Benijófar (1689),(70) Jacarilla (antes de 1690),(71) Formentera (1691),(72) Molins (1698)(73) y Bigastro (1701).(74) Y, ya fuera de nuestro ámbito cronológico de referencia, las de Daya Vieja (1791)(75) y Algorfa (1790-98).(76) Tentativa similar a las anteriores, pero en este caso frustrada, fue la desarrollada en Santa Agueda en 1697, cuando ya había sido otorgada incluso la carta-puebla correspondiente.(77) Por insólito que pueda parecer, la proliferación de colonizaciones alfonsinas en fechas tan tardías no es un fenómeno exclusivo del término oriolano,(78) aunque aquí se manifieste con mayor intensidad dada la escasa densidad demográfica y el elevado índice de concentración de la propiedad de la tierra que caracterizaban un territorio que, por entonces, comprendía el sistema hidrahúlico más extenso del Reino de Valencia.(79)

Pero, siguiendo una práctica habitual en situaciones similares, durante la primera mitad del XVII la mayor parte de estos señores evidenciaron no conformarse con la jurisdicción alfonsina; de modo que aprovecharon el clima favorable al intercambio de servicios por mercedes para obtener del Monarca la jurisdicción suprema. Es lo que consigue en 1628, a título gubernatorio con carácter temporal -hasta las próximas Cortes-, el señor de Benejúzar, D. Jaime Rossell, a la sazón Lugarteniente del Gobernador de Orihuela, mediante servicio a la Corona de 1.000 ducados en plata doble.(80) Al año siguiente era el señor de Cox, D. Juan Ruiz, quien solicitaba lo mismo, ofreciendo idéntica cantidad, por lo que también se le concede.(81) En 1636 hace lo propio el señor de Rafal, D. Jerónimo Rocamora, Lugarteniente del Gobernador de Orihuela, pretendiendo además título de marqués; pero ha de conformarse únicamente con la titulación honorífica pese a su extenso y meritorio curriculum al servicio de la Corona.(82) Aprovechando las Cortes celebradas en 1645, el señor de Benejúzar, ahora Bayle General de Orihuela, ve confirmado a perpetuidad el rango jurisdiccional adquirido años atrás; aunque también pidió título de Conde, que le fue denegado, probablemente por limitar su ofrecimiento a una relación de méritos sin incluir servicio monetario.(83) Y al año siguiente era D. Francisco Maza y Rocamora, Conde de La Granja -cuyo título habia sido creado en 1628-,(84) quien accedía a la jurisdicción baronal gubernatorio nomine por 10.000 reales de plata, entre otros servicios militares, of recidos a un monarca siempre falto de recursos.(85) Otra concesión jurisdiccional, en este caso la de barón, fue otorgada en 1631 al ya mencionado D. Jerónimo Rocamora sobre La Puebla, señorío de nueva planta procedente de una segregación efectuada en el término baronal de La Daya por venta ejecutiva -lo que constituye un caso insólito en el derecho valenciano.(86)

Contrariamente a lo que se observa en la primera mitad del XVII -o, mas concretamente, en su segundo cuarto-, las concesiones de jurisdicción suprema dejan de prodigarse a finales de la centuria. De entre la oleada de colonizadores alfonsinos 
que por entonces se detecta, solo en un caso hay constancia de que se solicitara posteriormente la alta jurisdicción criminal; pero la petición no fue atendida, dada la oposición mostrada por la ciudad de Orihuela y el Procurador Patrimonial. Se trataba de la cursada en 1700 ante el Consejo de Aragón por D. Luis Togores, señor de Jacarilla, quien también pretendía privilegio de dehesa para su señorío.(87)

\section{La ciudad de Orihuela frente a las jurisdicciones señoriales}

Ante el desarrollo de ese prolongado proceso de señorialización, protagonizado fundamentalmente por el sector más dinámico de la propia nobleza oriolana, era lógico que la ciudad, como titular de la general contribución, no permaneciera impasible, dadas las implicaciones de carácter jurisdiccional, municipal y territorial que de aquel solían derivarse y la potencial conflictividad que todo ello encerraba. Los litigios entre la ciudad y los señores fueron, en efecto, numerosos y se centraron, por lo general -aunque también abarcaron otros aspectos-, en torno a las tres grandes cuestiones habituales en casos similares: el ejercicio de la jurisdicción, las contribuciones fiscales y el aprovechamiento de los pastos y amprius. Pero antes de exponer las vicisitudes y resultados de esos contenciosos, no siempre bien diferenciados en las alegaciones realizadas ante los tribunales, convendría interrogarse sobre la actitud mostrada por el consistorio oriolano -en realidad, su oligarquía dirigente- ante el surgimiento o acrecentamiento de las jurisdicciones señoriales.

Para empezar, en el caso de las colonizaciones alfonsinas no hay indicios de que la ciudad cuestionara o manifestara la más mínima preocupación acerca de tales egresiones, al menos hasta la oleada desatada a partir de 1689. Por el contrario, incluso llegó a alentar mediante exenciones fiscales de carácter temporal a las primeras hornadas de pobladores que los señores necesitaban establecer en sus dominios para alcanzar dicho rango jurisdiccional. Así, en 1491 el consell oriolano dio cumplida satisfacción a Jaime Santángel cuando solicitó exención de sisas y contribución de muro durante 20 años para facilitar el asentamiento de los nuevos pobladores -mudéjares y cristianos- que pretendia atraer a Redován.(88)

Durante el siglo XVI no se produjo colonización alfonsina alguna, pero en la primera tentativa realizada en la siguiente centuria su protagonista no olvidó lejanos precedentes. Así, cuando en 1607 D. Jaime Rossell inició la colonización de Benejúzar también se dirigió a la Ciudad en busca de exenciones fiscales,

"lo qual ha tengut de costum donar en comsemblants ocasions als nous pobladors, fentlos franchs alguns anys de sises, considerat que es de gran utilitat y llustre per a la present Ciutat que llur població y jurisdicció sia aumentada ab la fabrica de nous pobles".(89)

En su respuesta, los jurados de Orihuela otorgaron franquicia, en efecto,

"de totes les sises als pobladors del dit lloch, lo qual es carrer de la dita Ciutat, per temps e terme de deu anys, per a que lo dit don Jaume Rossell ab mes animo pase avant en la fundació del dit poble que te començat y los pobladors tinguen més ocassió de venir a viure y habitar en aquell". 
Pero, además, se cuidaron de señalar que tal concesión era acorde con el espíritu de una antigua ordenanza del consell, que contemplaba la oportunidad de tales exenciones "per a que altres se animen a fundar semblants pobles, illustrant la cosa publica de dita Ciutat".

Siguiendo los pasos de Rossell, la siguiente colonización alfonsina, iniciada en Benferri en 1619, también tuvo a su favor idéntica exención fiscal. En la petición cursada a la Ciudad, D. Jerónimo Rocamora no dejó de hacer mención a la antigua ordenanza del consell, que fechaba exactamente en 28 de octubre de 1543. Y, en la respuesta de los jurados, vuelven a figurar los mismos argumentos justificativos:

"per quant la dita Ciutat está en costum de concedir semblants gracies a les perçones que fundan nous pobles, per lo llustre que reb la cosa publica de la dita Ciutat ab semblants noves poblations, aumentant la jurisdictio dels ordinaris de dita Ciutat y també per que en son temps la dita Ciutat será aumentada en ses rentes ab los delmes y altres pertinencies".(90)

No habría de ser ésta la última vez que Orihuela alentara las colonizaciones alfonsinas, pues todavía en 1684-91 favoreció inicialmente, mediante la concesión de baldios municipales, la inicitiava -finalmente frustrada- de Ginés Juan Portillo en Santa Agueda. Sin embargo, no volvería a conceder ya franquicias fiscales con fines repobladores. $(91)$

A finales del XVII la actitud de la ciudad ya no era tan proclive a la fundación de señoríos alfonsinos, mientras que la antigua retórica justificadora de las exenciones contributivas había ido dando paso a una severa crítica de las consecuencias que solían acarrear tales colonizaciones. Una larga experiencia acerca de los problemas que planteaba al ámbito urbano la proliferación de señoríos podría explicar, en principio, este cambio de actitud, que ya tuvo ocasión de insinuarse a comienzos de la década de 1690 y se expresó con toda su crudeza en 1700.(92)

Pero las reiteradas manifestaciones de antaño acerca de los supuestos beneficios que obtendría la ciudad de las iniciativas colonizadoras no dejan de resultar sospechosas, habida cuenta de que tampoco entonces la experiencia anterior avalaba una coexistencia exenta de conflictos. Más aun, cuando precisamente en 1491, 1607 y 1619 -años de concesión de las franquicias fiscales a los señores de Redován, Benejúzar y Benferri, respectivamente- la ciudad andaba en pleitos con los restantes señoríos sobre la percepción de sisas.(93) Ciertamente, las concesiones de exenciones a los colonizadores -y la propias peticiones que las precedían- en tales coyunturas conflictivas podían representar una baza más en contra de las pretensiones señoriales, pues implicaban el reconocimiento de una relación de subordinación fiscal con respecto a la ciudad. Pero la dudosa efectividad de esa hipotética arma arrojadiza difícilmente podía compensar su coste inmediato.

Por su parte, el argumento poblacionista sí contaba a su favor con una crónica escasez demográfica que en todo momento preocupó al poder urbano.(94) De ahí, por ejemplo, las reiteradas peticiones elevadas a la Corona en una coyuntura de auge demográfico -entre 1573 y 1605 - para que se permitiera a la ciudad atraer a 500 fami- 
lias de moriscos granadinos.(95) Pero una política poblacionista auspiciada por la ciudad no tenía por qué abarcar necesariamente a los grandes dominios que ciertos particulares poseían en el ámbito rural, si ello conllevaba -era el caso de las colonizaciones alfonsinas- una egresión jurisdiccional. De hecho, la tan socorrida ordenanza del consell de 28 de octubre de 1543, legitimadora de las exenciones fiscales a los nuevos señores, no había sido concebida con ese expreso propósito, aunque posteriormente se hiciera una lectura interesada de la misma, pues textualmente sólo establecía

"que totes les perçones que edifiquaran cases en la present Ciutat, ço es, perçones forasteras que vinguen a poblar a la present Ciutat los fan francs de taches reals y de les taches de la present Ciutat y del real de la sal y del real del mur y de totes les altres taches que los vehins de la present Ciutat acostumen pagar, per temps e terme de deu anys comptadors de huy avant".(96)

En consecuencia, o se apostaba por una política poblacionista a cualquier precio, o había que dar por supuesto -eterna aspiración de la ciudad- que los señoríos alfonsinos no eran más que meras calles de Orihuela; y sus moradores, nuevos vecinos que acudían de fuera. Pero la realidad no era necesariamente ésa y la ciudad no carecía de alguna experiencia al respecto. Es más, trás la expulsión de los moriscos en 1609 trató de impedir a sus moradores el éxodo hacia los señoríos que habían quedado despoblados: Cox, La Granja, Albatera y, parcialmente, Redován.(97)

El apoyo de la ciudad a determinadas iniciativas señoriales quizá se entienda mejor si se toma en consideración la personalidad de sus protagonistas y las relaciones que mantenían con el poder urbano en el momento preciso. Así, D. Jaime Santángel no sólo era Bayle General de Orihuela en 1491 e influyente hombre de negocios, sino que, además, dias antes de obtener la gracia solicitada había intervenido decisivamente en una reestructuración del sistema político municipal que acabó consolidando las posiciones de la oligarquía dirigente.(98) Perteneciente a uno de los linajes más antiguos de Orihuela, D. Jaime Rossell, que había obtenido la titulación nobiliaria en 1606 , se hallaba inmerso en un interesante proceso de acumulación patrimonial y mantenía relaciones económicas con la hacienda urbana, al tiempo que preparaba su carrera en la administración real a través de la Gobernación y, posteriormente, en la Baylía General de Orihuela-Alicante.(99) D. Jerónimo Rocamora añadía a su condición de mayor hacendado de Orihuela la de principal prestamista de las arcas municipales, amén de sus estrechas vinculaciones como abastecedor urbano de carne y trigo.(100) Finalmente, Gines Juan Portillo, caballero y familiar del Santo Oficio, venía ejerciendo con carácter vitalicio el cargo de secretario de la ciudad, que había heredado de su padre, y era cuñado del todopoderoso asesor de la misma, el Dr. Domingo Ruiz.(101) Se trataba, pues, de influyentes personalidades en la vida local cuyas vinculaciones clientelares con la oligarquía municipal la habían hecho acreedoras a favores especiales.

En cualquier caso, si la condición de señor alfonsino difícilmente podía ser cuestionable -aunque sí lo fueran algunas de sus derivaciones- mientras sus titulares cumplieran los requisitos contemplados en el fuero de 1329, los pretendientes al 
ejercicio de la jurisdicción civil debieron tener mayores dificultades para hacerla valer en época moderna. La creciente devaluación de esta categoría señorial, ignorada incluso por tratadistas como Belluga y Matheu,(102) no evitó, sin embargo, esporádicas manifestaciones acerca de su vigencia legal; por mucho que, en la práctica, resultase difícil hacerla efectiva. En 1578, por ejemplo, se suscitó controversia acerca de la situación jurisdiccional correspondiente a los señoríos de Daya Vieja y Rojales, ambos en término de Orihuela. Pero, curiosamente, ni las partes en litigio eran los señores respectivos y la ciudad, ni el tema central del pleito tenía mucho que ver con la jurisdicción señorial.

Así, habiéndose entablado pleito sobre la altura de una presa hidrahúlica entre los regantes de la acequia de Callosa -que transcurría por siete municipios- y el propietario de un molino -que pretendía interesar en su causa al mayor número posible de lugares situados río abajo-, argumentaban los primeros que

"lo lloch de Rojals...es una aldea constituhida en lo terme y horta de la present Ciutat, davall la jurisdictiò ordinaria de aquella, y lo propri señor del dit lloch de Rojals es nostre Rey y Senyor Don Phelip y no gens lo dit Pere Masquefa, que solament té en lo dit lloch y aldea una particular heretat, com altres molts particulars que habiten en dit Iloch tenen; e per semblant lo dit Mosen Jaume Roca de Togores nos pot dir señor del lloch de la Daya Vella, per que com V.Sa. té molt be entés, no es lloch ni població alguna, ni té jurisdictio alta ni baixa ni minima, sino tan solament es una heretat particular en la qual llauran serts llauradors y tenen sols una casa per a acollirse y albergarse ells y los fruits...Rojals y la Daya Vella nos puguen dir universitats conforme als furs del present Regne, com aquells no sols no tinguen quatorze casses, ni encara set".

La parte contraria, quizá menos realista, replicaba, en cambio, en términos jurídicos aparentemente más sólidos:

"los furs que senyalen lo dit numero de cases en los llochs es en cas different del nostre, y es que per a que los senyors de aquells tinguen la jurisdictio criminal en sos llochs, que lo fur del rey Don Alfonso els concedeix, requereix dit numero; empero per a ser universitat y per a la jurisdictio civil, encara que no sien lo dit numero de casses, per fur antich fan universitat y lo senyor té la jurisdictio civil, e de justicia e rahó natural scrita meins numero que set fan y representen universitat".(103)

A diferencia de la alfonsina, en efecto, el ejercicio de la jurisdicción civil no exigía un mínimo de casas, pero podían plantearse problemas si quedaba el señorío totalmente despoblado. De ellos precisamente se hicieron eco las cortes de 1547, al pretender los brazos real y eclesiástico -sin mucho éxito- que, en tales circunstancias, se impidiera a esos señores de despoblados el conocimiento "de qualsevulla clams que seran fets en lo dit loch active \& passive", por haberse consolidado la jurisdicción civil "ab la jurisdictio ordinaria de la vila real en terme de la qual lo dit loch es situat".(104)

Pero, para poder reclamar el ejercicio de la jurisdicción civil, la cuestión de fondo debía ser, independientemente de la existencia o no de pobladores, el origen del pre- 
tendido dominio señorial. Y, sin embargo, en el término oriolano no es frecuente encontrar planteamientos en este sentido, excepto cuando el tema de debate era el derecho sobre los pastos y amprius -del que se tratará más adelante. De los dos ejemplos mencionados, la condición señorial de Daya Vieja podría haberse sustentado aunque no hay constancia de ello- en una probable división territorial de la antigua baronía de La Daya que, sin embargo, no habría alcanzado a la jurisdicción suprema, permaneciendo ésta en el titular de Daya Nueva.(105) En tal caso, no carecía de fundamento el origen feudal de Daya Vieja, pese a la evidente ausencia de pobladores confirmada por inventarios y otros documentos de los siglos XVI y XVII.(106)

La pretendida categoría señorial de Rojales era, sin embargo, más difícil de justificar. Ciertamente, se trataba de un lugar poblado cuyo vecindario pudo alcanzar en algún momento el mítico número de quince;(107) pero no todas las casas que habitaban ni las tierras que cultivaban estaban sometidas a dominio señorial. En realidad, este último abarcaba a principios del XVII una extensa heredad, una torre de defensa, una casa principal, con su hermita, y otras seis más pequeñas en el entorno, dos molinos -uno harinero, otro arrocero-, unas heras y unas balsas de cocer lino y cáñamo. Las tierras del señor eran cultivadas, parte en arrendamiento, parte en aparcería -con partición al cuarto-, parte en enfiteusis; y también algunas casas tenían su dominio útil censido. Los pocos enfiteutas del lugar, además, -pero sólo ellos- quedaban obligados a utilizar los molinos, heras y balsas señoriales, pagando los derechos correspondientes, y a residir en Rojales.(108) En ausencia de cualquier otro título de dominio, todo ello podía resultar insuficiente para otorgar a sus señores, los Masquefa, más jurisdicción que la derivada del dominio directo -expresamente reservada en los capítulos de establecimiento-, aunque la obligación de uso de determinadas regalías quizá remita a un tipo de relaciones señoriales algo más complejas. Con todo, hacia 1620 el cronista coetáneo Mosen Bellot, tras indicar que Rojales "ha sido siempre un número de casas de heredades juntas" afirmaba que "en nuestros dias Frances Masquefa hizo algunas casas más y tiene su justicia, aunque teniente del de Guardamar",(109) que, a su vez, era Iugarteniente del de Orihuela.(110) Las casas recientemente edificadas lo habian sido, además, en tierras baldías expresamente concedidas por la ciudad al dicho Masquefa en 1611,(111) debiendo estar comprendidas en esas seis ya mencionadas. Años atrás, finalmente, también hay constancia de un lugarteniente de justicia en Rojales, dependiente de Guardamar, sin que en esta ocasión el cargo fuera ejercido por un Masquefa.(112)

En una situación jurisdiccional no menos precaria que la anterior debían encontrarse quienes, a lo largo del XVI, se intitulaban señores de Benejúzar. Desde antes de su colonización alfonsina -iniciada en 1607-, también aquí hubo pobladores -cuyo número fluctuó en torno a la decena a lo largo del XVI-,(113) ninguno de los cuales alcanzó siquiera la condición de enfiteuta. Según inventario de bienes del señor, Nicolau Martí, realizado en 1579, se trataba de aparceros que cultivaban la tierra con partición al quinto y criaban la seda a medias y al tercio.(114) Pese a su titulación señorial, Benejúzar tampoco parece que planteara problemas jurisdiccionales a la ciudad; que la consideraba, a todos los efectos, un caserío de su jurisdicción. En 1582, al 
ser interrogados sobre si se trataba de una "heretat de llauradors, o lloch" y, en este último caso, si disponía de justicia, ninguno de los testigos pudo responder afirmativamente a esta segunda cuestión. En relación a la primera, casi todos declaraban ser lugar de unas 8 ó 10 casas, con iglesia construida. Y los mejor informados precisaban:

"es un Hoch de quatre o cinch cavallers, que son Françés Masquefa, Dona Leonor Pons, Mosen Vicent Martí, Nicolau Martí e Pere Martí, los quals tenen ses heretats partides y cascu té donades ses terres a sos llauradors al quint, los quals llauradors habiten de ordinari en lo dit lloch de Benejusser, hon tenen ses cases";

o bién:

"vulgarment a oit nomenar lloch a Benejusser...y encara que huy es de diverses perçones, empero el testimoni lo ha conegut de un señor, que fonch to Magnifich Luis Martí, cavaller".(115)

El cronista Bellot, por su parte, al referirse a Benejúzar, afirmaba que "no era antiguamente lugar formado, sino casas de heredades y de hombres trabajadores juntas, anque la mayor parte era de los caballeros del apellido Martí, y así les intitulaban señores de Benejúzar".(116) Pero, pese a tales titulaciones, en ningún momento hay constancia de que tales señores reclamaran algún tipo de jurisdicción.

En realidad, la titulación de señor, sin más aditivos, era utilizada con cierta frecuencia por los poseedores de grandes heredades, sin que ello les llevara necesariamente a pretender jurisdicción alguna. Era el caso, por ejemplo, de Ginés Jordi de Gascó, quien en su testamento de 1615 se intitulaba señor de Formentera.(117) También los titulares de la heredad de Rafal se denominaban señores antes de su colonización alfonsina, aunque no carecian totalmente de fundamento, pues una parte de la misma había sido establecida a censo.(118) En todos estos casos -Rojales, Benejúzar, Formentera, Rafal- da la sensación de que ni siquiera sus señores conocían el orígen de sus dominios, excesivamente extensos -algunos superaban las 100 hectáreas de huerta- como para haberse formado exclusivamente a través del mercado y de las estrategias matrimoniales.(119) Quizá algunos dieran por sentado que el núcleo originario se remontaba a antiguas infeudaciones o privilegios de concesión, tal como hacían -con relativo éxito- los señores de Benferri y Jacarilla, y trataran de actuar en consecuencia. Pero, de cualquier forma, esa hipotética oscuridad de origen difícilmente haría prosperar cualquier pretensión sobre la jurisdicción civil.

A diferencia de las jurisdicciones menores, el ejercicio de la baronal sí fue objeto de preocupación frecuente para la ciudad, destacando especialmente los conflictos planteados con el señor de Albatera. La alta jurisdicción criminal sobre este antiguo señorío había sido otorgada a D. Ramón de Rocafull por Juan II mediante privilegio expedido el 19 de enero de 1463 en recompensa a los servicios prestados durante la contienda catalana.(120) Esta circunstancia no era desconocida a dos bien informados cronistas de principios del XVII, como eran Gaspar Escolano(121) y Mosén Pedro Bellot,(122) lo que hace difícil creer que pudiera ser ignorada por los propios señores, sobre todo a partir de 1611, en que fue publicada la obra del primero. $\mathrm{Y}$, sin embargo, 
al menos durante el siglo XVII los Rocafull no parece que llegaran a exhibir el privilegio acreditativo, pues todas sus pretensiones al respecto se fundamentaron en la posesión inmemorial. Por su parte, la ciudad de Orihuela no dejó de aprovechar este curioso defecto de título para apoyar sus reiteradas reivindicaciones sobre la alta jurisdicción criminal, aunque nunca llegó a obtener sentencia favorable.

Así, en 1601-1602 Orihuela no pudo impedir, pese a todas sus instancias ante Ios tribunales, que el señor de Albatera apresara, sentenciara y ejecutara en la horca a un vasallo morisco acusado de homicidio, cuando aun estaba pendiente de resolución el pleito entablado por la jurisdicción suprema. En mayo de 1602 la ciudad llegó a dar instrucciones a sus procuradores para que abandonaran el pleito en caso de que el señor mostrara el privilegio acreditativo; pero ni tan siquiera una sentencia de la Audiencia de Valencia publicada cuatro meses más tarde contra las pretensiones de la ciudad bastó para que ésta cediera en su empeño.(123) Así quedó de manifiesto en las Cortes de 1604, al pretender el señor de Albatera que el monarca ordenara "imposar silenci perpetuo als dits Procurador Patrimonial y Syndich de Oriola en dit plet", pues habian recurrido la sentencia. Pero tampoco en esta ocasión esgrimió en su favor privilegio alguno, sino únicamente que

"de temps inmemorial a esta part ha estat y está continua e inconcusament en possessió de la dita suprema jurisdictio, mer y mixt imperi, y aixi, haventse fermat de dret sobre la dita possessió, seu quasi, ab sentencia donada en la Real Audiencia en lo any 1602 , fonch declarat en favor de aquell'.(124)

Sucesos criminales similares a los de 1601-2 se repitieron en Albatera en 1613, reavivando nuevamente el pleito. Según informaba la ciudad, en esta ocasión el señor había obtenido una provisión de la Audiencia

"per a que lliuren y entreguen uns homens natural de aquesta ciutat (de Oriola), sots pretenció que haurien comes cert homicidi en lo terme de dit lloch (de Albatera), no obstant tenia pres al hu de aquell lo Governador per dit delicte, pretenent que ad aquell y no al dit Governador se es guardaría de coneixer đel dit delicte".(125)

Puesto que, según recelaba la ciudad, el Gobernador no tenía intención de oponerse, aquélla entabló pleito en la Audiencia en defensa de la jurisdicción de su justicia criminal, pretendiendo que, en ausencia de título, el señor de Albatera "sols pot usar de la jurisdictio alfonsina y no de la suprema". Pero tampoco esta vez consiguió su propósito.(126)

Ante tan irreductible posición, los señores de Albatera tuvieron que procurarse periódicamente instrumentos legales que le permitieran respaldar su posesión inmemorial sobre la alta jurisdicción criminal. Así, en 1644, el señor exponía ante el Consejo de Aragón que su padre había conseguido, en 1619, se despachasen provisiones reales y "lletres de manutenencia" para que no se le impidiese el uso y ejercicio de la jurisdicción suprema; y acababa solicitando copia de las mismas, autentificada por la secretaría de dicho Consejo, toda vez que las originales no aparecían en los registros de Orihuela.(127) Por si todo ello no bastaba y ante el temor de que su 
rango jurisdiccional pudiera ser nuevamente cuestionado, en 1687 el señor de Albatera volvía a obtener de la Audiencia valenciana cartas de manutención, tras haber presentado información de testimonios y haberle sido admitida la correspondiente firma de derecho, sobre la

"inmmemorial possessió de la jurisdicció civil y criminal, alta y baixa, mer y mixt imperi, us y exercici de aquella, en dita vila de Albatera y son terme, de castigar los delinquents en aquella y son districte fins a pena de mort natural, imposar totes les penes, aixi corporals com pecuniaries, segons la calitat dels delictes comesos, remetre en sos cas y llochs aquelles, y en senyal de dita jurisdictio suprema, us y exercici de aquella, tenir forca erigida en lo cami real que va a dita vila".(128)

Naturalmente, al notificarse a la ciudad, el síndico de ésta conjuntamente con el procurador patrimonial pidieron revocación de tales provisiones, ya que habían sido obtenidas sin citación de la parte que ellos representaban. Se iniciaba así un nuevo proceso -aun continuaba en 1690-(129) que, a todas luces, difícilmente podía ganar Orihuela, dados los antecedentes que obraban en su contra. En consecuencia, la reiterada negativa de la ciudad a reconocer el rango jurisdiccional de los señores de Albatera en ningún momento parece que impidiera a sus titulares el ejercicio efectivo de sus atribuciones en materia criminal.

En el caso de La Daya o Daya Nueva esta cuestión tampoco dejó de provocar algún conflicto con la ciudad, aunque las escasas noticias al respecto para la edad moderna pecan de imprecisas. Así, en 1567, con ocasión de uno de los múltiples pleitos que Orihuela sostuvo en materia de amprius, llegó a cusetionarse no sólo el rango jurisdiccional sino incluso la condición de lugar, basándose en una pretendida inexistencia de población estable, consecuencia a su vez del régimen adoptado para la explotación de la tierra:

"la Daya es una heretat com totes les altres de la orta de Oriola, que los que habiten en la dita heretat de la Daya son llauradors quinters y no vasalls, ço es, que llauran alli al quint, y lo dia que no volen llaurar sen van del lloch sens demanar compte ni besconte al Senyor, com en les altres llochs los vasalls a sos amos, y si aço es pot dir lloch tenint los homes desta manera, totes les heretats de la horta de Oriola podrien allegar lo mateix".(130)

Movida de un excesivo celo, es probable que la ciudad tomara, interesadamente, la parte por el todo -a no ser que estuviera confundiendo Daya Nueva con Daya Vieja, pues al menos para principios del XVII hay constancia de la existencia de establecimientos enfiteúticos y de oficiales municipales -justicia, jurados- y señoriales -bayle, procurador- en el lugar, cuyo vecindario venía oscilando entre 25 y 50 casas desde un siglo atrás.(131) Y no hay indicios suficientes para suponer que la situación anterior fuera sustancialmente distinta.(132) En cualquier caso, la linea argumental esgrimida por Orihuela, aunque podía resultar efectiva contra algunos potenciales pretendientes a la jurisdicción civil, difícilmente conseguiría surtir efecto en el caso de la Daya, cuyo rango baronal hacía remontar el señor hasta 1330. Así lo hizo en las cortes de 1604 , al pretender confirmación por el Monarca de ciertos privilegios de concesión 
expresamente aducidos.(133) Uno de los privilegios en cuestión otorgaba, en efecto, la jurisdicción suprema sobre la Daya a un tal Gonzalo Garcia, de cuyo descendiente pasó a los Masquefa -según Bellot, por compra realizada el 6 de abril de 1353-; y, ya en 1629, por falta de sucesión directa, al Conde de Albatera, quien se apresuró a recibir juramento de fidelidad y vasallaje de los vecinos de La Daya como nuevo titular de la "jurisdictione suprema, tam civili quam criminali, mero et mixto imperio" y a realizar los demás actos acostumbrados en las tomas de posesión.(134)

Con todo, la posesión señorial de este nivel jurisdiccional aun volvería a ser cuestionada por Orihuela. En 1682, antes de decidirse a entablar pleito por un asunto referente a la jurisdicción sobre las aguas, la ciudad prefirió cerciorarse sobre sus posibilidades de éxito, solicitando de su antiguo abogado y asesor, el Dr. Vicente Xodar, que también lo había sido del Conde de Albatera, informe confidencial acerca de si dicho señor tenía privilegio de barón sobre La Daya.(135) Ignoro la respuesta del anciano jurista, pero cuando cinco años más tarde el Conde obtuvo de la Real Audiencia provisiones a favor sobre la jurisdicción suprema del lugar, la ciudad no dudó en iniciar el proceso correspondiente. (136) Y en 1690, como la causa continuaba pendiente, se decidió contradecir incluso una provisión de la Audiencia acerca de la forma de despachar las ejecuciones dictadas por el tribunal de la Baylía contra la Daya, pretendiendo que dicho lugar, al igual que Albatera, "no son varonies, ni tenen terme, si merament carrers de la present Ciutat".(137) Pero, por mucho que se insistiera, estas reivindicaciones urbanas dificilmente podían impedir al señor el ejercicio efectivo de la jurisdicción suprema.

Por otro lado, no conviene olvidar que, durante el segundo cuarto del siglo XVII, casi todos los señores alfonsinos del término oriolano consiguieron la jurisdicción suprema gubernatorio nomine. Dada su reciente adquisición, la ciudad no podía discutir en estos casos el rango alcanzado por sus titulares. Pero nada le impedía expresar su malestar por tales enajenaciones jurisdiccionales; y así lo hizo de forma particular en 1640 -al margen de su previsible protagonismo en las ya aludidas peticiones expresadas por el brazo real en Cortes de 1626 y 1645-, al solicitarinútilmente- de la Corona que

\begin{abstract}
"por quanto los señores Reyes predecessores de V. Magd. hizieron merced a dicha Ciudad de no separar ni apartar de su jurisdicción los lugares de su contribución...le haga merced que todos los lugares que hoy estan dentro de los términos generales de dicha ciudad, los quales son desde los mojones de la villa de Elche hasta los mojones del término de la Ciudad de Murcia, no se les conceda por V. Magd. jurisdicción suprema ni de gubernatorio nomine, y que si algún señor edificare dentro de dichos términos algún lugar, no pueda tener en él otra jurisdicción más de la Alfonsina que tiene por fuero del Reyno de Valencia".(138)
\end{abstract}

Puesto que no estaba en su mano impedir la proliferación de jurisdicciones alfonsinas -dependientes de iniciativas colonizadoras privadas- ni supremas -dependientes de la voluntad regia- y la resistencia al reconocimiento de estas últimas apenas se traducían en algo más que meras actitudes testimoniales, Orihuela trató de evitar, al menos, la pérdida de ciertas atribuciones y preeminencias que podían deri- 
varse de las segregaciones señoriales. En realidad, más que el rango jurisdiccional, fueron estos derechos y competencias concretas los que enfrentaron con mayor frecuencia a la ciudad con los señores, aunque se plantearan a menudo de manera conjunta y acabaran cuestionando la propia titulación jurisdiccional.

Una de las atribuciones en litigio más directamente relacionada con el tema jurisdiccional -como ya se ha visto en otros ejemplos referentes al Reino de Valencia- era la forma en que habían de dirigirse los oficiales urbanos a los señoríos. El tema comportaba no sólo una cuestión de preeminencia, sino también una vertiente práctica inmediata, como era la capacidad para hacer operativas las ejecuciones judiciales. A este respecto, la ciudad del Segura obtuvo en 1610 una provisión de la Audiencia que prohibía a los señores "dels llochs circunvehins a la ciutat de Oriola y contribució de aquella, com son Redová, La Granja, Benejússer, La Daya e altres" impedir a los justicias y otros oficiales urbanos proceder "via directa y sens lletres subsidiaries" en las ejecuciones contra los vasallos señoriales.(139) La real provisión, pues, no distinguía entre baronías y señoríos alfonsinos. Al ser notificada a los interesados, los justicias de La Daya y Albatera -que se dio por aludido, aunque no se hiciera mención expresarespondieron que protestaban y no consentían; el señor de Benejúzar pidió traslado y se reservó el derecho de ejercer las acciones legales que considerase oportunas; y el titular de Cox, aunque precisaba que no se hacía alusión a su señorío, pidió revisión.(140) Siete años más tarde el proceso consiguiente, instado por varios señores, aun estaba pendiente de resolución en la Audiencia valenciana;(141) que, al parecer, no llegó a modificar su criterio al respecto. Así, cuando en 1629 los jurados oriolanos pregonaron un bando sobre la forma en que habían de redactarse los despachos dirigidos a los señoríos por los escribanos de los tribunales urbanos, se acogieron expresamente a lo dispuesto por la real provisión de 1610.(142) El hecho de que algunos señores -los de La Granja, Benejúzar y Cox-interpusieran de inmediato escrituras de apelación prueba, no obstante, que el asunto en modo alguno había quedado zanjado.(143) Aunque no es posible asegurarlo, quizá acabara imponiéndose el criterio de exceptuar únicamente a los titulares de jurisdicción suprema del grado de subordinación que implicaba aceptar en sus dominios ejecuciones "de directo", en vez de despachos "subsidiarios". Pero la mera existencia de la real provisión de 1610 muestra amén de otros ejemplos al respecto ya mencionados para otras comarcas valencianasque el alcance real de las jurisdicciones señoriales no siempre coincidía con el que podría deducirse de su titulación nominal.

A título comparativo y como elemento de contraste conviene añadir que en el caso de las universidades realengas, aun sin gozar de la jurisdicción suprema, las ejecuciones contra sus vecinos no podían realizarse de directo, sino mediante "lletres subsidiaries".(144)

\section{Conflictos sobre la jurisdicción de aguas}

Limitación no menos importante a la jurisdicción señorial fue la relativa a las aguas de riego. Ciertamente, algunos señores alfonsinos y baronales disponían de oficiales encargados de resolver las denuncias y conflictos suscitados entre sus pro- 
pios vasallos por cuestiones de riego y de velar por el correcto mantenimiento y administración de la red hidrahúlica en su dominios. Pero, puesto que todos los señoríos tomaban el agua de acequias mayores que también irrigaban territorios ajenos, estos cequieros o sobrecequieros señoriales carecían de jurisdicción cuando alguna de las partes implicadas en un litigio -actor o reo- era vecino de otro municipio o el daño causante de la denuncia se había infligido fuera del señorío, pues en tales casos su ejercicio recaía sobre el sobrecequiero de Orihuela. Durante las últimas décadas del Quinientos, en efecto, multitud de denuncias solventadas ante el juez de aguas urbano fueron presentadas por cequieros, síndicos, jurados y vasallos particulares de Redován, Cox, La Granja y Albatera, sin que haya constancia de oposición señorial alguna a esta antigua práctica.(145)

En 1617, sin embargo, esta preeminencia jurisdiccional del sobrecequiero de Orihuela fue cuestionada por los señores alfonsinos de Cox y La Granja, al pretender que tales denuncias debían presentarse "ante el Sobrecequiero del lugar donde se haze el daño".(146) Como parte interesada en el proceso subsiguiente figuraba el barón de Albatera, pero no en apoyo de las pretensiones señoriales, sino en favor de la jurisdicción de Orihuela. Esta aparente paradoja -un señor baronal defendiendo la jurisdicción de la ciudad contra las reivindicaciones de otros señores alfonsinosresulta, no obstante, comprensible, pues los tres señoríos mencionados regaban de la misma acequia, siendo el de Albatera el último en hacerlo al estar situado en su tramo final. Consiguientemente, puesto que la mayor parte de las denuncias se debían a hurtos de agua y otras acciones punibles cometidos por los regantes de los tramos superiores -Cox y La Granja-, el sobrecequiero de Orihuela ofrecía más garantía de imparcialidad a los vasallos de Albatera que el de aquellos señoríos. Esta discrepancia entre señores sobre el alcance de su jurisdicción en materia de aguas expresaba, pues, la natural divergencia de intereses entre regantes jussans y subirans y no constituía novedad alguna.(147) En 1548, por ejemplo, el titular de Albatera había conseguido, en contra del criterio defendido por los de Cox y La Granja, que el sobrecequiero oriolano incrementara las multas por infracciones de riegos, argumentando la escasa capacidad disuasoria de las vigentes por entonces.(148)

La defensa de la jurisdicción del sobrecequiero de Orihuela resultaba esencial, por tanto, para salvaguardar los intereses de los regantes de Albatera -y, por ende, la renta señorial. Pero también podía comprometer su categoría baronal, pues la ciudad -que mantenía pleito sobre la misma- argumentaba en términos bastante explícitos:

"no havent conegut may de tals (clams) lo sobrecequier de Coix dels de Albatera ni lo sobresequier de Albatera dels de Coix, si tan solament lo sobrecequier de Oriola, per dos rahons, la primera per que sols esta Ciutat te priviletgi per a tenir sobresequier de aquella y de tot son terme y no les dits pobles, que son carrers de esta Ciutat, y la altra per que los senyors de dits llochs, per tenir sols la jurisdictio alfonsina, sols tenen jurisdictio inter suos y no la tenen per a coneixer dels vasalls de altres senyors, y també per que tots los habitants en dits pobles estan subjectes al sobresequier desta Ciutat en materia de aygues per ser tots sos vehins y pendre aygua per a regar dins lo terme desta Ciutat, per ser sos carrers".(149) 
Ciertamente, la relación entre categoría señorial y jurisdicción sobre aguas no era tan directa como pretendía la ciudad, pero cuando en 1646 se tuvo noticia de que los titulares de La Granja y Cox pretendían alcanzar la jurisdicción suprema gubernatorio nomine, fue el Conde de Albatera quien se apresuró a dirigir un memorial al Consejo de Aragón solicitando que en dichas concesiones "se declare no ser la intención hacer novedad en perjuicio del suplicante...porque todo lo tocante a las dichas aguas se ha de juzgar por el Sobrecequiero de Orihuela".(150)

El tema, en efecto, aun estaba candente, pues aunque la Audiencia de Valencia habia pronunciado sentencia favorable a la ciudad y al de Albatera en 1618, el señor de Cox -que ya habia obtenido la gubernatorio nomime en 1630- volvió a plantear nuevamente sus reivindicaciones sobre la jurisdicción de aguas en 1641.(151) En esta ocasión aducía el de Cox una sentencia pronunciada por la Audiencia en 1628 en favor del sobrecequiero de la universidad realenga de Callosa contra los regantes de la aldea de Catral, dependiente de Orihuela. Los problemas entre Callosa y Catral eran similares a los que enfrentaban a los señores mencionados, pues ambas regaban de la misma acequia mayor y eran los de Callosa, al hacerlo en el tramo superior, quienes solían perjudicar a los de Catral. La sentencia al respecto establecía en este caso que las denuncias debían realizarse ante el sobrecequiero del lugar al que perteneciera el reo; y, lógicamente, el señor de Cox pretendía que esta doctrina se aplicara también en su caso.(152) Pero todo parece indicar que sus reclamaciones no llegaron a prosperar, permaneciendo en pleno vigor la sentencia de 1618.(153) Se asiste así a una situación un tanto paradójica: un señorío de jurisdicción suprema -el de Cox, pero también el de Albatera- con atribuciones más limitadas en asuntos de aguas que una universidad realenga -Callosa- que, por definición, carecía de aquélla.

En los restantes señoríos de la huerta no hay constancia de que sus respectivos titulares presentaran reclamaciones similares a las de Cox, debiéndose entender que su jurisdicción en materia de aguas quedaba reducida a aquellas cuestiones que no implicaran más que a los propios vasallos. Además, a excepción de Benijófar, que regaba de una acequia propia, todos ellos lo hacían de acequias mayores que nacían y discurrían por territorio realengo, estaban integrados en comunidades de regantes de mayor alcance territorial y sometidos a la jurisdicción de otros sobrecequieros. Así, los señoríos de Rafal y Benejúzar formaban parte de la comunidad de la Acequia Vieja de Almoradí; los de Bigasto y Jacarilla, de la Acequia de Alquibla; y el de Molins, de la Acequía de Molina; todos ellos bajo la jurisdicción del sobrecequiero de Orihuela. Por su parte, los de la Daya, La Puebla y Formentera estaban integrados en la comunidad del azud de Alfeytamí, cuya jurisdicción recaía sobre el sobrecequiero de la universidad realenga de Almoradi.

Obviamente, esta dependencia de los señoríos, necesaria para el buen funcionamiento del sistema hidrahúlico, no eliminaba todas sus inmunidades jurisdiccionales. Así, por ejemplo, cuando en 1618 fue necesario despachar ejecuciones por impago de derramas contra el señor de La Daya, el sobrecequiero de Almoradi tuvo que dirigirse al de la baronía, por defecto de jurisdicción para actuar de directo, para que éste sacara prendas de la casa señorial -con resultado previsible: no se hallaron 
mas bienes que los privilegiados.(154) Y en 1695 los barones de La Daya y La Puebla -el Conde de Albatera y el Marqués de Rafal, respectivamente- impidieron al sobrecequiero de Almoradi realizar la medición de las tierras regantes en ambos dominios;(155) para, posteriormente, negarse a pagar las contribuciones que le fueron asignadas y a permitir las ejecuciones consiguientes.(156)

Pero, al tratar de ampararse en la jurisdicción para burlar la acción de la justicia en materia de aguas, los señores acabaron propiciando la intervención regia en apoyo de la autoridad de los sobrecequieros de los municipios realengos y, en particular, el de la ciudad de Orihuela. Ya en 1624, el envío de un comisario plenipotenciario -visitador de aguas- y la consiguiente promulgación de unos estatutos de riego para toda la huerta -ordenanzas de Mingot- permite una interpretación en este sentido; aunque tal reforzamiento no fuera el único, ni probablemente el más importante, objetivo de la operación.(157) Paso más decisivo se avanzó, en cambio, hacia 1635, merced a la vinculación orgánica de la asesoría del sobrecequiero de Orihuela -y, por extensión, las asesorías de los demás sobrecequieros del realengo- a la Asesoría de la Gobernación; y en 1699, mediante la confirmación y nueva concesión al asesor de la Gobernación(158) -y no ya al sobrecequiero- de los poderes necesarios para actuar e introducirse en aquellos señoríos que pretendieran inmunidad.(159) Con ello, la jurisdicción de aguas ganaba en eficacia, pero empezaba a sustraerse de las instancias municipales.

\section{Litigios sobre contribuciones y otras obligaciones vecinales}

Cuando en 1579 y 1583 las aldeas realengas de Callosa y Almoradí adquirieron título de universidad, los capítulos 17 y 18 de dichos privilegios establecieron como era habitual en este tipo de segregaciones- la total independencia fiscal con respecto a la ciudad matriz: Orihuela.(160) La exención de contribuir en los impuestos urbanos también le había sido reconocida a Guardamar, en este caso desde época medieval, merced a su peculiar vinculación jurisdiccional con la ciudad.(161) Los municipios señoriales, en cambio, jamás pudieron acogerse a disposición alguna capaz de liberarles por completo del principio general según el cual quedaban sujetos a las obligaciones fiscales impuestas por la ciudad sobre el vecindario. Esto no significaba, sin embargo, que en todo momento contribuyeran de igual modo y en la misma medida que lo hacían los habitantes de la urbe, dada la diversidad de circunstancias que podían concurrir en cada caso y, sobre todo, la resolución de los conflictos planteados al respecto.

A principios de la edad moderna eran dos, fundamentalmente, los impuestos que la ciudad venía tratando de recaudar en los señoríos, al parecer con éxito desigual, debido a la resistencia ofrecida por algunos señores: el muro y la sisa. El primero de ellos respondía a la necesidad de mantenimiento de las murallas urbanas y su expresión monetaria procedía de la conmutación de servicios vecinales en trabajo por dinero. Desde época medieval, el derecho de Orihuela a exigir la contribución del muro en los señoríos, aunque había provocado alguna que otra fricción, no pare- 
ce que fuera objeto de una oposición frontal. A veces a regañadientes, los señoríos acababan por transigir en sus tentativas de evasión, sobre todo cuando la ciudad les recordaba las exenciones de determinados derechos reales y de la Generalidad del Reino de que gozaban, como vecinos de su general contribución, y les amenazaba con su exclusión. En 1411, por ejemplo, anota Bellot que "siendo requeridos los vecinos de La Daya a obrar el muro por su tanda, vino por ellos Jaime Masquefa (su señor) y pagó por catorce casados que había".(162) Según el mismo cronista, en 1407 la ciudad alegó que los moros de Albatera "han acostumbrado venir a la obra de los muros" y en 1410 era el propio señor quien garantizó que continuarían contribuyendo por este concepto.(163) A lo largo del siglo XV esta obligación vecinal, aunque posiblemente mantuvo su forma originaria de servicio en trabajo para los residentes en el núcleo urbano, fue conmutada por dinero en la huerta y los señoríos, siendo la cuota habitual de un real por casa a finales de la centuria.(164)

Mediante su conversión monetaria se trataba de impedir la evasión de esta carga vecinal a los residentes en los extramuros y facilitar su contribución. Pero, quizá por negligencia de la propia ciudad, en algún caso pudo llegarse a una especie de encabezamiento que acabó desvirtuando la pretendida igualdad contributiva. Así, cuando en 1491 trató de recaudarse el real del muro, el titular de Albatera alegó que su señorío sólo contribuiría con la cantidad acostumbrada, consistente en 20 reales ó 30 sueldos valencianos.(165) Naturalmente, los jurados oriolanos negaban la existencia de concordia alguna al respecto "e si alguns oficials se mostras haver ho fet, nosaltres no hu delliberam fer, per no esser cosa justa ne rahonable" y emplazaron al señorío a mostrarla antes de 10 dias.(166) Ignoro si éste pudo hacerlo, pero cuando en 1499 la ciudad requirió del mismo señor que favoreciera al encargado de colectar "el real del mur" en Albatera, obtuvo por respuesta que así lo haría, comprometiéndose a recaudar personalmente entre sus vasallos únicamente los 30 sueldos acostumbrados y entregarlos al colector.(167)

Para una población que por entonces rondaba el centenar de vecinos,(168) las ventajas de esta suerte de encabezamiento a perpetuidad eran obvias. Para la ciudad, por el contrario, significaba no sólo renunciar a su actualización, sino tener que hacer frente a los agravios comparativos que se seguían:

"les pobles se escusen de pagar ab justa raho, puix veen que los moros de aquest loch (Albatera) no son executats, e no seria de raho que nosaltres fesem diferentia en lo pagar de la obra dels murs de huns a altres, car sería cossa de gran reprensió alliviar los moros e carregar los cristians".(169)

Auténtica premonición, pues en algún momento de la segunda mitad de la siguiente centuria Orihuela dejó de recaudar definitivamente este derecho en los señoríos, mientras continuaba haciéndolo en el recinto urbano y en las aldeas realengas.(170) De hecho, cuando a principios del XVII los colonizadores alfonsinos solicitaron exenciones fiscales, no mencionaron dicha imposición -a diferencia del titular de Redován en 1491, que sí lo hizo-, cuya percepción seguía vigente en la ciudad, debiéndose entender que ya no era exigible en los señoríos.(171) 
$\mathrm{Si}$, en virtud de algún mecanismo desconocido, los señores consiguieron evadir sus dominios de la contribución del muro, la recaudación de la sisa -también conocida como sisa mayor- corrió una suerte no muy distinta. Teóricamente destinada al coste de mantenimiento de la administración municipal, la sisa consistía en un gravámen ad valorem aplicado sobre la venta al por menor de varios artículos de consumo.(172) $\mathrm{Al}$ igual que el muro, Orihuela fundamentaba su derecho a exigirla en todos los lugares de su general contribución en su condición de vecinos y, como tales, en los privilegios de que gozaban respecto a otras instancias fiscales.(173) Así, cuando entre 1407 y 1410 los señores de Albatera y La Daya pretendieron eximir a sus vasallos de las sisas urbanas, iniciando pleitos al respecto, Orihuela amenazó con excluirlos, además, del manto protector que significaba la subrogación acordada con la Generalidad en la contribución del tall del drap.(174) La resolución de estos conflictos debió ser favorable a Orihuela, pero ello no se traducía necesariamente en una total equiparación fiscal con respecto a la aplicada en el recinto urbano. Entre otras razones, porque las dificultades para controlar el consumo en los señoríos tendieron a resolverse mediante concordias a la baja.

En 1458, por ejemplo, el titular de La Daya, alegando abusos del concesionario arrendatario- de la sisa, consiguió encabezar su percepción en el señorío por diez años en una cantidad fija: la media de las recaudaciones obtenidas durante el último decenio.(175) Y en la segunda mitad del siglo XV también Albatera estableció concordias temporales con los arrendatarios, pagando 12 timbres anuales por todo el señorío y, posteriormente, 18 ó 20 , al crecer ostensiblemente su población con ocasión de los bandos en los que participaba el señor.(176) De no aceptar este tipo de alternativa, los arrendatarios sólo podían evitar el fraude en los señoríos a costa de incurrir en gastos suplementarios de vigilancia y control -o subarrendando allí la percepción-, como quedó de manifiesto en 1491. Ese año, el arrendatario de la sisa mayor requirió la intervención de los jurados oriolanos para "que compelesquan los carnisers dels dits llochs (Albatera, Cox, La Granja y La Daya) que en los disabtes de cascuna setmana vinguan al dit siser e li manifesten les carns e peix e oli que hauran mort e venut e ab efecte li paguen la sisa de les dites cosses", o bien, "li estimen los pobladors dels dits llochs, e segons ço que poran menjar que pagara de sissa per tot lo any".(177) Como era de prever, los jurados optaron por la primera alternativa, determinando que todos los que vendieran artículos sisados en los señoríos lo manifestaran semanalmente al arrendatario. Pero al ser notificada esta provisión en Albatera, el señor respondió recordando antiguas concordias y alegando que, en caso de que se pretendiera un seguimiento diario de la venta de carne, corresponđía al arrendatario poner carnicero a su costa; obligación que éste se negaba a asumir.

El sistema de concordia o encabezamiento, introducido probablemente por los arrendatarios por razones de comodidad y simplificación recaudatoria, favorecía a los señoríos -con tal de que se perpetuase- en coyunturas de crecimiento demográfico y podía sentar precedentes de cara a futuras reclamaciones. Durante la primera mitad del Quinientos esta práctica debió generalizarse, además, en todos los señoríos. En 1549, cuando el arrendatario de la sisa mayor pretendió subarrendarla en los 
señoríos -acogiéndose a la letra de la escritura correspondiente, que, por tradición, venía contemplando expresamente su recaudación en toda la general contribución, con excepción de Guardamar-, los titulares de Albatera, Redován y La Daya alegaron ante el Gobernador, con éxito, antigua posesión de no contribuir más que con 10 libras al año en el primer caso, y 3 en los restantes.(179) Al ver truncadas sus expectativas, el arrendatario pidió entonces a la ciudad una rebaja en el precio de remate, induciéndola de este modo a instar pleito en la Real Audiencia contra las pretensiones señoriales. En su negativa a reconocer los supuestos encabezamientos, alegaba Orihuela que, en todo caso, habrían sido establecidos por antiguos arrendatarios de la sisa, pero no por la ciudad. Como la resolución del tribunal valenciano también le fuera desfavorable, el arrendatario se retuvo entonces, motu propio y sin consentimiento alguno, una parte del precio del arrendamiento -9.000 sueldos de un total de 49.800- para resarcirse, provocando ahora nuevo pleito en su contra por parte de Orihuela. Mientras tanto, las autoridades urbanas se enfrentaban entre sí sobre la oportunidad de apelar las provisiones de la Audiencia favorables a los señoríos y, muy en particular, la referente a Albatera, por ser el más poblado -se le calculaban unas 200 casas. La indefinición acerca de las obligaciones concretas respecto al pago de la sisa había arrastrado a la ciudad, pues, a tres conflictos distintos en un mismo año: contra los señores que alegaban antiguas concordias; contra el arrendatario, que se consideraba defraudado; y contra el sector más realista del consistorio, que prefería rendirse ante la evidencia a contìnuar pleiteando inútilmente. La causa contra Albatera proseguía en 1553, sin que, al parecer, se consiguiera alterar su sistema de contribución, fijado por la costumbre en un cupo de 10 libras anuales.(180) Y lo mismo debió ocurrir en los restantes señoríos, cuyas aportaciones a la sisa mayor había establecido la tradición en 3 libras para Redován y Cox, un florín para La Daya, y media castellana -13,5 sueldos- para La Granja.

Si la tentativa ensayada en 1549 para recuperar un ámbito fiscal irremisiblemente mermado acabó fracasando, la misma suerte corrieron ciertas reclamaciones planteadas en 1606. Ese año, al igual que venía ocurriendo desde tiempo atrás, la sisa del pan se arrendó por separado de la sisa mayor, aunque originariamente formaba parte de ella. Pero el arrendatario pretendió ahora recaudarla en los señoríos, provocando así la oposición y el recurso a los tribunales por parte de los titulares de Cox y de La Granja y del panadero de La Daya.(181) Todos ellos alegaron con éxito que las obligaciones fiscales de sus respectivos lugares con respecto a la ciudad estaban encabezadas a perpetuidad en una cantidad fija en concepto de sisa mayor, que incluía la del pan. Y aunque la ciudad, naturalmente, hizo causa común con el arrendatario, tuvo que acabar cediendo ante los testimonios presentados por la parte contraria: antiguos arrendatarios que, relatando su propia experiencia, corroboraban las alegaciones de los señores.

En realidad, cualquier tentativa que cuestionara la vigencia de esas antiguas concordias estaba condenada al fracaso mientras se mantuviera en el ámbito de la sisa mayor. Pero ¿sucedería lo mismo en el caso de que la ciudad tuviera que recurrir a la creación de nuevas sisas?. Tal posibilidad no debió contemplarse más que 
excepcionalmente hasta finales del XVI, pues las posibles modificaciones de algunas tarifas concretas parecen quedar subsumidas hasta entonces en la sisa mayor.(182) Pero en 1569 un estatuto real suprimió la tradicional autonomía de la ciudad para acrecentar o imponer nuevas sisas, estableciendo que, en caso de ser necesarias en adelante, debían contar con aprobación expresa del Virrey, previa indicación de la causa justificativa y destino concreto. Esta exigencia propició que las nuevas imposiciones que se autorizaran en adelante, se arrendaran por separado como algo distinto e independiente de la sisa mayor.(183) En consecuencia, los litigios con los señoríos se centrarán fundamentalmente, a partir de entonces, en torno a sus obligaciones respecto a las nuevas contribuciones.

Así, cuando en 1591 Orihuela obtuvo permiso para imponer durante diez años la sisa denominada de la molienda, hay constancia de que al menos dos señores -el de Cox y el de Albatera- se opusieron a su recaudación en sus dominios, iniciando pleitos en la Audiencia. La nueva sisa había sido autorizada para redimir censales cargados por la ciudad para la provisión del pósito de granos, en un ejercicio que resultó especialmente ruinoso. Y puesto que, según aquélla pretendía, todos los lugares de su general contribución acostumbraban proveherse del granero urbano, era justo que contribuyeran también a financiar su quiebra. Estos argumentos debieron surtir efecto ante la Audiencia, a juzgar por la sentencia publicada en 1593 contra las pretensiones de la señora de Cox, pero en 1597 aun continuaba el proceso contra Albatera, sin que la ciudad hubiera conseguido en los cinco años precedentes recaudar la molienda en este señorío.(184) E ignoro si lo hizo con posterioridad.

Cuando en 1602 expiró el plazo otorgado, no por ello cesó la percepción de esta sisa, ahora destinada, también por un decenio, a cubrir un servicio extraordinario de 12.000 libras concedido por la ciudad a la Corona.(185) Nuevamente, se pretendió que los señoríos contribuyeran, oponiéndose a ello al menos los de Cox, La Granja y Albatera. Pero, aunque al año siguiente se informaba desde Valencia que "los sindichs dels llochs de la contribució apreten lo negoci de que no dehuen contribuhir en lo dret de la molienda, per haver ells també servit a Sa Magestat", la sentencia correspondiente debió ser favorable a Orihuela. Así se deduce de cierta petición de rebaja del precio de remate y refacción de daño presentada a la ciudad por el arrendatario de dicha sisa en octubre de 1609, invocando las pérdidas sufridas en Cox, Albatera, La Granja, Redován y Benejúzar con motivo de la expulsión de los moriscos residentes en dichos señoríos. Petición que, al menos parcialmente -pues exageraba los perjuicios-, le fue admitida por la ciudad.(186)

En 1614 Orihuela recibió nueva autorización para continuar recaudando la mencionada sisa, con tal de que se aplicara exclusivamente a resarcir a la hacienda local del elevado coste financiero que le estaba ocasionando la extinción de la falsa moneda -los menuts adulterins- circulante en su ámbito territorial y cuya requisa había sido ordenada en todo el Reino.(187) Como era de prever, cuando la ciudad trató de hacer efectivo su cobro en los señoríos, sus titulares acudieron de nuevo a los tribunales. El de Albatera, por ejemplo, precisaba en 1616 que sus vasallos habian tenido que hacer frente, mediante tacha vecinal, a 65 libras y 18 sueldos en diners rohins hallados en 
sus dominios y entregados directamente en Valencia, junto a otras 98 libras, 2 sueldos y 8 dineros en ramellet vells -moneda buena. Orihuela, por su parte, aducía su condición de centro comercial respecto al entorno señorial y, en consecuencia, los perjuicios que esta situación la había ocasionado como receptora de moneda adulterada desde antes de decretarse su prohibición y extinción. Los argumentos de la ciudad, sin embargo, debieron sucumbir en esta ocasión ante las pretensiones señoriales, cuyas alegaciones eran similares a las de Albatera. Ese mismo año la Audiencia sobreseyó, a favor de los señoríos, las causas pendientes sobre la contribución en el detecho de la molienda. E, inmediatamente, el arrendatario de dicha sisa solicitó y obtuvo de Orihuela rebaja del precio de remate y refacción de daño al no poder recaudarla en Albatera, Cox, La Granja, Benejúzar y La Daya. Unicamente Redován, cuya reconversión monetaria tomó a su cargo la ciudad, quedó al margen de la exención.(188)

Transcurrida la prórroga otorgada en 1614, la sisa de la molienda no se extinguió, sino que acabó por convertirse en una renta ordinaria y perpétua de la ciudad, destinada a sostener el galopante endeudamiento municipal.(189) Así pues, sin una causa más concreta que justificara ahora su exacción, dada la acumulación de factores concurrentes en el deterioro de las finanzas urbanas, habría de resultar ya prácticamente imposible hacer contribuir a los señoríos en dicha sisa. La ciudad, sin embargo, no renunció a intentarlo, pues en 1626 llevaba pleito con aquéllos por dicho motivo.(190)

A diferencia de la sisa de la molienda, un buen número de contribuciones también de reciente o inmediata creación, autorizadas por los Virreyes entre el último cuarto del XVI y la mitad del XVII, ni siquiera se trató de recaudar en los señoríos, probablemente por entender la propia ciudad que su motivación y destino les eran ajenos.(191) Así pues, la importante escalada fiscal experimentada por la urbe durante este periodo apenas afectó a los señoríos, cuyas aportaciones volvieron a situarse muy pronto en aquellas cantidades fijas -ya meramente simbólicas- establecidas por la costumbre. Este sistema, además, también fue implantado en los dominios de reciente colonización alfonsina, una vez transcurrido el periodo de exención. En 1637, por ejemplo, la ciudad ya solo aspiraba a que se hicieran efectivas las 10 libras de Albatera; y 3 de cada uno de los siete señoríos restantes: Cox, Redován, La Granja, La Daya, Benejúzar, Benferri y La Puebla.(192) E incluso es probable que, con el transcurso de los años, ni siquiera consiguiera recaudarlas con la debida regularidad. Así, cuando en 1666 la ciudad expresó sus quejas a la señora de Albatera por haberse negado sus vasallos a pagar las 10 libras acostumbradas a los arrendatarios de la sisa mayor, ésta contestó -desde su residencia de Bétera- que jamás habia oido hablar de tal obligación durante los 18 años que frecuentaba Albatera.(193)

Naturalmente, Orihuela no podía renunciar a este derecho, pero es difícil saber si los arrendatarios de la sisa mayor trataron de hacerlo efectivo en todo momento, como era su obligación. Quizá para evitar esta posible dejación, la ciudad optó en alguna ocasión por su percepción directa en los señoríos, en vez de dejarla en manos del arrendatario. Así sucedió, por ejemplo, en 1675, al anotarse como cargo del clavario -en asiento contable distinto e independiente al del precio de arrendamiento de 
la sisa mayor- la cantidad de 10 libras a pagar por Albatera, 3 por La Granja y otras 3 por Cox, sin más mención a los restantes señoríos.(194)

La insistencia de la ciudad en preservar sus derechos fiscales habría de quedar nuevamente formulada con ocasión de la creación del señorío alfonsino de Formentera, en 1691. Habiendo sido informada de que "en una de las capitulaciones del nuevo establecimiento de tierras y casas que ha hecho a los nuevos vecinos se previene de que todas las sisas y demás regalías fuesen del señor", la ciudad objetó "que dichas sissas o imposiciones tocan y pertenecen a esta Ciudad, pues...dicho lugar, antes alquería, está dentro de la huerta y término de esta Ciudad y por consiguiente es uno de los lugares de su contribución, como también aquí hay otros lugares que son asímismo de su contribución y, con efecto, pagan cierta cantidad annua por concierto".(195) Pero este planteamiento no era enteramente correcto, pues los derechos fiscales de la ciudad en los señoríos eran independientes y, en consecuencia, no obraban en perjuicio de los que se arrogaban los señores sobre sus vasallos; y viceversa.(196) En realidad, Orihuela ya solo podía aspirar, en el mejor de los casos, a que se reconociera su derecho a percibir una cantidad anual de los nuevos señoríos, sin que sea posible determinar si tal pretensión llegó a prosperar en todos los casos.

La emancipación de los señoríos con respecto a los tributos urbanos, aun no siendo completa, hacía tiempo que se había impuesto en la práctica y contribuye a explicar la profusión de inicativas colonizadoras y su éxito relativo, especialmente a medida que se intensificaba la presión fiscal en la ciudad. La parcial liberación de la órbita fiscal urbana hizo más soportable, sin duda, el peso de las exacciones señoriales y de las propias contribuciones vecinales internas -previsiblemente muy ligerasque recaían sobre los vasallos. De ahí el interés que siempre mostraron los señores por conseguir la exención para sus dominios. Y, al mismo tiempo, las quejas expresadas por la ciudad ante una práctica que se iba generalizando con el tiempo, consistente en la afluencia de población urbana hacia las tiendas señoriales en busca de alimentos más baratos.(197)

$\mathrm{Si}$, a efectos fiscales, cada vez resultó más difícil de justificar la consideración de los señoríos -alfonsinos y baronales- como meras calles de Orihuela, la política urbana en materia de abastecimientos también encontró, cuando trató de aplicarse en los dominios señoriales, algunos obtáculos que acabaron limitando su alcance efectivo. Concretamente, y en relación al alimento básico por excelencia, las autoridades municipales oriolanas tenían la facultad -al igual que sucedía en otras ciudades- de prohibir la saca de granos e incluso de inmovilizar las cosechas, tras hacer recuento, para facilitar el aprovisionamiento del vecindario y, desde que entró en funcionamiento la cámara municipal, garantizar su acopio en función de las necesidades previstas. Asímismo, en caso de que la cámara hubiese acumulado excesivo trigo en relación a la demanda efectiva, gozaban de autoridad para forzar a los panaderos a abastecerse exclusivamente de ella o a recibir las cantidades que se le repartiesen.(198)

En ambas circunstancias, la delimitación del ámbito sometido a este intervencionismo no carecía de importancia, pues -al margen de cualquier consideración 
estrictamente económica- podía tomarse como un elemento indicativo del alcance territorial de la jurisdicción urbana. No en vano, los privilegios de universidad obtenidos por los lugares realengos de Callosa y Almoradi contemplaban expresamente capítulo 5- la facultad para constituir cámara propia de granos, tasar los precios y hacer repartos vecinales.(199) Y, aunque no se menciona el tema de la inmovilización de cosechas -el denominado secrest e inhibició dels forments-, la práctica subsiguiente revela que la autoridad de Orihuela a este respecto sólo alcanzaba, en dichos términos municipales, a las cosechas producidas por vecinos de la ciudad.(200)

En los señoríos, sin embargo, la indeterminación de sus relaciones con la jurisdicción urbana propició que se llegase a situaciones a veces contradictorias y arbitrarias; y, en consecuencia, potencialmente conflictivas. Así, en caso de ordenar la ciudad una inmovilización o secrest de cosechas, no era infrecuente que se incluyera el grano perteneciente a determinados señores -o a los arrendatarios de sus dominios-, si eran vecinos de Orihuela. Tal ocurrió, al menos, con los señores de La Daya en 1400,1421, 1435, 1593 y 1628; y con el señor de Daya Vieja en 1571, lo que originó alguna que otra tensión.(201) Concretamente, la disposición de 1593, que incluía la prohibición de saca, fue incumplida al mes siguiente por el arrendatario de La Daya, al conseguir vender a la villa de Elche un total de 200 cahices, pero sólo tras haber obtenido del Virrey licencia expresa para llevar a cabo la operación, circunstancia que motivó una lógica exposición de agravios por parte de Orihuela.(202) Y en 1571 tuvo que intervenir el Gobernador para tratar de doblegar la actitud del señor de Daya Vieja, que apeló a la Real Audiencia.(203)

A diferencia del caso anterior, el trigo cosechado por los vasallos de señorío no parece que estuviera comprendido normalmente en las inhibiciones decretadas por la ciudad, quizá por la insignificancia de tales existencias a título particular.(204) Aunque, en circunstancias extremas, sí llegó a incluirse. Así ocurrió, por ejemplo, con respecto a Albatera durante la carestía de 1435 y la peste de 1508.(205) Y en 1571 hay constancia de que la cámara de Orihuela realizó compras forzosas a los moriscos de La Granja.(206) En varias relaciones de grano secuestrado por la ciudad, correspondientes a 1581, 1593 y 1628 no figura, sin embargo, partida alguna procedente de los vasallos de señorío.(207) En cualquier caso, el tema no parece que suscitara instancias ante los tribunales.

Sí lo hizo, en cambio, la pretensión oriolana de forzar a los panaderos de los señoríos a abastecerse del granero urbano cuando los excedentes acumulados tenían difícil salida o un precio excesivo. En 1572 el señor de La Granja parece que se limitó a protestar formalmente ante la ciudad por haber obligado a sus vasallos a comprar trigo de la cámara, así como por las requisas efectuadas durante el año anterior.(208) Pero en el invierno de 1614-15 el señor de Albatera pleiteó ya con Orihuela, oponiéndose a las ventas forzosas que ésta pretendía realizar en sus dominios, al igual que en los de Cox, La Granja y Redován. Aducía el señor que, en épocas de escasez, la cámara urbana se había negado a vender trigo al panadero de Albatera, con el pretexto de que era obligación del señor constituir cámara propia para el abastecimiento de sus vasallos.(209) 
Arbitrariedades y contradicciones en la política municipal de abastecimientos no eran, en efecto, inusuales y alimentaban el clima de incertidumbre respecto a los derechos y obligaciones de los señoríos en esta materia. En 1593, por ejemplo, las autoridades oriolanas prohibieron la venta de grano de la cámara urbana a los moriscos de Cox, La Granja y Albatera, expresamente considerados como forasteros,(210) mientras que en 1596 y 1602 alegaban y certificaban que era costumbre de los señoríos abastecerse en el granero de la ciudad cuando tenían necesidad de trigo, por estar incluidos en su general contribución.(211)

Seguramente, la polémica desatada durante estos años no era ajena a las tensiones suscitadas en torno al ámbito de aplicación de las sisas; y, más concretamente, a la de la molienda. En el caso de Albatera se añadía, además, el contencioso que se venía manteniendo acerca de la jurisdicción criminal. Pero a medida que se avanzaba hacia una clarificación -en la práctica- de las obligaciones fiscales de los señoríos, conforme nos adentramos en el Seiscientos, también parece que lo hicieron las referentes al aprovisionamiento de granos. A partir de la década de 1620 -cuando no antes- el radio de acción de la cámara municipal, en caso de poner en práctica medidas compulsivas, ya no llegaba a los señoríos.

\section{Litigios sobre pastos y amprius}

Al igual que ocurría con los distintos derechos que se vienen considerando, el dominio sobre los pastos, montes y terrenos incultos en general también tenía una trascendencia que iba más allá de su mera traducción económica como fuente inmediata de recursos. Además de proporcionar renta a su titular o productos naturales de diversa índole a los más directos usufructuarios de amprius, la forma concreta que asumía ese dominio no era ajena, en efecto, al alcance -espacial y jurídico- de un ámbito territorial; de ahí el carácter litigoso que frecuentemente tuvo. Como elemento conformador del territorio, la propia asignación de límites concretos a estas zonas era lógico que se convirtiera en objeto de conversia entre sus titulares limítrofes, siempre interesados en ampliarlos a costa del vecino. Pero no es este típico conflicto por delimitación territorial el que ahora más interesa, aunque a veces remite al que sí ha de ser objeto de especial atención: el suscitado por el alcance de los derechos ejercidos por los señores sobre las hierbas y amprius existentes en sus dominios.

Puesto que no es el momento de detenerse ahora, dada su complejidad, en el análisis de las diversas formas de dominio, derechos y aprovechamientos que confluían sobre los espacios no cultivados del término general oriolano, baste señalar que en los problemas habidos con los señoríos estaban en juego fundamentalmente dos cuestiones. En primer lugar, la potestad de los señores para arrendar las hierbas de sus dominios, reconocida genéricamente por un fuero de 1403 , no siempre fue acatada sin más por la ciudad; ni siquiera con las propias limitaciones recogidas en el texto foral y en otras disposiciones afines que salvaguardaban los derechos del vecindario sobre el libre uso de los amprius.(212) Si Orihuela discutió, a veces, este derecho señorial, mayor fue la oposición desplegada contra las tentativas señoriales de culminar la privatización de 
sus dominios mediante su conversión en dehesas o vedados. Esta última modalidad conllevaba la potestad de disponer libremente y de forma exclusiva y prohibitiva de los recursos naturales, pudiendo impedir la entrada a cualquiera para su uso.

Dadas sus especiales connotaciones, el derecho de vedado sólo podía ser ejercido por expresa concesión regia, según fueros de Jaime I. Pero la práctica revela, en éste como en tantos otros aspectos, que, en ausencia del privilegio acreditativo, la costumbre y la posesión inmemorial también obraban sus efectos. Además, aunque es un tipo de argumentación escasamente utilizado, los señores también podían reclamar la condición de boalares para sustraer su aprovechamiento a todo el que fuese ajeno al señorío. Solo que, en tal caso, contemplado en fueros, dicho territorio quedaba destinado al abastecedor de la carnicería señorial y al ganado mayor de los vasallos de forma gratuita, sin posibilidad de ser arrendado.

Entrando ya en el desarrollo concreto de los litigios sobre el tema, noticias referentes a época medieval prueban que la condición de vedado no se circunscribía únicamente a los señoríos, sino que también se extendía a otros patrimonios particulares que no alcanzaban categoría jurisdiccional alguna. Más aun, la mayor parte de los señores jamás pudieron mostrar privilegio alguno que respaldara sus pretensiones; de ahí que Orihuela considerase tales apropiaciones como una usurpación y actuara en consecuencia. En 1361, por ejemplo, la ciudad contradijo un bando de D. Ramón Rocafull en que prohibía entrar a cazar y hacer leña en el campo de su señorío de Albatera.(213) Según el cronista Bellot, en 1404 el mismo señor apresó un carnero de un vecino de Orihuela por haber entrado en sus dominios, lo que motivó la corresponiente protesta de la ciudad, que le propuso un acuerdo amistoso antes de acudir a la justicia. Pero el asunto no debió resolverse satisfactoriamente, pues cinco años más tarde, al repetir el señor la acción anterior, Orihuela volvió a conminarle para que restituyera la prenda "maravillándose de tal novedad en vedar que no pasasen los de Orihuela con sus ganados por el campo de Albatera y peñorarles...y que jamás fue vedado tal paraje".(214)

Y no muy distinta era la naturaleza de la pugna mantenida con el señor de la Daya en $1411,1445,1446$ y 1494 . En todos estos casos el señor se habia negado a permitir que los vecinos de Orihuela y de la aldea realenga de Almoradí se introdujeran en la zona de almarjales de La Daya a apacentar su ganado mayor y a coger carrizo y sosa de forma gratuita, argumentando que era término señorial.(215) Ya en 1386 había alegado estar en posesión de arrendar la recolección de la sosa en sus dominios, mientras que sus actuaciones posteriores revelan claramente su aspiración a la categoría de vedado, exigiendo el pago de un cánon a cualquier intruso o apresando ganado extraño.(216)

Aunque no hay constancia de que los titulares de ambos dominios estuvieran en posesión del privilegio de dehesa o vedado, resultaba difícil impedir que, en la práctica, se comportaran como tales. De este modo, y quizá con el apoyo de la coacción derivada de la jurisdicción señorial, pudieron acumular actos positivos suficientes para fundamentar -en la costumbre- la interesada identificación que tendían a reali- 
zar entre territorio señorial y pleno dominio sobre los amprius. Quizá por ello, con el paso del tiempo la ciudad acabó aceptando los hechos consumados y apenas cuestionó con la convicción necesaria los derechos privativos y prohibitivos que ambos señores se arrogaban sobre el aprovechamiento de sus hierbas y almarjales.

Quienes sí dispusieron de los respectivos títulos acreditativos de dehesa y vedado no tuvieron que temer, por lo general, la oposición de la ciudad. En época medieval privilegios de este tipo fueron otorgados con cierta profusión; pero, sin excepción conocida, sus beneficiarios no ostentaban, en el momento preciso, la condición de señores o, caso de hacerlo, no alcanzaban la jurisdicción alfonsina. Se trataba de propietarios de extensas heredades -quizá antiguas alquerías, en algún caso- ubicadas en los límites de la huerta, o bien de poseedores de cañadas en el campo. Al primer grupo pertenecían las heredades de Benijófar y La Juliana, convertidas en vedados por sendos privilegios de 1459,(217) y probablemente las de Algorfa(218) y Daya Vieja.(219) El hecho de que tres de estos cuatro vedados acabaran transformándose, aun en fechas muy tardías, en señoríos alfonsinos no es, sin duda, casual. En el segundo se incluían un número indeterminado de cañadas, alguna de las cuales, como la de Roca de Togores, remontaba su origen legal a 1327.(220) Todos ellos gozaron, sin excesivas molestias, de la potestad no sólo de arrendar las hierbas, sino de prohibir la entrada a cualquiera que quisiera aprovechar sus amprius.

Además de los casos mencionados, los nuevos señoríos que nacían o resurgían a finales del siglo XV en virtud de su colonización alfonsina -Cox, Redován, La Granja- era lógico que siguieran en esta materia la senda trazada por los más antiguos -Albatera y La Daya-, ambicionando consiguientemente algo más que la mera potestad de arrendar las hierbas. Algunos, como fue el caso de Redován, consiguieron incluso la anexión de amplios terrenos comunales limítrofes -el Fondó u Hondones- para incorporarlos al núcleo originario del señorío, extendiendo así su radio de acción.(221)

Finalmente, otros dos antiguos núcleos feudales que, por el momento, no dieron el paso colonizador tuvieron que conformarse, por dicho motivo, con el arrendamiento de las hierbas; y, aun así, no sin vencer cierta resistencia. En 1491, por ejemplo, en respuesta a una disposición de la Ciudad que exigía presentación de títulos a todo aquel que pretendiera arrendar sus hierbas, el señor de Jacarilla alegó que le asistía la posesión inmemorial al respecto, amén de -cosa incierta- la jurisdicción civil y criminal, por lo que no se consideraba obligado a exhibir más documentos.(222) Y en una situación similar se encontraba por entonces el titular de la heredad de Benferri, pues en 1496 obtuvo sentencia favorable al haber conseguido probar "Io lloch e heretament de Benferri esser cavallería antigua e los senyors del dit heretament estar en posesió y haver acostumat de arrendar lo dret de amprivar e herbajar de dit heretament".(223)

A principios de la edad moderna, por tanto, la privatización de pastos y amprius se hallaba ya en un estado bastante avanzado. Y no eran los escasos señores con jurisdicción alfonsina y baronal los únicos beneficiados; también lo eran, y en 
mayor grado, un buen número de propietarios de grandes heredades de huerta y campo y de cañadas de secano. No todos aquéllos podían contar, ciertamente, con respaldo legal suficiente para prohibir la entrada a los intrusos, aunque en la práctica quienes estaban en condiciones de usar la jurisdicción tenían a su favor un elemento disuario de primer orden que, llegado el caso, no dudaban en utilizar. Como manifestaciones de esa potestad coercitiva -ausente en los poseedores de vedados que carecían de jurisdicción-, la multa, el apresamiento de un animal intruso e incluso su degüello eran penas que los señores solían aplicar cuando interpretaban que se había producido un allanamiento de sus dominios. Tal era, a veces, el origen de algunos pleitos con la ciudad; pero también lo era, mientras no suscitara oposición legal, de la adquisición de derecho por posesión inmemorial.

Continuando una tradición enraizada en el origen mismo de las apropiaciones, los siglos XVI y XVII serán escenario de renovados intentos ensayados por la ciudad para recuperar parte de las hierbas y amprius de su general contribución, así como de algunas tentativas señoriales por consolidar sus derechos en esta materia $o$ ampliarlos territorialmente. Durante el reinado de Fernando II, en que parece reactivarse esta pugna, no faltaron disposiciones favorables a las reivindicaciones de Orihuela. Pero tampoco resultaba fácil ignorar los derechos adquiridos por los particulares; y el propio rey Católico llegó a confirmar alguno.

En 1490, por ejemplo, al haber sido informado desde Orihuela de que algunos particulares "venen eo arrenden, se apropien e ocupen los herbatges dels monts afrontats ab ses heretats y dels saladars e almarjals", D. Fernando encomendó al Gobernador un especial cuidado para que no permitiese tales apropiaciones, pues dichas zonas habían de permanecer "comuns e per al us e ampriu comu e de la cosa publica de la dita Ciutat".(224) En virtud de esta orden real las autoridades municipales decretaron al año siguiente "que nenguns senyors de lochs e alqueries situats en lo terme e orta de la dita Ciutat...no sien osats vendre los herbatges que tenen en los dits lochs e alqueries e en les fronters de aquelles perque les dits herbatges son necessaris a la provisio dels bestiars de laurada e altres de la dita Ciutat e als bestiars asegurats de les carneceries de aquella" y que todos aquellos que alegaran títulos de caballerias, peonías o cualquier otro para poder hacerlo, los mostraran en el plazo de 8 dias.(225) La situación debió reproducirse hacia 1507, pues una real provisión de $\mathrm{Da}$. Germana respaldó entonces la prohibición decretada recientemente por la ciudad para que nadie arrendase las hierbas de la huerta y boalares de Orihuela. Y, como algunos señores y particulares alegaran privilegios en contra, una nueva orden real de 1509 reiteró la disposición anterior, sin exceptuar a nadie por esta vez de su cumplimiento.(226) Todo ello no impidió que, dos años más tarde, Fernando el Católico confirmara al propietario de la heredad de Benijófar el privilegio de dehesa y vedado sobre la misma.(227) En todos estos casos Orihuela justificaba su proceder, tanto en la defensa del libre uso y aprovechamiento comunal, cuanto -fundamentalmente- en las necesidades del abastecedor de las carnicerías, a quien debía facilitarse la mayor extensión posible de pastos gratuitos y cuya salvaguarda redundaba en beneficio del común al influir en los precios de la carne. 
Pero, años más tarde, era la propia hacienda urbana la que trataba de rentabilizar también la ofensiva contra las hierbas privadas. Con los precedentes de 1507 1509 -expresamente invocados ahora- y ante la insuficiencia de los ingresos municipales ordinarios para atender el gasto y las deudas contraidas, en 1535 la ciudad volvió a dirigir sus miras hacia los pastos. Con el doble propósito manifiesto de incrementar los recursos hacendísticos y de abaratar el precio de la carne al consumidor, la ciudad resolvió arrendar todas las hierbas del campo -esperando obtener de ellas unas 400 ó 500 libras- y reservar las de la huerta y boalares para el abastecedor de las carnicerías -juzgando que, de este modo, se presionaría a la baja en las pujas sobre el precio de venta de las carnes. Para el éxito de esta doble operación era necesario, naturalmente, recuperar el mayor número posible de pastizales supuestamente usurpados a la ciudad; de modo que se solicitó y se obtuvo provisión real para que ningún señor o particular pudiera arrendar sus hierbas sin mostrar el privilegio acreditativo.(228)

Al menos en esta ocasión la reacción no se hizo esperar, pues prácticamente todos los señores y algunos propietarios de cañadas desenpolvaron sus documentos o firmaron de derecho en la Real Audiencia sobre posesión inmemorial de arrendar las hierbas de sus dominios respectivos. Hay constancia de que así lo hicieron los señores de La Daya, Cox, La Granja, Redován, Benferri y Jacarilla.(229) Con ello se truncaban un tanto los objetivos económicos inmediatos que se había trazado la ciudad. Pero, independientemente de este tipo de repercusiones, la cuestión esencial, aunque no llegara a plantearse entonces de forma explícita, no era exactamente ésa. Y muy pronto habría de quedar en evidencia.

En 1538 el señor de Jacarilla, que continuaba arrendando las hierbas sin oposición alguna, fue denunciado por la ciudad ante el Gobernador cuando trató de impedir el apacentamiento en sus dominios al ganado del abastecedor de las carnicerías urbanas. Alegaba Orihuela que Jacarilla formaba parte de la huerta y de los boalares de la ciudad y, por consiguiente, no se podía vedar el aprovechamiento de sus hierbas a "los moltons que son per a avituallament de la dita Ciutat e que los arrendadors de les carns tenen per a provehir e avituallar aquella".(230) Dos años antes y en íntima relación con la tentativa recuperacionista de 1535 , la ciudad había declarado y reasignado la delimitación tradicional de los boalares y redondas municipales.(231) Y aunque la imprecisión -sobre el terreno- de dichos límites quizá no clarificara suficientemente en qué lado quedaban las hierbas de Jacarilla, su inclusión en el boalar -como pretendía Orihuela- podía no carecer de fundamento; especialmente si se tenía en cuenta la cercanía de Jacarilla respecto al núcleo urbano y las carencias jurisdiccionales que padecía su titular. Sin poder fundamentar la condición de vedado, el simple derecho al arrendamiento de las hierbas no sólo devaluaba su precio de mercado -pues el arrendador tenía que descontar la posibilidad de compartir los pastos- sino que, por otro lado, contribuía a mantener la indefinición territorial de tales dominios.

Ya en 1491, en respuesta a la crida oriolana sobre exhibición de títulos y teniendo en mente las genéricas alusiones del año anterior sobre posibles usurpacio- 
nes privadas de baldios anexos, el señor de Jacarilla se había cuidado de expresar claramente la delimitación concreta de sus dominios.(232) Sin embargo, su reconocimiento oficial mediante la edificación de mojones "de pedra y argamasa" no se produjo, al parecer, hasta 1549 , en ejecución de una sentencia de las propias autoridades urbanas que anticipó un amojonamiento general de todo el boalar oriolano ahora sí suficientemente detallado, mediante 16 mojones- al año siguiente.(233) De cara a las pretensiones de la ciudad, el amojonamiento de Jacarilla apenas podía favorecerle, pues equivalía a reconocerle la posesión de término propio; circunstancia que, a su vez, facilitaba una interpretación restrictiva acerca de su uso y aprovechamiento -y aun de cierto nivel jurisdiccional- en beneficio de su titular. Cuando años más tarde las autoridades oriolanas tomaron conciencia de las implicaciones de dicho amojonamiento, el conflicto se hizo, pues, inevitable.

En 1567, en efecto, el síndico de la ciudad, inmerso por entonces en una ofensiva contra las usurpaciones territoriales acometidas por los municipios limítrofes con Orihuela -Elche, Crevillente, Yecla, Jumilla, Abanilla y Murcia- denunció también

"com lo Magnifich Jaume Togores, Senyor de Xacarella, a obra de una legua mes o meins de la present Ciutat y en mig del terme de aquella té possats uns mollons, volent ab aquells dividir lo terme per ell pretés de la dita heretat del terme de la present Ciutat per a vedar e prohibir que los vehins de aquella ab sos bestiars no entren a pasturar en lo dit amollonat terme".(234)

Puesto que los mojones simbolizaban delimitación territorial y Orihuela no estaba dispuesta a reconocer término alguno a la heredad de Jacarilla -"no tenint aquell, com ab tota veritat no té, terme algú propri que puixa ni deja amollonar"-, se decidió de inmediato destruir los ocho mojones existentes y ordenar a Togores que no osara reedificarlos, bajo pena de 2.000 ducados. Por parte de la ciudad llegó a expresarse, además, el temor a que pudieran causarse vejaciones a sus vecinos en el libre uso de los amprius, de no proceder del modo indicado. Naturalmente, el asuntó acabó en la Audiencia de Valencia, pues Togores esgrimió la sentencia de 1549 para sustentar "que lo dit lloch de Xacarella ha tengut y té son terme determinat".

Ese mismo año, otro incidente producido en circunstancias muy distintas a las que concurrían en el caso mencionado puso nuevamente de manifiesto la vigencia de las antiguas aspiraciones de la ciudad y la complejidad de las implicaciones del dominio sobre las hierbas. A diferencia de Jacarilla, La Daya era el señorío más alejado del núcleo urbano y su titular gozaba -se supone- de la jurisdicción baronal; pero todo ello no impedía que Orihuela continuara considerando el término señorial como incluido en los boalares de la ciudad. Así lo había manifestado en época medieval e incluso, más recientemente, en 1535. Inmersa con singular empeño en la defensa de su integridad territorial y jurisdiccional, en 1567 no dudó, pues, en denunciar al bayle señorial ante el Gobernador por estimar se había excedido en el ejercicio de la jurisdicción, "tant que pasant los moltons de les carniseries de aquesta Ciutat per les terres del lloch de La Daya, jatsia sien terme desta Ciutat, hixque un jorn e feu degolla en aquell, e encara dix paraules prou alterades".(235) Es posi- 
ble, empero, que lo que se cuestionara en esta ocasión no fuera tanto el derecho privativo y prohibitivo del señor sobre las hierbas, cuanto la potestad coercitiva -la jurisdicción- para hacerlo cumplir en el ganado del abastecimiento urbano. Esta interpretación, que podría hacer pensar incluso en un régimen diferenciado, por excepcional y privilegiado, de este tipo de ganado con respecto a los restantes usos comunales y amprius en territorio señorial, vendría sugerida por la declaración de un testigo acerca de las hierbas del señorío alfonsino de Redován, en 1582. Interrogado sobre la facultad señorial para arrendarlas y vedar su uso, matizó en su testimonio que "está en record haver vist fer penyores moltes vegades en dit lloch de Redovà per haver entrat bestiar en dit territori de Redovà, y quant al fet de degollar sols una vegada se recorda que lo justicia de Redovà feu una degolla del avituallador de la carn de Oriola, y per dita causa fonch portat als presons de Oriola".(236)

Si lo que se pretendía era negar a los señores -cualquiera que fuese su jurisdicción- el derecho de impedir el apacentamiento del ganado destinado a las carnicerías urbanas, era lógico que los abastecedores de los señoríos trataran de obtener, en justa reciprocidad, libre acceso a la huerta y boalares de Orihuela. Originariamente, el argumento de la mancomunidad de pastos formaba parte, en efecto, de la munición dialéctica de la ciudad; pero si ésta pretendía llevarlo a sus últimas consecuencias, los señoríos también podían utilizarlo en beneficio propio. En 1593, por ejemplo, Orihuela concedió al avituallador de Cox y de La Granja la licencia solicitada para introducir 400 cabezas

"per la orta y bovalars de la present Ciutat e son terme...per ser los pastos comuns, etiam en los termens de Callosa y Almoradi, conforme los priviletgis que tenen de erectio en universitats".(237)

En 1599 era el abastecedor de Albatera quien obtenía lo mismo,

"considerant ses merces que Albatera es del terme de la present Ciutat y que los pastos per als ganados y bestiars de llurs seguretats son comuns, etiam ab les universitats que estan separades de la dita Ciutat, com son Callosa e Almoradi, com se troba dispost per los privilegis otorgats a dites universitats".(238)

Y en 1607 los ganaderos abastecedores de La Daya y de Redován también elevaron idéntica petición, obteniendo siempre la correspondiente licencia de Orihuela. (239)

Ciertamente, los mencionados privilegios de segregación de Callosa y Almoradí -de 1579 y 1583, respectivamente- establecían -en su capítulo 16-

"que los termens generals de la ciutat de Oriola e Callosa (o Almoradi) sien e resten com huy son comuns per a tots los vehins y habitadors de Oriola e de Callosa (o Almoradi) y de tots los altres llochs que estan situats dins los dits termens generals de Oriola per a pasturar, amprivar e servirse de aquells, segons que fins ara se ha practicat y se practica...".(240)

Pero esta mancomunidad, presuntamente vigente en el campo y en los boalares no privatizados en régimen de vedados, era de dudosa o nula aplicación en la huerta. Así, al objeto de alejar el ganado de los cultivos, el capítulo 31 de la reforma esta- 
tutaria municipal promulgada por Felipe II en 1568 había dispuesto -contra el parecer de la ciudad- "que ningun bestiar de ningun genero que sia puixa anar per la horta de la dita Ciutat...excepto que el avituallador de la Ciutat puixa portar per la dita horta fins en doscents moltons per a servici de la carnicería".(241) Naturalmente, la limitación establecida no siempre era respetada en la práctica, e incluso las propias autoridades urbanas llegaron a permitir su trasgresión de forma expresa mediante la concesión de licencias a ganaderos particulares. Por otro lado, los mismos estatutos de 1568 confirmaban la asignación de determinadas zonas del campo -las redondaspara su explotación por la hacienda municipal, reservando otras -los realengos- para el aprovechamiento comunal.(242) A la luz de esta diferenciación tripartita de zonas con distinto régimen de aprovechamiento, podía interpretarse que la mancomunidad mencionada en los privilegios de universidad quedaba relegada exclusivamente a los realengos. Pero entonces podía surgir el problema de cómo catalogar a los boalares, sorprendentemente ignorados en la clasificación de 1568. Dada la imprecisión reinante, se comprende que los avitualladores señoriales que trataban de acogerse al argumento de la mancomunidad de pastos no olvidaran protegerse mediante la obtención de permisos expresos de las autoridades urbanas.

Los estatutos de 1568 , conviene recordar, se fraguaron y promulgaron en unos momentos de especial sensibilidad por parte de Orihuela respecto al tema de las hierbas señoriales $y$, en general, de las supuestas usurpaciones territoriales. No ha de extrañar, por tanto, que tales preocupaciones quedaran reflejadas en la normativa resultante, que tenían rango de privilegio real. Así, el capítulo 32 disponía

\begin{abstract}
"que ningu vehí ni habitador de la Ciutat de Oriola ne ses hortes sia osat vendre herbatge algú, així en la horta com en lo seca, sino lo que tendrá privilegi pera poderlo vendre, lo qual haja de mostrar dins deu dies aprés de la publicasió del present capitol y se haja de declarar per lo dit Governador ab injunció del Sindich y nostre Procurador Fiscal sobre la validitat del dit privilegi".(243)
\end{abstract}

La nueva revisión de títulos que ello comportaba afectaba fundamentalmente a los propietarios de dehesas y vedados ubicados en el término realengo, pero dificilmente podía entenderse que incluyera también a los señores de lugares con jurisdicción. La duda, una vez más, podía suscitarse en el caso de aquellas antiguas infeudaciones cuyos titulares habian perdido, con el transcurso del tiempo, el ejercicio efectivo de la jurisdicción pero continuaban arrendando sus hierbas. En tal situación se encontraban, por ejemplo, Jacarilla y Benferri. Y, en efecto, en ambos casos se sustanciaron de inmediato pleitos ante el tribunal de la Gobernación.

La sentencia relativa a Benferri, dada el 17 de marzo de 1569, se basaba en otra anterior, de 1496, y en la posesión inmemorial para reafirmar a su señor en la potestad de arrendar las hierbas

"ab la desssus dita modificació et non aliter, que los vehins e habitadors de la dita ciutat de Oriola e avitualladors e no altres puxen amprivar ab llurs bestiars de llauro e de la seguretat en dit heretament de Benferri e llur territori, no obstant lo desus dit real privilegi (de 1568)".(244) 
Pocos años más tarde, en 1582, el propio señor argumentaba al tratar de explicar el origen de su posesión inmemorial y el sentido de dicha sentencia "que la dita heretat de Benferri era cavallería antiga y solía ser lloch y tenía son terme", "lo qual (lloch) fonch derruhit en les guerres propassades y conforme a justicia gozen les dites heretats dels privilegis, prerrogatives y preheminencies que lo dit lloch solía tenir y gozar; y tenen privilegis, entre altres, de poder vendre los herbatges".(245)

En el pleito sobre la hierbas de Jacarilla, reiniciado también en 1569 -pues enlazaba con el los mojones-, la sentencia publicada el 11 de agosto de 1571 era prácticamente similar. Con la posesión inmemorial a su favor, el señor vio nuevamente confirmado su derecho a continuar arrendando las hierbas "ab modificació que los vehins habitadors de la present Ciutat e avitualladors puixen amprivar ab llurs bestiars de llavó e de la seguretat e avituallament de les carns".(246)

Si las limitaciones contempladas en ambas sentencias, referentes a la salvaguardia de los derechos vecinales, no introducían novedad alguna en el régimen de aprovechamiento tradicional de las hierbas de ambas "heredades", tampoco los señoríos jurisdiccionales conocieron alteración alguna en esta materia a raiz de la disposición de 1568. En realidad, el único pleito sobre el particular que ha sido posible detectar en los años siguientes no se inició hasta 1573. Y lo que en él se dilucidaba no era sino la asignación territorial de un paraje en disputa conocido como los "casals", sobre cuya posesión pugnaban el señor de Cox, por un lado, y la ciudad de Orihuela, como valedora de los habitantes del -por entonces- lugar dependiente de Callosa, por otro. La sentencia del Gobernador, que se hizo esperar hasta el 19 de enero de 1580, estableció claramente que los señores de Cox

"de temps inmemorial a esta part son estats en quieta y pasifica posesió del dit lloch de Coix sots les afrontasions desus dites, venent los herbatges de secans e monts del dit lloch de Coix, impedint, prohibint e vedant y ab clams y captio de penyores que nengú que no fos vasall del dit lloch o tengués llicencia de aquell entrás a pasturar dins lo dit terme y en los casals de dit lloch ab bestiars, ni abeuras en les aygues e cequies de dit lloch".(247)

En realidad, más que los derechos privativos y prohibitivos sobre las hierbas, en el caso de los señores de lugares con atribuciones jurisdiccionales predominaban los problemas relacionados con posibles anexiones y usurpaciones de baldios limítrofes al dominio señorial. Los "casals" de Cox, en este sentido, presentaban un cierto paralelismo con el paraje conocido como "Hortanova" en Redován, una porción de saladares en Albatera y una parte de los almarjales en La Daya; aunque las fórmulas utilizadas para la apropiación señorial fueran distintas en cada caso -como se verá más adelante.

A diferencia de los señores de lugares, los propietarios de dehesas y vedados no podían desentenderse de la revisión de títulos exigida por el privilegio de 1569. Al igual que sucediera con los señores de Jacarilla y Benferri, es posible, pues, que la mayor parte de aquellos trataran de obtener ante el tribunal del Gobernador sentencia favorable a sus derechos. Así ocurrió, por ejemplo, con Gaspar Roca de Togores, quien recibió confirmación para arrendar las hierbas de su dehesa y denunciar a cual- 
quiera que entrase en ella sin su consentimiento, por sentencia del Gobernador de 1 de diciembre de 1569.(248) Tampoco los propietarios de la dehesa tradicionalmente llamada de Cascant debieron tener grandes problemas para continuar ejerciendo su dominio, pues tal como reconocía la propia ciudad años más tarde -en 1593-

"ab diversos privilegis y sentencies donades per lo molt Spectable Senyor Governador y per lo Magnifich Justicia en lo Criminal de la present Ciutat y en grau de appellació per Sa Excelencia y Real Consell de la Ciutat y Regne de Valencia...consta ninguna persona poder entrar a herbejar ni tallar pins en dita deesa sens voluntat y exprés consentiment del dit Magnifich Joan Cascant".(249)

Contrariamente, aquellos simples propietarios de dehesas que, careciendo de títulos suficientes, ignoraron el estatuto de 1568 , se encontraron con graves dificultades cuando la ciudad cuestionó sus derechos. En 1601, por ejemplo, Orihuela entabló pleito contra el poseedor de la extensa heredad de La Torre -a la sazón D. Juan Rocamora, señor de La Granja-, una parte de la cual era de regadío, mientras que la zona de campo restante se pretendía "que serveix de exido y deesa de dita heretat". Alegaba D. Juan que los antecesores en su dominio -Francésç Masquefa y, luego, Jaume Roca- y él mismo habían acostumbrado "vendre y arrendarla, donarla, prohibirla e vedarla a les persones que sens orde de aquell y llicencia volen entrar a herbajar y tallar pins e fer altres coses en perjuhi de dita deesa", presentando testigos que así lo corroboraban. También aducía en su favor una sentencia de la Real Audiencia de 1554, aunque no pudo mostrarla por haberse perdido. Pero la sentencia del Gobernador, de 11 de mayo de 1606, resultó contaria a sus pretensiones, al estimar que no se había cumplimentado la exigencia establecida al respecto en el estatuto de 1568.(250) Y es posible que lo mismo hubiera sucedido con algún otro propietario de dehesa. En 1607 Orihuela llevaba pleitos en la Audiencia de Valencia, por razón de "Ios herbatges de ses heretats", no sólo con D Juan Rocamora -que había apelado-, sino también contra D. Juan Rocafull.(251)

Por esas fechas, además, la ciudad parecía hallarse inmersa en una nueva oleada reivindicativa de mayor alcance sobre los pastos de su entorno, esgrimiendo no ya el estatuto de 1568, sino los antiguos -y manidos- privilegios de concesión de términos. Aunque no ha sido posible concretar mucho más sobre el asunto, así lo sugiere el que en 1608 consiguiera arrancar a la Audiencia una provisión para que los oficiales "dels llochs de Guardamar, de la Daya Nova y altres llochs de la dita contribució, particulars persones de la dita ciutat de Oriola y demés persones perturbants" no la molestasen en "la dita possessió de herbejar, vendre e arrendar les herbes que en los dits llochs están y tenen", reconociéndola como "senyora de totes les herbes de sa horta y contribució".(252) Naturalmente, y a pesar de los términos en que se expresaba, tal providencia no podía entenderse susceptible de aplicación rigurosa, sino unicamente mientras no lesionara derechos adquiridos, pues en caso contrario habría acarreado innumerables pleitos. Es por ello, quizá, que no haya constancia de que se emprendieran acciones legales inmediatas, por parte de señores y particulares, en contra de la mencionada disposición. 
Más aun, durante la media centuria que siguió, prácticamente todos los que venían usufructuando las hierbas de sus dominios en virtud de títulos, sentencias o posesión inmemorial continuaron haciéndolo sin apenas oposición de Orihuela, cuyas pretensiones al respecto parecen remitir. Esta aparente calma procesal quizá no fuera interrumpida, en lo sustancial, ni siquiera a raiz de la situación creada por las colonizaciones alfonsinas de esta etapa. En el caso de Rafal, la inexistencia de pastos y terrenos susceptibles de aprovechamientos naturales, dada su ubicación en pleno corazón de la huerta, podría justificar la ausencia de problemas. Emplazado en el campo, Benferri, por su parte, contaba desde tiempo atrás con sentencias confirmatorias de la posesión señorial de arrendar las hierbas, y aunque su nueva condición jurisdiccional pudo haber sido aprovechada para imponer un régimen de vedado, no hay indicios de que esta situación, caso de producirse, originase pleitos.

Algo más extraña resulta, en cambio, la ausencia de referencias al respecto en el caso de Benejúzar. Aprovechando su ubicación en los aledaños de la huerta $-y$, en consecuencia, confinante con los campos y baldios de Orihuela, siempre tentadores, el titular de Benejúzar se apresuró, nada más iniciada su colonización alfonsina, a solicitar del Monarca "el herbaje de las cañadas que tiene en el Estrecho y Assomada del campo anexos al dicho lugar".(253) Ha de suponerse que lo que se pedía entonces era privilegio de vedado sobre unos terrenos previamente apropiados pero incluidos en término oriolano. La solicitud, sin embargo, fué desestimada(254) $y$, aunque entre los bienes propios del señor contiguos a Benejúzar figuraba, efectivamente, cierta heredad denominada Rambla de la Somada, es difícil saber cómo se aprovechaban sus amprius.(255)

Ahora bien, esa probable remisión de procesos judiciales -que no, necesariamente, de conflictos puntuales- pudo coexistir muy bien con una soterrada pero efectiva usurpación de derechos, mientras se viera favorecida por un control deficiente o por una continuada negligencia de la parte afectada. Cuando, coincidiendo con los primeros síntomas de recuperación económica y demográfica, la ciudad comenzó a interesarse nuevamente por la integridad de su ámbito territorial, las privatizaciones estaban alcanzando ya cotas preocupantes. En 1660 la voz de alarma provino de los arrendatarios de las redondas urbanas, que se quejaban de cómo

"els amos de les cañades de dits termens y dels realenchs impedexen als herbajants entren ab sos ganados en les terres de ses cañades y encara les afiten ab sercos que fan en dites cañades...y a altres les permeten per algunes dadives, lo que ve a ser especie de venda".(256)

Puesto que de permitirse estos cercamientos se ocasionaría "notori perjuhy y detriments als drets propris y rentes de la present Ciutat", se ordenó su derribo inmediato, así como el cese de las prácticas privativas y prohibitivas, tras un reconocimiento sobre el terreno que corroboró la magnitud que estaban alcanzando.

Lo que, en principio, parecía una mera acción defensiva de Orihuela ante potenciales aspirantes a la condición de vedado en el realengo, derivó muy pronto, sin embargo, en un nuevo replanteamiento de los derechos sobre pastos y amprius, y las 
delimitaciones correspondientes, incluyendo a los señoríos. Ya a finales de 1661, el titular de Redován, quizá para curarse en salud, firmó de derecho ante el Gobernador sobre su posesión inmemorial de arrendar las hierbas señoriales, incluidas las de Hortanova y Hondones, y de prohibir la entrada a su libre voluntad.(257) Y a principios de 1663 la ciudad se dirigía al Virrey exponiendo claramente la situación:

"Esta Ciudad, en virtud de diferentes privilegios que le han concedido los Señores Reyes, acostumbra vender las yerbas de su término, con particular prohibición que nadie pueda venderlas sin mostrar título o privilegio particular, $y$, no obstante esta prohibición, algunos caballeros y comunidades venden algunas yerbas, pretendiendo unos que lo pueden hacer porque sus haciendas son término de lugares y otros porque pretenden que son dehesas y que están en costumbre de venderlas. Y si algunos tienen derecho para poderlas vender, alargan esta facultad en mucha parte del término de esta Ciudad y de las yerbas que tiene propias, con gran perjuhicio de sus rentas, porque las que la Ciudad vende valdrán mucho más si los particulares y algunas comunidades no vendieren lo que no es suyo".(258)

Al objeto de que se hiciera justicia sobre el particular, Orihuela solicitaba que se encomendara el conocimiento de las causas que se suscitaran a un letrado de la Audiencia, recusando al juez ordinario en la materia -el Gobernador- "porque la primera persona que pretendemos vende muchas más yerbas de las que tiene en el término de Benferri es Don Gerónimo de Rocamora, Teniente de Gobernador de esta Ciudad y que está hoy exerciendo el oficio, y otros caballeros que hacen lo mismo son personas muy poderosas y muy deudos al Teniente de Gobernador".(259)

Más que los derechos de los legítimos señores y propietarios de vedados, lo que preocupaba a la ciudad era, por tanto, la ampliación de esos derechos a terrenos anexos al núcleo originariamente beneficiario. Además de la mención expresa al caso de Benferri, ese mismo año, en el transcurso de las acciones judiciales emprendidas acerca de las hierbas de Redován, se cuestionó si las hierbas de Hortanova, heredad que los señores habían adquirido e incorporado a su dominio después de su colonización alfonsina, podían considerarse propias del señor. Interrogado, al efecto, sobre "quant se ha de dir que alguna heretat es del terme de algun lloch, y qué es requereix el que alguna partida sea del terme de aquell", un testigo entendía

"que si algú senyor de pobles, viles y altres, tenen algú terme desmembrat del terme dels dits llochs, en aquell fan lo mateix que en lo terme y jurisdictio dels tals llochs, venent les herbes, utilantse del preu de aquelles, fent menjar als ganados que els pareix, possant los clams als que fan el contrari, fent pagar terratges y altres taches als que possehixen les tals terres, en les quals heretats o terres exerceix la mateixa jurisdictió que en son poble".(260)

Aunque perfectamente controvertible -e incluso poco consistente en sí mismadesde un punto de vista jurídico, esa era, sin embargo, la interpretación que la práctica parecía sustentar, pues ni el tema era novedoso, ni su resolución carecía de precedentes. Ya en 1535, la provisión de la Audiencia favorable a los derechos de la señora de Redován se refería expresamente a la "paciffiqua e quieta possessió de vendre les erbes y erbages de aquell e de la dita heretat de Ortanova".(261) 
En 1582, como fuera suscitada nuevamente controversia sobre el particular, el señor utilizó como argumento contrario a la interesada consideración de Hortanova que hacía su oponente como heredad ubicada en término realengo, la posesión inmemorial que le asistía de arrendar y vedar dichas hierbas.(262) Y en 1610 eran los propios vasallos de Redován quienes corroboraban esa práctica.(263) Con todo, jamás fue aclarado si los antiguos propietarios de la heredad de Hortanova habían acostumbrado a arrendar o vedar sus hierbas, o si los titulares de Redován la habían adquirido ya con esa facultad anexa -cosa improbable. En caso contrario, no andaban faltos de razón quienes fundaban la privatización de esas hierbas en una usurpación, por muy legítima que hubiera sido la adquisición de la heredad.

Cuestión no muy distinta a la anterior podía suscitarse, también en los dominios de la señoría de Redován, con el término y las hierbas del Fondó u Hondones. En este caso ni siquiera se trataba de un terreno limítrofe al nucleo señorial originario, sino de un alejado paraje de campo que, al igual que sucediera con multitud de parcelas más pequeñas, bien pudo ser objeto -como afirmaba el cronista Bellot- de donación graciosa por la ciudad, haciendo uso de sus facultades para otorgar baldíos. No obstante, sin mediar concesión real, este origen dificilmente podía explicar por sí sólo las razones de su condición señorial -pues no fue objeto de colonización alfonsina- ni los derechos sobre las hierbas que se arrogaron sus titulares. Y, sin embargo, los propios vasallos de Redován corroboraban a principios del XVII estando bajo secuestro el señorío - ambas realidades, que también se ven confirmadas por una amplia y variada documentación posterior, aunque en ningún momento aparezcan los títulos en virtud del cual se ejercía ese dominio.(264) La misma ciudad de Orihuela, que en 1523 parece que llegó a calificar de usurpación la reciente apropiación de los Hondones, trató de ignorar en más de una ocasión su condición dominical: en 1573, atendiendo algunas de las peticiones formuladas por un total de 15 vecinos que solicitaban lotes de tierra de 200 tahúllas cada uno para su roturación y cultivo en dicho paraje;(265) y en 1578 requiriendo a la señora de Redován para que mostrase en el plazo de 10 dias los títulos en que fundaba su derecho a exigir partición de frutos a un cultivador que había cosechado trigo en los mencionados Hondones.(266) Pese a todo, cuando en 1661-1663 se planteó disputa sobre el derecho a arrendar "les herbes del terme de Redovà, que es la heretat de Hortanova y Ramblar y Fondó de Asp", la posesión inmemorial hacía inclinar la balanza claramente del lado del señor.(267)

La conversión en dominio señorial de terrenos de realengo anexos al núcleo originario también debió alcanzar cotas considerables, con el consiguiente impacto sobre las hierbas, en Albatera, especialmente trás la expulsión de los moriscos. En este caso - $y$ a diferencia del testimonio referente a Hortanova-, los expertos nombrados en 1612 para declarar sobre la delimitación territorial del señorío distinguieron claramente las implicaciones derivadas de la mera propiedad de aquellas otras que cabía deducir del elemento jurisdiccional. Requeridos sobre la asignación territorial de dos zonas limítrofes concretas, ambas propias del señor, precisaron que 
"unes terres se destengueren de les altras en aquesta forma: que de les que estan de la vereda a ponent a exercit jurisdicciò (el señor) per ser de son terme, penyorant als que sense llicencia entraven a herbajar, y estes terres han pagat e paguen terratge de set hu, y en la part dels saladars los a acostumat de arrendar y arrenda; y en les terres appellades del realench no exercia jurisdicció encara que eren sues, ni arrendava les herbes, sino que li pagaven terratge los vasalls, de huit uno, y los saladars realenchs son comuns de tot los vehins de Oriola, Callosa, Catral e altres llochs de aquesta comarea, y així, sens arrendament nengú, los que volien tallaren, segons tallen, dita sosa".(268)

Cultivadas en su mayoría por vasallos moriscos hasta 1609 , las mencionadas tierras realengas anexas al término de Albatera no dejaban de serlo -quería decirsepor el hecho de que pagaran partición de frutos al señor vecino. En las circunstancias en que se formulaba, tal interpretación podía haber sido asumida, como mal menor, por el propio señor; pues, sin más título sobre las tierras en litigio que la pretendida posesión inmemorial de exigir dicho cánon, lo que se trataba de evitar entonces era su incautación por el Real Patrimonio, que las reclamaba para sí como bienes vacantes en realengo.(269) Sin entrar ahora en los interesantes -y violentosderroteros por que discurrió esta polémica, importa señalar que, aunque la sentencia del Bayle -de 10 de noviembre de 1612- declaró su condición realenga,(270) quizá no transcurriera mucho tiempo antes de que pasara a dominio señorial; y no precisamente -a diferencia de otros casos valencianos- en concepto de indemnización por las pérdidas sufridas con la expulsión de los moriscos.(271)

Así, una década más tarde, el propio cronista Mosén Bellot alertaba a la ciudad desde su curato de Catral sobre el peligro que representaba el expansionismo territorial del señor, pues

"ab ser emulo y adversari de Oriola, ha obtés lo que ha volgut y occupat del realench una llegua de terra...que lo almarjal que hui occupa el Sr. de Albatera es realench y aixi mateix, de dret, les pedreres y fonts son realenques, y peñora lo de Albatera als vehins de Oriola que van a la Serra del Molinet a beurar sos ganados y arrancar pedra, y lo que pijor es, que lo any passat occupa don Alonso la sosa a uns pobres de Catral, alegant que tenía donació de la Ciutat, sent tot lo terme de Oriola, clar y no litigós".(272)

Y acababa advirtiendo: "si Vs. Ms. com a pares de la Republica no contradihuen a la ambiciò y codicia dels senyors de la casa de Albatera, tot lo que posseixen també en Catral per compres, herencies y donacions de la Ciutat será terme de Albatera a carrech y culpa dels que ho poden remediar". El escrito de Bellot -que incluía referencias históricas concretas, procedentes de sus propias investigaciones sobre el pasado comarcal- venía originado por la inminencia de un posible amojonamiento de términos. Y no otro fue, precisamente, el expediente al que trató de acudir Orihuela cuando, años más tarde, arreciaron las quejas vecinales por la apropiación señorial de los saladares contiguos a Albatera. Informada, en 1643, de que dichos saladares proporcionaban al señor una sustanciosa renta anual -se hablaba de hasta 400 libras-, se decidió instar amojonamiento porque "dita utilitat la pert la 
Ciutat".(273) Y medio siglo más tarde eran los mismos argumentos -disensiones entre los distintos usuarios de los saladares y pérdidas sufridas en el arrendamiento municipal de la sosa- los invocados por la ciudad para que el señor consintiera en la revisión de mojones.(274)

Si la rentabilidad inmediata para las arcas municipales venía siendo uno de los móviles capaces de accionar los mecanismos de defensa de la integridad territorial urbana, la preservación de los usos comunitarios tampoco podía ser relegada cuando se cernían amenazas crecientes. Durante la década de 1690 la ciudad mantuvo pleito contra el señor de Jacarilla al pretender éste aplicar el régimen de vedado en su antigua heredad, recientemente elevada a la consideración de señorío alfonsino merced a la consecución del mínimo poblacional requerido. La sentencia de la Audiencia, pronunciada en 1695, no hacía más que reiterar lo ya establecido por la jurisprudencia anterior y, más concretamente, por la del tribunal de la Gobernación en 1571.(275) En consecuencia, se reconocía al señor el derecho a arrendar las hierbas -sobre cuya posesión inmemorial había litigado recientemente, en 1662-1664-,(276) pero no a impedir el uso de los amprius a los vecinos de la ciudad. Las reacciones subsiguientes, tanto por parte de Orihuela -que, inusualmente, pregonó mediante bando público el derecho de sus vecinos a amprivar en Jacarilla-, como del señor -que persistía en impedir la entrada, protagonizando algún que otro enfrentamiento, y recurrió ante el Consejo de Aragón-, así como ciertos testimonios aducidos en el desarrollo del proceso permiten entrever, sin embargo, que el señor venía imponiendo, de facto, lo que repetidamente le habia sido negado de iure.

Si en el caso de Jacarilla la sentencia de la Audiencia no alteró los derechos adquiridos por las partes en litigio, tampoco lo hizo en el caso de las hierbas de Redován y Hondones, sobre cuyo régimen de aprovechamiento se pronunció en 1691. Tras cuatro años de pleitos entre la ciudad de Orihuela y el Colegio de Predicadores de la misma, la Audiencia desestimó una vez más la vieja pretensión urbana al respecto, reconociendo al señor la

"quieta y pasifica possessió de prohibir y vedar que persona alguna entre sens sa llicencia a fer lleña, pasturar ganados, ni usar del referit terme (de Redovà), per ser com es propri del Collegi, en lo qual terme recau una partida nomenada los Fondons".(277)

Lejos de resultar contradictorias, las sentencias sobre las hierbas de Redován y Jacarilla, pronunciadas por el mismo tribunal con sólo cuatro años de diferencia, ponían de manifiesto que no bastaba con la jurisdicción alfonsina si no se contaba, además, con títulos o jurisprudencia favorable o, en su defecto, con la posesión inmmemorial, para imponer un régimen de vedado en los señoríos. Es por ello que, en 1700, el señor de Jacarilla solicitara ya directamente de la Corona, en recompensa a sus servicios, privilegio expreso de dehesa y vedado conjuntamente con la jurisdicción baronal "porque uno de los motivos de la Real sentencia es no ser bastante la Jurisdicción Alfonsina del suplicante para calificar el derecho de deesa vedada".(278) 
Ahora bien, aunque la posesión de jurisdicción señorial no era suficiente $-y$ tampoco requisito, como lo prueba la existencia de vedados en realengo- para convertir el derecho a arrendar las hierbas -reconocido en fueros- en otro de carácter privativo y prohibitivo, sí facilitaba, sin duda, esa mutación. El uso de la coacción que aquélla permitía podía dar sus frutos, en efecto, mientras se ejerciera de forma continuada y sin contradicción de parte hasta constituir posesión inmemorial o legítima prescripción. Cuando, en 1692, la ciudad trató de recurrir la sentencia de la Audiencia sobre las hierbas de Redován, esgrimiendo varios privilegios, su abogado la alertó de las escasas posibilidades de éxito, haciéndole ver -entre otras razonesque "es conclusión de regla que los privilegios se pierden no ussando de ellos y más facilmente por el usso contrario, en que no es necessaria prescripción, y quando lo fuere, excede la centenaria del Colegio".(279) Y no muchos años más tarde, en 1700 , en el informe redactado al ser consultada acerca de la pretensión señorial de dehesa y jurisdicción baronal sobre Jacarilla, Orihuela hacía balance retrospectivo de la situación en todo su término general, sin negar sus propias responsibilidades:

"En las infancias de esta Ciudad la honrraron los señores Reyes con término de güerta y campo dilatadíssimo y correspondiente a su numerosa población, en cuyo tiempo tenía este público libres y bastantes todos los amprius. Esta dilatación olvidó a nuestros mayores del sumo aprecio con que se deben mantener los distritos; descuidólos de su conservación y esta negligencia facilitó a la ambición la dilatación de los suyos, estrechando los nuestros... Haviéndose formado la villa de Albatera con jurisdicción baronal, se desmembró del de esta Ciudad más de dos leguas de término de campo y güerta y no contenta la Ciudad con éste, en un amojonamiento que se hizo en la próxima centuria usurpó Albatera más de media legua de tierra que oy será difícil de recuperar, porque ya nos obsta prescripción legítima... A que se añade otra gran parte que se ha desmembrado en los términos de las Baronías de La Puebla y Daya. A que se añade que haviéndose fabricado en esta contribución los lugares de La Granja, Cox, Redobán, Benferri, Rafal, Benexúsar, Formentera, Benijófar y Molins, aunque en sus alquerías tienen muchos vezinos por drecho libre el usso de los amprius necessarios, según fueros, el ser sus dueños poderosos infunde miedo en los pobres y las respetan con más fuerte privación que si fueran legítimos vedados. Con los quales y las deesas que tienen en los campos de esta Ciudad D. Juan Roca, D. Alonzo Rocamora, D. Fortuno Maza, Joseph Pisana, D. Ginés Jofre y Jayme Gallego, se ocupan más de dos leguas de estos campos, quedando los de esta Ciudad tan limitados que apenas quedan señas de lo que fueron... Y estos recelos de que no faltará quien se anime a procurar igual merced nos les advierte la práctica, porque además de estar construiendo un lugar el Cabildo de esta Santa Yglesia, contiguo a Jacarilla, con el ancia de conseguir jurisdicción varonal, no falta quien en sus heredades nuevamente veda los herbaxes, arrancar piedra, cortar leña y hacer cal, estrechando a que los que uviessen de haserlo le pidan licencia, lo que entendemos da auténtica sin duda para que estos actos en adelante o le prueben inmemorial posessión o le den pretexto para entrar en la misma pretención que oy tiene D. Luis".(280)

Esta última descripción correspondía exactamente a lo que en esos momentos trataba de implantar en sus dominios el poderoso Marqués de Rafal. Aunque ya el anterior titular de esta casa nobiliaría había provocado, entre 1679 y 1683, la oposi- 
ción de la ciudad a sus intentos de privatizar las hierbas de determinadas posesiones ubicadas en los campos realengos,(281) parece que fue D. Jaime Rosell quien acometió con mayor empeño la extensión de estas prácticas a los aledaños de sus dominios señoriales. Habiendo concedido la ciudad a sus antecesores, en 1633, el dominio útil de una zona de almarjales -la Majada Vieja- contigua a su baronía de La Puebla, mediante establecimiento a censo con pacto de reducción a cultivo, en 1700 se decidía instar causa de comiso, bajo la acusación de que el Marqués trataba de ejercer allí derechos de dehesa y jurisdicción baronal.(282) Haciendo uso de las facultades inherentes a su dominio directo, Orihuela reaccionaba así a la tentativa de señorialización que comportaba las atribuciones que se arrogaba el Marqués sobre un territorio manifiestamente realengo.

E intentos similares protagonizó el mismo D. Jaime en las dos zonas anexas a su señorío de Benejúzar que, también casi un siglo atrás, otro de sus antecesores ya había tratado de convertir en dehesas señoriales. En 1699, en efecto, procuraba anexionarse un paraje conocido como Estrecho de Soler mediante el consabido expediente de impedir "de facto...fer pedra, cals, alcheps, lleña y el us de altres amprius".(283) Y, no contento con ésto, en 1702 era la otra zona de campo también lindante con Benejúzar, denominada la Asomada, la que trataba de convertir del mismo modo en dehesa señorial, originando la consiguiente oposición de la ciudad.(284) Todas estas situaciones conflictivas generadas por las ambiciones territoriales del Marqués de Rafal, aunque estaban siendo examinadas por el Consejo de Aragón ya en $1702,(285)$ no parece que hubieran quedado resueltas mediante sentencia cuando en 1706 dicho noble encabezó la ofensiva austracista en la comarca.(286)

Sí lo hicieron, en cambio, las pretensiones encontradas acerca de las hierbas y amprius de un paraje no bien delimitado conocido como el Charquero de Cox y vertientes de Callosa, cuyo régimen de aprovechamiento enfrentó a la villa de Callosa y la ciudad de Orihuela, por un lado, con el señor de Cox, por otro. Habiéndose iniciado el litigio a instancias de Callosa en 1698, la Real Audiencia reconoció, por sentencia de 4 de enero de 1704, el derecho al libre uso comunal de este paraje.(287) Puesto que ya en 1580 una sentencia del Gobernador había confirmado al señor el régimen de vedado imperante en los límites de su dominio originario,(288) la nueva sentencia debía referise a una zona anexa, objeto quizá de una tentativa de apropiación señorial. El propio desinterés de la ciudad, que en 1721 reconocía no haber pagado en su momento los derechos de expedición correspondientes para su entrada en vigor,(289) parece confirmar la escasa innovación que representaba dicha sentencia respecto a la situación anterior.

Más que a una ofensiva urbana orientada a recuperar hierbas y amprius señoriales, la serie de litigios que se sucedieron en las últimas décadas de la etapa foral respondía esencialmente a la necesidad de impedir la proliferación de privatizaciones ilegales. En su acción defensiva, el reconocimiento del status quo era, en realidad, lo máximo que la ciudad podía obtener en los tribunales. Y no era poco, a tenor de los resultados que venían produciendo los mecanismos activados por los señores para incrementar la base territorial de sus jurisdicciones. Sin ninguna reconquista 
importante en su haber, la ciudad consiguió, al menos, detener buena parte de las avanzadillas que, desde diversos frentes, venían socavando la integridad de sus hierbas y derechos de amprius. Por otro lado, las colonizaciones alfonsinas que se produjeron durante estos años no plantearon problemas al respecto, a excepción de Jacarilla, porque las bases territoriales que las sustentaban consistían en heredades enteramente de huerta y ya roturadas -era el caso de Formentera y Molins- o llevaban incorporadas desde antiguo el privilegio de dehesa y vedado -como ocurría con Benijófar.(290)

\section{Algunas consideraciones finales}

Aunque hasta el momento no se le haya prestado la atención que merece, la pugna que mantuvieron señores y cabeceras muicipales no cabe entenderla desde una caracterización meramente episódica o accesoria, especialmente de cara a una comprensión de la articulación de poderes en el entramado social e institucional del Antiguo Régimen. Lejos de traslucir una esporádica discrepancia de pareceres sobre tal o cual derecho, las tensiones entre ambas instancias de poder, a veces latentes, quedaron en evidencia en multitud de procesos judiciales -en gran parte aun por descubrir y analizar con detalle-; y su eco estuvo presente, una y otra vez, en no pocas de las reclamaciones expresadas en las Cortes del Reino. Ante tan variadas manifestaciones y dado el carácter recurrente con que se insistía en replantear determinadas situaciones, no cabe sino deducir la existencia de un antagonismo básico de fondo, con calado suficiente como para mediatizar y desvirtuar aquellas otras fuerzas convergentes que pudieran resultar de la natural inserción de este mundo señorial en su ámbito mancomunal o supramunicipal de referencia.

Sin necesidad de invocar términos tan equívocos como el de señorío colectivo para caracterizar el sistema formado por la ciudad y los núcleos satélites, hay que tener presente, ciertamente, que buena parte de los señores llegaron a ser, al mismo tiempo, piezas importantes en el entramado del poder comarcal o territorial mediante su imbricación, bien en las redes del patriciado urbano, bien en las de la administración real. En el primer caso, el que la nobleza tuviese prohibido el acceso a los cargos municipales en todas las ciudades valencianas antes de mediar el siglo XVII, no debe hacer ignorar -además de los vínculos de clientelismo y parentesco, bien patentes en las banderías- que una parte de aquellos señores pertenecía al grupo de los caballeros, cuya representación en los órganos de poder local sí estaba perfectamente regulada.(291) Y en lo que se refiere al segundo, la presencia de señores de este tipo en los oficios superiores de las Gobernaciones y las Baylías -reservados, por lo general, a esta nobleza autóctona de segunda fila- e incluso en la nómina de jueces de la Audiencia, no era nada excepcional, ni siquiera con posterioridad a las quejas por incompatibilidad expresadas en las cortes de 1547 por el brazo real.(292) Individualmente considerados, muchos señores no ocupaban, por tanto, una posición totalmente externa al entramado político urbano ni a la administración regia, sino que eran parte constitutiva de ambos. 
Esa alteridad de los señores, esa capacidad para estar dentro y fuera al mismo tiempo -origen de no pocas contradicciones y causa última de muchas de sus conquistas-, parece desdibujarse, sin embargo, cuando se examina la cuestión desde una perspectiva más amplia y se atiende, precisamente, a las implicaciones derivadas de su condición señorial. En términos económicos, por ejemplo, aunque muchos de ellos desarrollaran actividades o comportamientos -en el mundo del crédito, la especulación comercial e incluso la explotación agraria- próximos a los de patriciado -del que a veces procedían-, desde su condición de perceptores de renta señorial estaban interesados fundamentalmente en romper cualquier atadura procedentes del exterior que interfiriese en sus mecanismos de extracción del excedente. Aligerar a sus vasallos de cargas urbanas, erradicar el intrusismo de ganaderos y recolectores foráneos, anexionar e incorporar terrenos baldios, monopolizar la justicia -con toda su capacidad de presión, amén de los emolumentos correspondientes, por acción o por omisión...-; todo ello contribuía a elevar la renta señorial. Y lo hacía, además, por una vía menos problemática que la que pudiera traducirse en una intensificación directa de las exacciones sobre los vasallos. Así, al hacer recaer el peso de esta forma bastarda de reacción señorial sobre el ámbito externo a sus dominios, los señores se aseguraban la complicidad e incluso la activa e interesada colaboración de sus propios vasallos.

Por contra, esta estrategia señorial dirigida hacia la consecución de una segregación de facto respecto del municipio matriz, al objeto de minimizar la parte de excedente susceptible de apropiación por la ciudad, entraba necesariamente en colisión con la que trataban de desarrollar los sectores mayoritarios del patriciado urbano, en virtud de los imperativos derivados, tanto de sus propios intereses como grupo dominante, cuanto de su condición de representantes del cuerpo social de la ciudad. Estrechamente vinculado a la propiedad agraria y a la especulación comercial, al mundo del crédito, e incluso al oscuro entramado que constituían las haciendas muncipales, el patriciado urbano contaba con una excelente plataforma para la defensa de sus intereses básicos, mediante el control de los resortes de poder inherentes a la institución municipal. Entre otras manifestaciones, ese control le permitía diseñar la política fiscal menos onerosa a sus bolsillos, intervenir ventajosamente el mercado, alejar el ganado de aquellas zonas -la huerta- donde se ubicaban sus propiedades, disponer la concesión de baldios, monopolizar los oficios jurisdiccionales... En este marco de actuación, el patriciado expresaba sus relaciones de dominio sobre la comunidad haciendo prevalecer sus intereses particulares o de grupo. Pero, allí donde confluían las implicaciones de ese dominio con aquellas otras que derivaban de la estrategia señorial, los grupos patricios tampoco podían olvidar que eran ellos quienes encarnaban el cuerpo político de la universitas, cuya integridad -jurisdiccional, territorial, fiscal- constituía, además, uno de los principales sostenes de su privilegiada posición. La oposición patricia a la estrategia señorial resultaba, pues, inevitable en la medida en que su hegemonía sobre el cuerpo social urbano se nutría de la capacidad para mantener en equilibrio los propios intereses con los de la universitas. Y, desde luego, la estrategia señorial no sólo atentaba contra ese equilibrio, sino que contribuía a erosionar los dos pilares en que se sustentaba. 
Naturalmente, el choque entre los dos bloques formados por señores y vasallos, por un lado, y patricios y comunidad, por otro, no excluía la aparición de discrepancias internas en cada uno de aquéllos, derivadas de las relaciones de clase; pero sí debió actuar como eficaz amortiguador. Y tampoco impidió la formación de alianzas horizontales, especialmente en los niveles superiores, merced a esa alteridad del mundo señorial con respecto al sistema urbano. Las propias divisiones internas de los grupos patricios y las banderías urbanas tampoco debieron ser ajenas, finalmente, a esas alianzas.

\section{NOTAS}

1. Aunque en la ya extensa bibliografía sobre señoríos valencianos no faltan referencias a esta cuestión, el único estudio en profundidad, a partir del análisis de la legislación, los tratadistas y la jurisprudencia, se debe a P. PLA ALBEROLA:Conflictos jurisdiccionales en un gran señorío valenciano. El Condado de Cocentaina ante la consolidación del absolutismo, 3 vols., tesis doctoral inédita, Fac. Filosofía y Letras, Univ. de Alicante, 1985.

2. Sobre la jurisdicción alfonsina vid., además de Ibidem, II, ff. 762-993, S. ROMEU ALFARO: "Los fueros de Valencia y los fueros de Aragón: jurisdicción alfonsina", Anuario de Historia del Derecho Español, 42, 1972, pp. 75-115; A. GIL OLCINA: La propiedad señorial en tierras valencianas, Del Cenia al Segura, Valencia, 1979, pp. 16-17; J.M. IBORRA LERMA: Realengo y señorío en el Camp de Morvedre, Caja de Ahorros de Sagunto, 1981, pp. 211-212. En la última década, la bibliografía sobre señorios alfonsinos, más centrada en su vertiente colonizadora, ha crecido considerablemente. Vid. al respecto, en este mismo número de la Revista de Historia Moderna, P. PLA ALBEROLA: "La jurisdicción alfonsina como aliciente para la recolonización del territorio". Rechaza este autor la arraigada identificación de la jurisdicción alfonsina -jurisdicción civil plena y criminal baja- con el mixto imperio y la asimila a un mero imperio incompleto, tradicionalmente reservado para referirse a la jurisdicción baronal -civil y criminal, alta y baja.

3. A falta de un listado o mapa jurisdiccional del Reino de Valencia suficientemente preciso -que tenga en cuenta no solamente su condición de realengo o señorío, sino su categoría jurisdiccional, en ambos casos- hay que seguir acudiendo, como fuente general de información, a M. VICIANA: Crónica de la Inclita y Coronada Ciudad de Valencia, Valencia, 1564 (ed. facsímil Universidad de Valencia, 1972-1983, 5 vols.) y a G. ESCOLANO: Década Primera de la Historia de la Insigne y Coronada Ciudad y Reino de Valencia, Valencia, 1610 (ed. facsímil Universidad de Valencia, 1972, 6 vols.). Además, naturalmente, de la historiografía de carácter local y comarcal.

4. Incluí una cronología indicativa, para la edad moderna, en "Sobre el origen territorial en los señoríos de colonización alfonsina", Congreso Señorío y Feudalismo en la Península Ibérica (ss. XII-XIX), Zaragoza, 1989, (en prensa). Puede verse otra, más reciente y completa, en P. PLA ALBEROLA: "La jurisdicción alfonsina..."

5. D. BERNABE GIL: "Universidades y villas. Notas sobre el proceso de segregación municipal en el realengo valenciano (siglos XVI y XVII)", Revista de Historia Moderna, 6/7, 1986-87, pp. 11-38. 
6. Cobra así pleno significado la categoría jurisdiccional que define a las universidades justamente la alfonsina- y a las villas -la alta criminal. Ibídem.

7. D. DE LARIO: Cortes del reinado de Felipe IV. I. Cortes valencianas de 1626, Universidad de Valencia. Valencia, 1973, p. 24. Sobre precedentes medievales, vid. J. SANCHEZ ADELL: "La Comunidad de Morella y sus aldeas durante la Baja Edad Media (Notas y Documentos)", Estudis Castellonencs, 3, 1983, pp. 73-181.

8. R. GARCIA CARCEL: Cortes del reinado de Carlos I, Universidad de Valencia, Valencia, 1972, p. 200.

9. D. DE LARIO: Cortes...de 1626, p. 103.

10. Transcripción de la sentencia en C. SARTHOU CARRERES: Datos para la Historia de Játiva, Imp. Sucesora de Bellver, Játiva, 1933, I, pp. 409-410.

11. D. DE LARIO: Cortes...de 1626, p. 31.

12. Vid. referencias a litigios concretos en C. SARTHOU CARRERES: Op. cit., I, pp. 407-425.

13. R. GARCIA CARCEL: Cortes... de Carlos I, p. 147.

14. D. DE LARIO: Cortes...de 1626, p. 100.

15. E. CISCAR PALLARES: Las cortes valencianas de Felipe III, Universidad de Valencia, 1973 p. 161 . Sobre la jurisdicción suprema titulo gubernatorio o gubernatorio nomine, equivalente a la del Portantveus de General Gobernador, vid. J.M. IBORRA LERMA: Op. cit., pp. 213-215.

16. D. DE LARIO: Cortes...de 1626, p. 103.

17. Ibidem, p. 132.

18. A. ALBEROLA ROMA: Jurisdicción y propiedad de la tierra en Alicante (ss. XVII y XVIII), Ayuntamiento-Universidad de Alicante, 1984, pp. 456-459.

19. L. TAGELL: Epitome Sententiarum Sacre Regie Audientae Valentine (B.U.V.: ms.), let. 1,352 .

20. LL. GUIA MARIN: Cortes del reinado de Felipe IV. II. Cortes valencianas de 1645 , Universidad de Valencia, 1984, pp. 360-361.

21. Ibídem, p. 283.

22. Vid. referencias en C. SARTHOU CARRERES: Op. cit., pp. 407-423. Sobre Sumacárcer, también E. SALVADOR ESTEBAN: Cortes valencianas del reinado de Felipe II, Universidad de Valencia, 1973, p. 143.

23. E. BELENGUER CEBRIA: Cortes... de Fernando el Católico, pp. 40, 101, 102, 147; E. CISCAR PALLARES: Cortes...de 1604, pp. 78-79; D. DE LARIO: Cortes...de 1626, pp. $125,128-129$

24. E. SALVADOR ESTEBAN: Cortes...de Felipe II, pp. 91-92; E. CISCAR PALLARES: Cortes ... de 1604, p. 82; D. DE LARIO: Cortes... de 1626, pp. 52-53; LL. GUIA MARIN: Cortes de...1645, p. 212.

25. Cit. por E. BELENGUER CEBRIA: "Precisiones sobre los comienzos del virreinato en Valencia durante la época de Fernando el Católico", Primer Congreso de Historia del Pais Valenciano, Universidad de Valencia, 1976, III, pp. 47-53, donde se analiza el contexto político. Un estudio reciente sobre la revisión de títulos de barones, realizada -ahora sí- en todo el Reino de Valencia una década más tarde, y la relación con sus antecedentes, en R. BALDA- 
QUI ESCANDELL: El Registro Real Cancillería 495 del Archivo General del Reino de Valencia. Estudio y edición, tesis doctoral inédita, Universidad de Alicante, 1993, 5 vols.

26. R. GARCIA CARCEL: Cortes...de Carlos I, pp. 202-203.

27. Ejemplos de señores baronales ejerciendo oficios de Gobernador y Bayle, en infra nota 292. Aunque la mayor parte de ellos lo hiciera gubernatorio nomine.

28. J.M. IBORRA LERMA: Op. cit., pp. 213-215.

29. Vid. R. BALDAQUI ESCANDELL: Op. cit., ff. 71-72, y apéndice documental, doc. 44 y 65.

30. Para Morella y Valencia, vid. respectivamente, J. SANCHEZ ADELL: Op. cit., p. 96 y R. FERRERO MICO: La hacienda municipal de Valencia durante el reinado de Carlos $V$, Ayuntamiento de Valencia, 1987, pp. 144-145. Para Játiva y Alcira, infra, notas 31, 32 y 33.

31. C. SARTHOU CARRERES: Op. cit., pp. $414,415$.

32. A. FURIO y F. GARCIA: "La economía municipal de Alzira a fines del siglo XIV según un libro de cuentas de 1380-1381", La ciudad hispánica durante los siglos XIII al XVI, Ed. Universidad Complutense, Madrid, 1985, II, pp. 1.628-1.629.

33. D. DE LARIO: Cortes de 1626, p. 127.

34. LL. GUIA MARIN Cortes de 1645, p. 314.

35. En origen, la peyta es un tributo real sobre la propiedad inmueble de realengo. Para su cobranza, la Corona tendió a fijar cupos fijos y perpétuos a los municipios, que, de este modo, disponían de un amplio margen de maniobra para su recaudación entre los vecinos. Puesto que la cantidad obtenida por el municipio no tenía por qué guardar relación con el cupo anual asignado por la Corona y tampoco era frecuente que se respetaran las exenciones originarias -propiedad noble y eclesiástica-, en la práctica se aproximaba mucho más a una carga municipal que a un impuesto real. Cfr. D. BERNABE GIL: "La fiscalidad en los territorios peninsulares de la Corona de Aragón durante la época de los Austrias", J. I. FORTEA PEREZ y C. M. CREMADES GRIÑAN (Eds.) Política y Hacienda en el Antiguo Régimen, Murcia, 1993, p. 18, nota 8 .

36. Referencias varias en C. SARTHOU CARRERES: Op. cit., pp. 413-424.

37. T. PERIS ALBENTOSA: "Anàlisi crítica i guia metodològica dels cappatrons de la peita de l'Arxiu Municipal d'Alzira", Al-gezira, 1, 1985, p. 113, nota 2; M. RUZAFA GARCIA: "Problemas impositivos entre Alzira y algunos señoríos colindantes (1457-1460)", Anàlisi local $i$ història comarcal. La Ribera del Xúquer (ss. XIV-XX), Diputació de València, 1990, pp. 25-32.

38. D. DE LARIO: Cortes de 1626, p. 58. Alega Penáguila tener la jurisdicción suprema sobre los señoríos de Alcoleja, Benigallim, Beniafé, Ares y Benasau, para obligarles a pagar la peyta.

39. J. SANCHEZ ADELL: Op. cit., pp. 96, 99.

40. Sobre las concesiones jurisdiccionales en este ámbito territorial, vid. J.M. IBORRA LERMA: Op. cit., pp. 217-238.

41. Además de los ejemplos que se aducirán más adelante, referentes a Orihuela, cfr. L. TAGEL: Epítome..., let. S, 172, donde se dice: "sisses impossades per una universitat a la jurisdicció de la qual està subjecte altre lloch, tenentur contribuere los habitadors de dit lloch, maxime quant utilitas collectae respiscit etiam illos".

42. Para Játiva, vid. la petición expresada por el brazo militar para que se respetara esta 
costumbre, en E. CISCAR PALLARES: Cortes...de 1604, p. 161. Para Morella, J. SANCHEZ ADELL: Op. cit., pp. 96, 99.

43. Tal debió suceder en Játiva, ya que en 1583 se sustanció "pleito de la ciudad de Xàtiva contra Ayacor, Estubeny, Anna, Granja, Torrent, Torre de LLorís, Anahuir, Rotglá y otros pueblos de su jurisdicción, sobre la transacción y concordia de 1461 , referente a sisas y otros impuestos que alegan no haber derecho a imponérseles más de lo convenido de medio florín anual por cada una casada, y dos sueldos y medio anuales por cada comedor soltero, según otros detalles convenidos, y que los jurados de Xàtiva querían aumentarles por razón de sisas" (C. SARTHOU CARRERES: Op. cit., I, p. 413). En algunos señoríos del término de Morvedre -Beselga, Estivella, Albalat, Segart- las cartas de repoblación suscritas entre señores y vasallos trás la expulsión de los moriscos no olvidan mencionar la obligaciones fiscales para con la villa -un impreciso "dret vehinal" que "tots temps han acostumat de pagar"consistente en una cantidad fija anual en cuyo pago participa tanto la comunidad de vasallos como el señor. Vid. J.M. IBORRA LERMA: Op. cit., pp. 407, 417.

44. E. CISCAR PALLARES: Cortes...de 1604, p. 160.

45. Furs, I, p. 118. Calificado generalmente como regalía señorial, este derecho suele figurar, en efecto, en las cartas de población o documentos similares en que se regulan las relaciones entre señores y comunidades de vasallos. Si bien, en determinados casos son estas últimas las que lo pretenden.

46. C. SARTHOU CARRERES: Op. cit., I, p. 107.

47. D. DE LARIO: Cortes...de 1626, p. 129.

48. T Cfr. C. SARTHOU CARRERES: Op. cit. I, pp. 102-7. Un caso concreto, en término de Valencia, es profusamente descrito por M. LLOP CATALA: "Proceso contra D. Pedro de Moncada (1416). Apuntes y comentarios sobre el uso de 'aemprius"', Escritos del Vedat, XVII, 1987, pp. 217-252.

49. Menciones varias en C. SARTHOU CARRERES: Op. cit. I, pp. 102-107, y en V. BOIX: Xàtiva. Memorias, recuerdos y tradiciones deesta antigua Ciudad, Imp. Blas Bellver, Xàtiva, 1857, pp. 425-435.

50. Vid. A.R. CANDELA HIDALGO: La extinción del elemento solariego en los señorios de jurisdicción alfonsina radicados en las comarcas del Campo de Alicante y Bajo Vinalopó, tesis de licenciatura, Univ. Alicante, 1992, ff: 605-606.

51. Furs..., lib. I, rub. II, furs IX-XIII.

52. Ibidem. Concretamente, el cap. XIV de dicha sentencia (fur IX).

53. Furs..., Lib. I, rub. II, fur III.

54. El originario privilegio de asignación de términos, dado por el rey Alfonso de Castilla en 1266 (V. MARTINEZ MORELLA: Cartas de los Reyes de Castilla a Orihuela, 1265-1295, Alicante, 1954, pp. 23-26) fue confirmado por Pedro IV de Aragón un siglo más tarde (J.V. CABEZUELO PLIEGO: La Guerra de los dos Pedros en las tierras alicantinas, Instituto de Cultura Juan Gil-Albert, Alicante, 1991, p. 94). Sobre Abanilla, vid. J. TORRES FONTES: El señorío de Abanilla, Diputación de Murcia, 1962; y M.T. FERRER I MALLOL: "Abanilla y Jumilla en la Corona catalano-aragonesa (s. XIV)", Homenaje al Prof. Juan Torres Fontes, Universidad de Murcia, 1987, pp. 477-490. Sobre Crevillente, P. GUICHARD: "Un seigneur musulman dans l'Espagne chrétienne: le ra'is de Crevillente (1243-1318)", Mélanges de la Casa de Velazquez, IX, 1973, pp. 283-334; y V. CABEZUELO PLIEGO: La Guerra..., pp. 45, 56-60, 65-66. En general, vid. P. BELLOT: Anales de 
Orihuela (siglos XIV-XVI), (ed. de J. TORRES FONTES a partir del manuscrito, redactado hacia 1622), 2 vols, Orihuela, 1956; y J. B. VILAR RAMIREZ: Los siglos XIV y XV en Orihuela, Patronato Angel García Rogel, Murcia, 1987.

55. A falta de un estudio en profundidad acerca de las transformaciones operadas en el hinterland rural oriolano durante los siglos XIV y XV, hay que acudir, para hacerse una idea de conjunto, fundamentalmente a los materiales aportados por P. BELLOT: Anales de Orihuela...; J. TORRES FONTES: Repartimiento de Orihuela, Ed. Academia Alfonso X El Sabio, Murcia, 1988; M. T. FERRER I MALLOL: Les aljames sarraïnes de la governació d'Oriola en el segle XIV, C.S.I.C., Barcelona, 1988; y, de la misma, Organització i defensa d' un territori fronterer. La Governació d'Oriola en el segle XIV, C.S.I.C., Barcelona, 1990.

56. D. BERNABE GIL: "Universidades y villas..."

57. M.T. FERRER I MALLOL: Les aljames..., pp. 8-9.

58. P. BELLOT: Anales..., II, p. 160.

59. Ibidem, II, p. 149; M.T. FERRER I MALLOL: Les aljames..., pp. 7-8.

60. G. ESCOLANO: Op. cit., VI, col. 51-52. Puede verse el documento en A. R.V.: Real Cancillería, reg. 657, ff. 144-146v. (cortesía de R. BALDAQUI ESCANDELL) y reg. 396 (cortesía de J.A. BARRIO BARRIO).

61. Sobre las donaciones de que fueron objeto y situación inmediata a la conquista, vid. P. BELLOT: Anales..., II, 179-184; J. TORRES FONTES: Repartimiento..., pàssim; M.T. FERRER I MALLOL: Les aljames..., pp. 7-10. La situación previa a las colonizaciones alfonsinas, en D. BERNABE GIL: "Sobre el origen territorial en los señoríos valencianos de colonización alfonsina", comunicación presentada en el Congreso Señorío y feudalismo en la península ibérica (ss. XII-XIX), Zaragoza, 1989, en prensa.

62. Vid. P. PLA ALBEROLA: "Los señoríos de jurisdicción civil en el derecho foral valenciano", Studia Histórica, VI, 1988, pp. 351-360.

63. D. BERNABE GIL: "Sobre el origen..."

64. D. BERNABE GIL: "Los Santàngel, señores alfonsinos. Aspectos de una colonización señorial en territorio realengo", LLuis de Santàngel i el seu temps, Ajuntament de Valencia, 1992, pp. 58-59.

65. Ibidem, pp. 57 y ss.

66. No he encontrado referencias documentales que la mencionen con anterioridad a 1491. En dicho año figura ya La Granja, conjuntamente con Albatera, Cox y La Daya, como lugares de señorío que tratan de evadir las sisas municipales debidas a Orihuela. A.M.O.: Contestador de 1491, ff. 10, 28.

67. D. BERNABE GIL: "Sobre los orígenes...".

68. D. BERNABE GIL: "La formación de un patrimonio valenciano en el Seicientos valenciano. El primer Marqués de Rafal", Revista de Historia Moderna, 5, 1986, pp. 26-32.

69. Ibidem, pp. 39-43.

70. A. GIL OLCINA y G. CANALES MARTINEZ: Residuos de propiedad señorial en España. Perduración y ocaso en el Bajo Segura, Instituto Juan Gil-Albert, Alicante, 1988, pp. 143-147.

71. J. MULLAN Y GARCIA-VARELA: "La ciudad y los señores. La crisis del realengo foral en el sur del Pais Valenciano", Estudis d'Història Contemporània del País Valencià, 1, 1980, pp. 80-87. 
72. A.M.O.: Contestador de 1691, ff. 258-258v. Los capítulos de población fueron suscritos ante el notario Cipriano Campos, el 7 de abril de 1691. Existe copia, que no he podido consultar, en el Archivo de los Marqueses del Bosch, en la ciudad de Alicante.

73. D. BERNABE GIL: Tierra y sociedad en el Bajo Segura (1700-1750), UniversidadCaja de Ahorros Provincial de Alicante, 1982, pp. 130-136, 206-216.

74. G. CANALES MARTINEZ: "Creación del señorío eclesiástico de Bigastro (16971715)", La propiedad de la tierra en España, Universidad de Alicante, 1981, pp. 65-73.

75. A. GIL OLCINA y G. CANALES MARTINEZ: "Creación, disolución y parcelación del señorío alfonsino de Daya Vieja”, Investigaciones Geográficas, 7, 1989, pp. 31-50.

76. J. MILLAN Y GARCIA-VARELA: Rentistas y campesinos. Desarrollo agrario y tradicionalismo político en el sur del Pais Valenciano (I680-1840), Instituto Juan Gil-Albert, Alicante, 1984, pp. 306-308.

77. Ibídem, pp. 103-112.

78. Sólo para la edad moderna pueden contabilizarse más de una docena de colonizaciones alfonsinas repartidas por los términos de Alicante, Alcoy-Jijona, Cocentaina, Gandía, Játiva, Alcira y Valencia. Referencias en los trabajos citados en supra, nota 4.

79. Según recuentos realizados a partir de padrones de regantes, en 1535 la huerta de Orihuela sobrepasaba las 10.000 hectáreas irrigadas (A.M.O.: Sig. I.248, elaboración propia); y en 1609 , con un máximo poblacional en torno a los 4.000 vecinos, se aproximaba a las 12.000 (D. BERNABE GIL: "La Vega Baja del Segura en vísperas de la expulsión de los moriscos: Estructura de la propiedad de la tierra", Estructuras y regímenes de tenencia de la tierra en España, Ministerio de Agricultura, Pesca y Alimentación, Madrid, 1987, pp. 61-74, donde se ofrece la distribución de la propiedad). A efectos comparativos, téngase en cuenta que en la huerta de Valencia se calculaban unas 10.300 hectáreas a mediados del XVII, prácticamente las mismas que a principios del XIX. Muy por detrás quedaban los restantes sistemas del Reino. Vid. la síntesis reciente de J. ROMERO GONZALEZ y T. PERIS ALBENTOSA: "Usos, distribució i control de l'aigua", en Geografia General del Paisos Catalans. Els rius i la vegetació, Barcelona, 1992, pp. 186-278.

80. A.C.A.: C.A.: leg. 872, doc. 67. A.M.O.: Sig. 1.061, ff. 13v-14. Al parecer, ya la había pretendido con anterioridad, en 1614, alegando, además de los servicios prestados, los perjuicios que le había ocasionado la expulsión de los moriscos. Vid. J. LALINDE ABADIA: La gobernación general en la Corona de Aragón, Institución Fernando el Católico, Zaragoza, 1963, p. 411.

81. A.C.A.: C.A.: leg. 619, doc. 14. A.H.0.: Sec. Gobernación, carpeta sin clasificar. En su alegación, mencionaba expresamente la concesión obtenida por Rosell.

82. D. BERNABE GIL: “La formación...", pp. 50-51.

83. A. C. A.: C.A.: leg. 891, doc. 81. A.M.O.: Sig. 1.061, f. 14. Solicitaba también una renta de 300 ducados sobre la recepta de la Baylía, tal como la había gozado su predecesor en el oficio. Entre los méritos alegados mencionaba, además de los años de servicio en la Gobernación - 14 años como Lugarteniente- y la Baylía -algo más de 4 como titular-, el haber levantado a su costa una compañía de soldados que embarcó en Alicante con rumbo a Barcelona, bajo el mando de su propio hijo, como capitán, y un sobrino, como alférez; ambos fallecidos en servicio de Su Magestad.

84. A.R.V.: Manaments i Empares, 1672, L. 1, m. 1, ff. 39-42.

85. A.C.A.: C.A. leg. 889 , doc. $212 ;$ leg. 659 , doc. 57 . En la relación de méritos incluía 
el levantamiento en 1630, a su costa, de una compañía de Infantería que él mismo capitaneó, para el sitio de Casale (Italia), donde asistió durante más de un año, gastando de su hacienda más de 4.000 ducados.

86. D. BERNABE GIL: "La formación...", pp. 32-39.

87. A.C.A.: C.A.: leg. 858 , doc. 4/19-25.

88. D. BERNABE GIL: “Los Santángel...”, p. 58.

89. A.M.O.: Contestador de 1607, ff. 91-93.

90. A.M.O.: Contestador de 1619, ff. 13-14.

91. J. MILLAN Y GARCIA-VARELA: Rentistas y campesinos...., pp. 103 $\neg 105$. Las primeras concesiones a Portillo, en A.M.O.: Contestador de 1684, ff. 50-50 v, 113-114.

92. Concretamente, con motivo de la fundación de Formentera en $1691 \mathrm{y}$, de forma generalizada, ante las pretensiones baronales del señor de Jacarilla en 1700 . Vid. infra, notas 194 y 278 .

93. Infra,

94. J. MILLAN Y GARCIA-VARELA: Rentistas y campesinos..., pp. 21-41.

95. J.B. VILAR RAMIREZ: "Moriscos granadinos en el sur valencianos", Estudis, 9, 1982, pp. 15-47; D. BERNABE GIL: "Orihuela y los moriscos en vísperas de su expulsión", Revista de Moros y Cristianos, Orihuela, 1981, 2 pp.

96. A.M.O.: Contestador de 1543, f. 447.

97. J. MULLAN Y GARCIA-VARELA: Rentistas y campesinos..., p. 57.

98. D. BERNABE GIL: Monarquía y patriciado urbano en Orihuela. $1445 \neg 1707$, Universidad-Caja de Ahorros Provincial de Alicante, 1990, pp. 41-44.

99. La profusa actividad de D. Jaume Rossell ha dejado huellas documentales abundantes, aunque muy dispersas. Vislumbraron el dinamismo de esta interesante figura, J. CASEY: "Irrigació i economia al Pais Valencià, 1589-1689", Primer Congreso de Historia del Pais Valenciano, Universidad de Valencia, 1976, III, pp. 287-288; y J. MILLAN Y GARCIAVARELA: Rentistas y campesinos..., pp. 96-97. Menciones dispersas en J.B. VILAR RAMIREZ: Orihuela, una ciudad valenciana en la España Moderna, Caja de Ahorros de Alicante y Murcia, Murcia, 1981, 3 vols.

100. D. BERNABE GIL: “La formación...", pp. 11-66.

101. Portillo había caido en desgracia ya en 1694 , lo que posiblemente influyó en la frustración del proyecto colonizador. A.C.A.: C.A. Leg. 657, doc. 16/3; A.M.O.: Contestador de 1694, ff. 216-217v. Sobre la influencia política de los asesores y, concretamente, del Dr. Domingo Ruiz, vid. D. BERNABE GIL: "Los juristas en la burocracia municipal. Asesores y abogados ordinarios de la ciudad de Orihuela en el siglo XVII", Homenatge al dr. Sebastià Garcia Martínez, Generalitat Valenciana, Valencia, 1988, II, pp. 133-145.

102. Vid. al respecto, P. PLA ALBEROLA: "Los señoríos de jurisdicción civil....", pp. 351-360.

103. A.R.V.: Real Audiencia. Procesos, S, 264.

104. R. GARCIA CARCEL: Cortes... de Carlos V, p. 202.

105. Los señores de ambas Dayas pertenecían aun a mediados del siglo XVI al mismo linaje: los Masquefa.

106. Entre otros, A.H.O.: Protocolos de Jacobo Montiel, 1589-97, inventario de 12-IV- 
1593; Protocolos de Joseph Martínez, 1617, arrendamiento de 14-XI-1617. También, A.M.O.: Amojonamiento de Callosa, 1582, f. 175v, donde un testigo especifica que "de les dos Dayes, la Daya Vella no es poble sino una casa".

107. Aparecen empadronadas 14 casas en 1513, 11 en 1542, 8 en 1559, 8 en 1571 (Vid. respectivamente, A.M.O.: Sig. 890, ff. 37-45v; Sig. 980, ff. 225-251v; Sig. 983, ff. 21-63v; J.A. RAMOS VIDAL: Demografía, economía y sociedad en la comarca del Bajo Segura durante el siglo XVIII, Caja de Ahorros de Alicante y Murcia, Alicante, 1980, p. 27). En 1609 el número de habitadores de Rojales que es posible identificar en diversas escrituras notariales alcanza como mínimo la quincena (A.H.O.: Protocolos de Cardona, 1606-1609)

108. Varios contratos de arrendamiento, aparcería y establecimiento en enfiteusis de tierras, casas y molinos de Rojales, en A.H.O.: Protocolos de Riera, 1612 y Protocolos de Riera, 1613. Breve descripción del "señorio" en Protocolos de Pedro Boltes, 1634-37, cartas matrimoniales de 15-XII-1636.

109. P. BELLOT: Anales..., II, p. 184.

110. Sobre las relaciones entre Guardamar y Orihuela vid. una reciente aproximación en C.A. MARTINEZ TEVA y J. GARCIA AMOROS: Concesión del título de Real Villa a Guardamar, Ayuntamiento de Guardamar, 1992.

111. A.M.O.: Contestador de 1611, f. 24. Se trataba de una concesión graciosa, sin reserva de ningún tipo de dominio.

112. A.M.O.: Sig. 2.226, f. 151 (el documento está fechado en 1572).

113. Figuran empadronados 5 vecinos en 1530,7 en 1536 y 1542, 6 en 1559,11 en 1564 y 1566,8 en 1571,11 en 1579,10 en 1585,7 en 1589,14 en 1590, 6 en 1595 (Padrones vecinales correspondientes, en A.M.O.: Sig. 890, ff. 37-45v; Sig. 981, ff. 113-150v; Sig. 980, ff. 225-251v; Sig. 983, ff. 21-63v; Sig. 891; Sig. 893; J.A. RAMOS VIDAL: Op. cit., p. 27).

114. A.H.O.: Sec, Gobernación, carpeta sin clasificar.

115. A.M.O.: Amojonamiento de Callosa, 1582, ff. 174-178.

116. P. BELLOT: Anales..., II, pp. 181-182.

117. A.H.O.: Sec. Gobernación, carpeta sin clasificar. Es copia de testamento realizado el 8-IX-1615 y publicado el 9-IX-1615 ante el notario Antoni Çapata.

118. D. BERNABE GIL: “La formación...”, pp. 39-43.

119. D. BERNABE GIL: "Sobre el origen...."

120. Vid. supra, nota 60.

121. G. ESCOLANO: Década primera..., lib. VI, col. 51-52.

122. Así lo comunicaba Bellot, desde su curato de Catral, a la ciudad de Orihuela, en carta de 1623, recordando al mismo tiempo la oposición urbana que tal concesión suscitó (A.M.O.: Contestador de 1623, f. 548).

123. Diversas fases del desarrollo del proceso y noticias complementarias, en A.M.O: Sig. 308, ff. 409-433; Contestador de 1602, ff. 448-456, 494; Albatera, 1601-1687, ff. 256 y ss.

124. E. CİSCAR PALLARÉS: Cortes... de 1604, p. 80.

125. A.M.O.: Contestador de 1613 , ff. $458 \mathrm{v}-459 \mathrm{v}$.

126. Ibídem, ff. 458-465, 477-477v; A.R.V.: Real Audiencia. Procesos, let. R, 107; Manament $i$ Empares 1613, L. 5, m. 53, ff. 11-16.

127. A.C.A.: C.A. Leg. 890, doc. 173. 
128. A.M.O.: Sig. 1.067 , ff. $177-182 v$.

129. A.M.O.: Contestador de 1690, ff. 163-163v.

130. A.M.O.: Contestador de 1567, ff. 87-87v.

131. A.H.O.: Protocolos de Cardona, 1606-1609, escrituras varias referentes a 1609. Sobre la población, vid. fuentes citadas en supra, notas 107 y 113.

132. Aunque las referencias al respecto son escasas. Cfr. J.A. BARRIO BARRIO: "El señorío de La Daya y el municipio de Orihuela en el siglo XV", comunicación presentada en el Congreso Señorío y Feudalismo en la Península Ibérica (siglos XII-XIX), Zaragoza, 1989, (en prensa); y J.B. VILAR RAMIREZ: La baronía de Daya Nueva. Aproximación a la historia rural del sur valenciano, Club Excelsior Daya Nueva, Alicante, 1992, pp. 40-58.

133. E. CISCAR PALLARES: Cortes... de 1604, p. 82. En uno de los privilegios aducidos, dado en 1330 , "se concedi lo mer y mixt imperi, y tota jurisdictio civil y criminal en dit lloch y terme de La Daya tam inter suos, quam inter extraneos ibidem delinquentes \& contrahentes".

134. Ibidem; P. BELLOT: Anales..., II, p. 160; M.T. FERRER I MALLOL: Les aljames..., pp. 8-9; J.B. VILAR RAMIREZ: La baronía..., pp. 59-60. La cita textual, en A.R.V.: Manament $i$ Empares, L. 5, m. 54, f. 1.

135. A.M.O.: Contestador de 1682, f. 273.

136. A.M.O.: Sig. 1.067, ff. 177-178v; Sig. 2.102, s.f.

137. A.M.O.: Contestador de 1690, ff. 163-163v.

138. A.C.A.: C.A. Leg. 718, doc. 72/14, cap. 14.

139. A.M.O.: Provisiones Reales, 1523-1617, ff. 422-422v;

140. Ibidem, ff. 423-423v.

141. A.M.O.: Contestador de 1617, f. 383-385v.

142. A.M.O.: Contestador de 1629, ff. 99-99v.

143. Ibidem, ff. 110.

144. Concretamente, en el capítulo 25 de dichos privilegios. Vid. referencias en D. BERNABE GIL: "Universidades y villas...".

145. En un trabajo, en curso, sobre la jurisdicción de aguas en el Bajo Segura durante el Antiguo Régimen, me ocupo más detenidamente de esta cuestión. Ejemplos varios del procedimiento a seguir cuando las denuncias sobre aguas eran realizadas por o contra un vasallo de señorío, en A.M.O.: Sig. 70, Sig. 72, Sig. 76, pàssim; entre otros.

146. A.C.A.: C.A.: Leg. 867, doc. 18; A.M.O.: Contestador de 1617, ff. 437-438.

147. Sobre el carácter fundamental de las disputas entre los regantes de aguas arriba subirans- y aguas abajo -jussans-, en otros sistemas de riego valencianos, vid. T.F. GLICK: Regadio y sociedad en la Valencia medieval, Del Cenia al Segura, Valencia, 1988, pp. 67131; T. PERIS ALBENTOSA: "Conflictividad y administración de justicia en la Acequia Real de Alcira", Dels Furs a l'Estatut. Actes del I Congrés d'Administració Valenciana: de la història a la modernitat, I.V.A.P., Valencia, 1992, pp.; y, del mismo: Regadio, producción y poder en la Ribera del Xúquer, Confederación Hidrográfica del Júcar-Generalitat Valenciana, Valencia, 1992, pp. 260-277.

148. A.M.O.: Sig. 76, ff. 121v-127.

149. A.M.O.: Contestador de 1617, ff. 437-438. 
150. A.C.A.: C.A.: Leg. 659, doc. 57/1.

151. A.M.O.: Sig. 1.415, ff. 171-187.

152. Ibidem, copia de la sentencia de 1628, entre Callosa y Catral, en ff. 180-187.

153. La sentencia del sobrecequiero de Orihuela, de 1641, fue conforme a la de la Audiencia, de 1618, y, en consecuencia, contraria a las pretensiones del señor de Cox. No hay noticia de que se apelara posteriormente ante los tribunales reales (Ibidem).

154. A.M.O.: Sig. 69, ff. 255-258.

155. A.J.P.A.A.A.: Lib. 3, ff. $48 \mathrm{v}-50$.

156. A.C.A.: C.A. Leg. 856, doc. $28 / 33$.

157. Sobre la visita de las aguas por Mingot, cuya valoración no es éste el momento de abordar -por su complejidad y por ocupar un lugar secundario respecto al tema central que nos ocupa-, vid. A.C.A.: C.A.: Leg. 615, doc. 4/1-78. Los estatutos fueron publicados, en traducción castellana y acompañados de breve introducción, por A. NIETO FERNANDEZ: Estatutos de Riegos del Juzgado Privativo de Aguas de Rojales, Caja Rural de Orihuela, s.a. Varios procesos sustanciados ante Mingot, en A.M.O.: Sign. 69 y Sign. 77

158. A.C.A.: C.A.: Leg. 711, doc. 25; Leg. 879, doc. 160.

159. A. C. A.: C. A. Leg. 856, doc. 28.

160. Los privilegios mencionados, en A.M.O.: Amojonamiento de Callosa, 1582, ff. 620; y A.R.V.: Real, 357, ff. 81v-98v; respectivamente. En el contexto regnícola, vid. D. BERNABE GIL: "Universidades y villas...", p. 19.

161. Desde luego, con anterioridad a la sentencia real de 1439 que sancionó el tipo de vinculación jurisdiccional (transcripción en C.A. MARTINEZ TEVA y J. GARCIA AMOROS: Concesión del título..., pp. 26-30), tal como se expresa claramente en los capítulos de arrendamiento de la sisa mayor ya en 1401 (Cit. por J.A. BARRIO BARRIO: El ejercicio del poder en un municipio medieval: Orihuela 1308-1479, tesis doctoral, Universidad de Alicante, 1993, II, f. 550).

162. P. BELLOT: Anales..., II. p. 162.

163. Ibidem, II, pp. 151, 154.

164. A.M.O.: Contestador de 1491, ff. 17, 29, 48v.

165. A.M.O.: Ibídem, f. 29.

166. Ibídem, f. 17.

167. Contestador de 1499 , ff. $48 \mathrm{v}, 49 \mathrm{v}$.

168. Así se afirma en 1491 (A.M.O.: Contestador de 1491, f. 34). En el padrón más próximo, de 1530, se contabilizan 130 casas (A.M.O.: Sig. 981, ff. 46-106).'

169. A.M.O.: Contestador de 1491 , f. 17.

170. Así parece deducirse de la inexistencia de noticias sobre el particular y de la significativa desaparición de los señoríos, pero no de los lugares realengos aun dependientes de la ciudad, en los padrones de sal y muro conservados a partir de 1566 (A.M.O.: Sig. 890 y Sig. 891).

171. Sobre la forma de recaudar el muro en el siglo XVII, vid. D. BERNABE GIL: Hacienda y mercado urbano en la Orihuela foral moderna, Instituto Juan Gil-Albert, Alicante, 1989 , p. 70.

172. J. HINOJOSA MONTALVO y J.A. BARRIO BARRIO: "Las sisas en la Gobemación de Orihuela durante la baja Edad Media" Anuario de Estudios Medievales, 22, 1992, pp. 535-579; D. BERNABE GIL: Hacienda y mercado..., pp. 119-131. 
173. Así, la exención de ciertos derechos del Real Patrimonio, como peytas, morabatí, coronaje, maridaje, cenas, almojarife, etc., otorgada a la ciudad, se extendía en realidad a todos sus términos generales.

174. P. BELLOT: Anales..., II, pp. 151-152, 122. El derecho de tall del drap, perteneciente a la Diputación del General del Reino, había quedado encabezado a perpetuidad en toda la contribución general oriolana en una cuantía anual fija que se encargó de asumir directamente la hacienda municipal urbana con cargo a sus rentas ordinarias. De este modo, se eximía la actividad gravada en origen -la confección de tejidos para su venta- y se hacía recaer el impuesto sobre las fuentes ordinarias de ingresos (D. BERNABE GIL: Hacienda y mercado..., pp. 69-70). No ha de extrañar, por tanto, que en determinadas ocasiones llegara a trasladarse directamente la obligación de pago al arrendatario de la sisa mayor, como ha detectado J.A. BARRIO BARRIO (El ejercicio del poder..., II, f. 566).

175. J.A. BARRIO BARRIO: "El señorío de La Daya...".

176. A.M.O.: Contestador de 1491, f. 28. Tal fue, en efecto, la razón aducida para explicar el incremento poblacional y, en consecuencia, del consumo.

177. Ibidem, ff. 10-10v.

178. Ibidem, ff. $10 \mathrm{v}, 25,28$.

179. A.M.O.: Contestador de 1549, ff. 79-80, 84-84v, 88; Sig. 2.216, ff. 130-197; Contestador de 1550, ff. 26-38. La información que sigue procede de estas tres fuentes.

180. A.M.O.: Sign. 2.218 , ff. 359-371.

181. A.M.O.: Sig. 308, ff. 163-194, 325-337; Procesos 1600-1619, ff. 1-31; Contestador de 1607, ff. 445-445v, 459-459v. La información que sigue procede de estas fuentes.

182. Según parece desprenderse de J. HINOJOSA MONTALVO y J.A. BARRIO BARRIO: "Las sisas en la Gobernación...", pp. 551-555.

183. D. BERNABE GIL: Hacienda y mercado..., pp. 24-25, 119-128.

184. Ibidem, p. 122; A.M.O.: Contestador de 1593, f. 590; Contestador de 1596, f. 436 436v, 450; Contestador de 1597, ff. 452-452v.

185. D. BERNABE GIL: Hacienda y mercado..., p. 122.

186. A.R.V.: Real Audiencia. Procesos, S, 1.109; A.M.O.: Sig. 2.277, ff. 350-360; Contestador de 1602, f. 452; Contestador de 1603, ff. 505-505v, 532, 534v.

187. D. BERNABE GIL: Hacienda y mercado..., p. 122.

188. A.R.V.: Real Audiencia. Procesos, R, 115. A.M.O.: Sig. 2.260. Procesos 16151616, ff. 256-281; Clavaría 1619-1620, sin fol.

189. D. BERNABE GIL: Hacienda y mercado..., p. 122 y ss.

190. A.M.O.: Clavaria de 1626, sin fol.

191. D. BERNABE GIL: Hacienda y mercado..., pp. 121-127.

192. A.M.O.: Clavaria de 1637, sin fol.

193. A.M.O.: Contestador de 1666, ff. 167, 214-214v.

194. A.M.O.: Clavaría de 1675, sin fol.

195. A.M.O.: Contestador de 1691, ff. 258-258v.

196. Las exacciones señoriales no agrarias derivaban fundamentalmente de la explotación monopolista de los servicios públicos -regalías de horno, panadería, taberna, molino, etc.-, pues las sisas pertenecían a la universitat de vasallos, aunque el señor tuviera que autorizar su imposición. 
197. Quejas en este sentido, en A.M.O.: Contestador de 1699, ff. 416v-417; Contestador de 1702, f. 215. En el primer caso se denunciaba la introducción de carne adquirida en Redován; en el segundo, en Molins.

198. D. BERNABE GIL: Hacienda y mercado..., pp. 192-266.

199. Vid. supra, nota 160.

200. Ejemplos de ello, en A.M.O.: Sig. 2.237, ff. 207-216. Las diferencias de esta práctica con respecto a la habitual antes de la segregación, en Contestador de 1571, ff. 150 y ss.; Contestador de 1578, ff. 5, 26; Contestador de 1581, ff. 168 $\neg 168 \mathrm{v}, 170$.

201. Las noticias, para época medieval, en P. BELLOT: Anales..., II, 155, 161; J. A. BARRIO BARRIO: "El señorío..."; J. B. VILAR: La baronía..., p. 175. Para época moderna, infra.

202. A.M.O.: Sig. 2.237, ff. 207-216; Contestador de 1593, ff. 668-668v.

203. A.M.O.: Contestador de 1571, ff. 72, 74, 77v-82v. En un principio, la Audiencia inhibió a las autoridades oriolanas en sus actuaciones acerca del trigo del señor de la heredad de Daya Vieja. El problema se complicó, no obstante, porque el trigo objeto de secuestro 150 cahices- pertenecía, en realidad, a los dos arrendatarios de la heredad y no al señor.

204. La distribución del dominio útil en los señoríos, en D. BERNABE GIL: "La Vega Baja...". Referencias al escaso protagonismo del trigo entre los moriscos de los señoríos, en comparación con la alcanzada por otros granos, en A.M.O.: Sig. 2.277, ff. 355, donde las dos partes enfrentadas en un litigio -la ciudad y el arrendatario de la sisa de la molienda- coincidían, en enero de 1610, al menos en una apreciación: "los morischs que habitaven en los llochs de Coix, Granja, Albatera y Benejússer y Redovà tenien de costum sustentarse ab dacsa, ordi, panis y altres pans menuts y gastaven molt poch forment".

205. La referencia de 1435, en P. BELLOT: Anales..., II, p. 155. La de 1508, en A.M.O.: Contestador de 1602, f. 455.

206. A.M.O.: Contestador de 1572, f. 524.

207. A.M.O.: Sig. 2.237, ff. 207-216;

208. A.M.O.: Contestador de 1572, f. 524.

209. A.M.O.: Procesos, 1600-1619, ff. 219-225; Contestador de 1614, f. 133.

210. A.M.O.: Contestador de 1593, f. 74.

211. A.M.O.; Contestador de 1596, ff. 436-436v; Contestador de 1602, f. 452.

212. Vid. supra, Parte Primera, para el planteamiento general y disposiciones forales que se mencionan.

213. P. BELLOT: Anales..., II, p. 150.

214. Ibídem, II, pp. 151, 153.

215. Ibídem, II, pp. 162, 165, 167.

216. Ibídem, II, pp. 161, 162.

217. Sobre la concesión de vedado al titular de Benijófar, y confirmaciones posteriores, A.C.A.: C. A. Leg. 886, doc. 6/2. Ese mismo año de 1459 se concedieron en realidad dos privilegios de dehesa sobre sendas heredades, según menciona J.A. BARRIO BARRIO: "El señorío...". Por su ubicación es casi seguro que se trataba de Benijófar y de la Juliana.

218. Objeto de antigua donación a favor de la Orden Militar de Santiago, Algorfa comprendía, amén de la tierra cultivada, "tots los amprius y señoría que la dita heretat té ad aque- 
lla contiguos" (A.H.O.: Gobernación, carpeta sin clasificar, traslado de escritura de inventario, de 4-VIII-1546, ante el notario Francisco Vilanova). Escrituras de arrendamiento de la dehesa de Algorfa, en A.H.O.: Protocolos de Salvador Loazes, escritura de 9-I -1494; Protocolos de Ginés López, escritura de 10-V-1603. No hay constancia de que Orihuela reclamara ante los tribunales derechos vecinales de amprius.

219. El principal recurso de los amprius de Daya Vieja consistía en la sosa de sus saladares, cuya recolección solía arrendar su titular. Escrituras al respecto, en A.H.O.: Protocolos de Pedro Camps, escr. de 5-III-1602; Protocolos de Cardona, escr. de 31-III-1609; Protocolos de Joan Leon, escr. de 9-III-1635 y 30-VIII $\neg$ 1635. No hay constancia de que Orihuela plantease ante los tribunales derechos vecinales de amprius.

220. Sobre el origen de la cañada adehesada o vedada de Roca de Togores, A.M.O.: Sig. 2.237 , ff. 318-320. En un documento muy posterior -1590- se llega a denominar a dicha dehesa, de forma desconcertante, como "baronía" (Sig. 2.244, f. 54). El número de cañadas con título de dehesa no debió ser muy elevado, pues aunque en 1535 se citaron a comparecer ante la Real Audiencia a más de una veintena de "senyors de canyades" -incluidos los señores de vasallos- en el término general de Orihuela, no todos debían tener privilegio de vedado, segun parece deducirse de noticias posteriores. A.M.O.: Sig. 2.212, ff. 67-71.

221. D. BERNABE GIL: "Los Santàngel...", pp. 59, 64.

222. A.M.O.: Contestador de 1491, ff. 58-58v.

223. A.M.O.: Amojonamiento de Callosa, 1582, ff. 338-338v.

224. A.M.O.: Sig. 2.25I, ff. 216-219.

225. A.M.O.: Contestador de 1491 , ff. $56,59$.

226. A.M.O.: Sig. 2.212, ff. 86-87.

227. A.C.A.: C.A. Leg. 888 , doc. $6 / 2$.

228. A.M.O.: Sig. 2.212, ff. 87-93.

229. Ibidem, ff. $60-66,67-79 \mathrm{v}, 85$.

230. Ibídem, f. 296.

231. A.M.O.: Contestador de 1564, ff. 84-89v. La reasignación -pues hay noticia de asignaciones anteriores- era como sigue: "Primo que los bovalars se entenguen e sien del Estret vulgarment dit de Soler fins al port de $\mathrm{Na}$ Ginesa, e del dit port fins al cabeço y lloma que està en front de la lloma e cabeço del Palomar. E de alli fins al port que.s diu de Sancho Navarro y ara se diu de (en blanco) enves la present Ciutat y de alli envés lo mont e envés la mar que reste segons avall serà declarat.

"Item aximateix assignen per redonda per als bestiars de la dita Ciutat la Redonda que antigament fonch assignada per lo magnifich Consell, ço es, de les Cotiendes e vertents de la balsa de la Xinella a la escalerola que.s diu de Pere Roiz y ara se diu de Juan Loazes, e al alcor. E de alli al cabeço que.s diu del Mortero. Y a la sima de les Çafurdes, y a la rambla del $\mathrm{Pi}$, e al estany de les Salines y de alli a la lloma de Algorfa.

"Item en la partida de Escorratell assignen en bovalars aixi mateix los que antigament tenia e té lo dit Consell assignats. ço es, del barranch de la Figuera al llozar y de alli a la vereda del LLongo, y aixi com va la dita vereda envés la dita Ciutat".

A continuación se establecían una veintena de capítulos con las limitaciones y prohibiciones vecinales en el uso de los amprius, cuya vigilancia estaba encomendada al caballero de la sierra. 
232. A.M.O.: Contestador de 1491, ff. 58-58v.

233. El amojonamiento general de los boalares oriolanos, en 1550 , se realizó por orden del Regente de la Lugartenencia General en el Reino de Valencia, D. Jerónimo Cabanilles, a instancia de ciertos ganaderos. En la orden se expresaba "que los bovalars de aquella no estan senyalats, fitats e amollonats, de hon facilment los cabañers e pastors se poden enganyar en dits bovalars y encara per vosaltres sería consentit que per alguns particulars fossen fets àrrendaments de algunes parts de dits bovalars contra forma e disposició de furs, ordenacions e stabliments antichs". A.M.O.: Contestador de 1550, ff. 285-292, donde se incluye relación de los 17 mojones. El tercer mojón, concretamente, fue mandado levantar delante del barranco de la Higuera, entre otros dos barrancos, antes de llegar a la cañada de Jacarilla, caminando en dirección a poniente. La noticia sobre la sentencia relativa al amojonamiento de Jacarilla, dada el 16-XII-1549, en A.M.O.: Sig. 2.228, f. 7.

234. A.M.O.: Contestador de 1567, ff. 208-210v; Sig. 2.228, ff. 5-11.

235. A.M.O.: Contestador de 1567, ff. 81-82.

236. D. BERNABE GIL: "Los Santàngel...", p. 64.

237. A. M. O.: Contestador de 1593, f. 57.

238. A. M. O.: Contestador de 1599, ff. 129-129v.

239. A.M.O.: Contestador de 1607, ff. 30v, 148.

240. A.M.O.: Amojonamiento de Callosa, 1582, f. 12v; A.R.V.: Real, 357, f. 88v.

241. A.C.A.: C.A. Leg. 775, doc. 7. La oposición de la ciudad al estatuto en cuestión, en A.M.O.: Contestador de 1569, ff. 25-27.

242. A.C.A.: C.A.: Leg. 775, doc. 7, cap. 31. También, L. OCAÑA: LLibre de capitols ab los quals se arrenden y collecten los drets Reals que te Sa Magestat en la Governacio y Batlia general de Oriola y Alacant, ab les declaracions de com se executen y practiquen, Imp. Augustí Martinez, Oriola, 1613, ff. 150-152.

243. A.C.A.: C.A.: Leg. 775 , doc. 7.

244. A.M.O.: Amojonamiento de Callosa, 1582, ff. $287 \mathrm{v}-291$.

245. Ibidem, ff. $87 v-88$.

246. Cit. por J. MILLAN Y GARCIA-VARELA: Rentistas y campesinos..., p. 117.

247. A.M.O.: Amojonamiento de Callosa, 1582, ff. $297 \mathrm{v}-304 \mathrm{v}$.

248. A.M.O.: Sig. 2.237, ff. 318-320.

249. A.M.O.: Contestador de 1593, ff. $4-4 \mathrm{v}$.

250. A.M.O.: Sig. 2.251 , ff. 168-238.

251. A.M.O.: Contestador de 1607, f. 467.

252. A.M.O.: Provisiones Reales, 1523-1617, f. 384.

253. Cit. en J. MILLAN Y GARCIA-VARELA: Rentistas y campesinos..., p. 96.

254. A. C. A.: C. A Leg. 653, doc. 21/3.

255. La Rambla de la Somada figura entre los bienes objeto de la primera vinculación instituída por el Señor de Benejúzar, en 1630 (A.H.O.: Protocolos de Damián León, cartas matrimoniales de 24-VII-1633). A veces, se la denomina únicamente como heredad de Rambla; así, en los contratos de arrendamiento suscritos en $1640,1668,1673$ y 1675 (Protocolos de Alonso Rodriguez, escritura de 3-XII-1640; Protocolos de Ginés Amorós, escrituras de 14-V-1668, 27-V-1673, y 26-VII-1675), sin mención expresa en ninguno de ellos al tema de las hierbas. 
256. A.M.O.: Contestador de 1660, ff. 20-21v.

257. A.M.O.: Sign. 2.125, sin fol.

258. A.M.O.: Contestador de 1663, ff. $240-240 \mathrm{v}$.

259. Ibidem.

260. A.H.O.: Gobernación, carpeta sin clasificar.

261. A.M.O.: Sign. 2.212, f. $61 \mathrm{v}$.

262. A.M.O.: Amojonamiento de 1582, ff. 101, 237 y ss.

263. D. BERNABE GIL: "Los Santàngel...", p. 66.

264. Ibidem, pèssim.

265. A.M.O.: Contestador de 1573, ff. 22-24, 156.

266. A.M.O.: Contestador de 1578, ff. 78-79.

267. A.H.O.: Gobernación, carpeta sin clasificar.

268. A.M.O.: Albatera, 1601-1687, ff. 234v-235.

269. Ibídem, pàssim; A.M.O.: Sig. 2.102. 1611-1809, ff. 148-167.

270. Texto de la sentencia en A.M.O.: Albatera, 1601-1687, ff. 243-253.

271. Vid., sobre estas compensaciones, J.R. TORRES MORERA: Repoblación del Reino de Valencia después de la expulsión de los moriscos, Valencia, 1969, pp. 143-146.

272. A.M.O.: Contestador de 1623, ff. 548-548v.

273. A.M.O.: Contestador de 1643, ff. 60v-62.

274. A.M.O.: Contestador de 1693, ff. 217, 311.

275. Ha estudiado el pleito, J. MILLAN Y GARCIA-VARELA: "La ciudad y los señores. La crisis del realengo foral en el sur del Pais Valenciano", Estudis d'Història Contemporània del Pais Valencià, 2, 1981, pp. 61-98.

276. A.H.O.: Gobernación, carpeta sin clasificar; Protocolos de Joseph Martinez de Rodríguez, 1726, ff. 285-285v.

277. A.M.O.: Sig. 1.067. 1681-1698, ff. 159-160v, 174-176v, 348; Contestador de 1692 , ff. $200-202,253-254 \mathrm{v} 263 \mathrm{v}-264,274,284-284 \mathrm{v}$.

278. A.C.A.: C.A. Leg. 858 , doc. $4 / 19$.

279. A.M.O.: Contestador de 1692, f. 200.

280. A.C.A.: C.A. Leg. 858, doc. 4/23-25.

281. Se trataba de las hierbas de una heredad ubicada en la partida de campo de Las Salinas. A.M.O.: Contestador de 1680, ff. 253-254; Contestador de 1681, ff. 259v-261; Contestador de 1682, ff. 137-138.

282. D. BERNABE GIL: "La formación....", pp. 37-38.

283. J. MILLAN Y GARCIA-VARELA: Rentistas y campesinos..., pp. 118.

284. A.M.O.: Contestador de 1702, ff. 6-6v; 33-34.

285. Ibidem, f. 239.

286. A. PARDO Y MANUEL DE VILLENA (MARQUES DE RAFAL): EI Marqués de Rafal y el levantamiento de Orihuela en la Guerra de Sucesión (1706), Madrid, 1910; J. MILLAN Y GARCIA-VARELA: Rentistas y campesinos..., pp. 126-132. 
287. A.M.O.: Libro Capitular de 1704, ff. 216-216v.

288. A.M.O.: Amojonamiento de 1582, ff. 297v-304v.

289. J. MILLAN Y GARCIA-VARELA: Rentistas y campesinos..., p. 119, nota 71.

290. D. BERNABE GIL: "Sobre el origen territorial...".

291. D. BERNABE GIL: "Las oligarquías urbanas del Reino de Valencia en el tránsito a la Edad Moderna", Congreso El Mediterráneo europeo y las ciudades en el tránsito de los siglos $X V$ y $X V I$, Alicante, 1990, (en prensa). En el caso de Orihuela, simultanearon su condición de señores y caballeros insaculados para los oficios municipales, con anterioridad a 1656 -en que se abre la posibilidad de hacerlo a la nobleza-, el barón de Daya Nueva, los señores alfonsinos de Cox y La Granja, y los de hipotética jurisdicción civil -previamente a su posterior colonización alfonsina- de Benejúzar, Benferri, Rafal, Jacarilla y Daya Vieja.

292. Vid. supra, p. 16. En general, J. CASEY: El Regne de Valencia al segle XVII, Curial, Barcelona, 1981, cap. 8. Si puede servir de ejemplo, en Orihuela gran parte de los cargos de Lugarteniente de Gobernador -LLochtinent de Portantveus de General Governador ultra Sexona- fueron ocupados durante el siglo XVII, de manera sucesiva, por los señores de Rafal, Cox, Benferri, Jacarilla y Benejúzar -con presencia estos últimos, además, en la Baylía General de la misma demarcación-; mientras que el Conde de Albatera y barón de Daya Nueva llegó a formar parte del Consejo de Aragón. 